Universidade de Brasília

Faculdade UnB Planaltina

Programa de Pós-Graduação em Gestão Pública

Mestrado Profissional em Gestão Pública

IONE DOS SANTOS VELAME

\title{
ECONOMICIDADE E EFICIÊNCIA TEMPORAL ESTUDO DE CASO NO INSTITUTO FEDERAL DE GOIÁS
}

Brasília - DF

2016 
IONE DOS SANTOS VELAME

\section{ECONOMICIDADE E EFICIÊNCIA TEMPORAL ESTUDO DE CASO NO INSTITUTO FEDERAL DE GOIÁS}

Dissertação de Mestrado apresentada ao Programa de Pós-Graduação de Gestão Pública da Faculdade UnB de Planaltina (FUP) como requisito para obtenção do título de mestre em Gestão Pública, área de concentração: Gestão Pública e Territórios.

Orientador: Prof. Dr. André Nunes

Brasília-DF

2016 
Velame, Ione dos Santos.

Economicidade e Eficiência Temporal: Estudo de caso no Instituto Federal de Goiás / Ione dos Santos Velame - Brasília, 2016.

79 f. : il.

Dissertação (Mestrado) - Faculdade UnB de Planaltina, Programa de Pós-Graduação em Gestão Pública, 2016.

Orientador: Prof. Dr. André Nunes, Programa de Pós-Graduação em Gestão Pública.

1. Contratações Públicas. 2. Pregão Eletrônico. 3. Economicidade e Eficiência. I. Título. 
IONE DOS SANTOS VELAME

\section{ECONOMICIDADE E EFICIÊNCIA TEMPORAL ESTUDO DE CASO NO INSTITUTO FEDERAL DE GOIÁS}

Dissertação aprovada como requisito para a obtenção do título de Mestre em Gestão Pública do Programa de Pós-Graduação em Gestão Pública da Faculdade UnB de Planaltina (PPGP/FUP). A Comissão Examinadora foi formada pelos professores:

Dr, Alexandre Nascimento de Almeida Professor-Examinador - Membro Interno
Dr, Tito Belchior Silva Moreira Professor-Examinador- Membro Externo

Brasília, 15 de fevereiro de 2016. 


\section{AGRADECIMENTOS}

A realização do presente trabalho, marca o final de uma etapa do meu percurso acadêmico, e como tal, não poderia deixar de dirigir algumas palavras de agradecimentos a todos aqueles que me incentivaram a lutar por aquilo que sempre acreditei e que me ajudaram a realizá-lo. Agradeço inicialmente a Deus por me capacitar e permitir seguir em frente, superando o emocional. À Mainha "Dona" Iraildes, que sempre esteve junto, mesmo que longe, estimulando as minhas escolhas. À minha família, meu esposo Christiano e meus filhos Lipe e Dudu, meus grandes amores e companheiros de todos os momentos, inclusive das minhas ausências. Aos amigos, em especial aos do PPGP que me apoiaram durante este percurso fazendo com que esse sonho seja uma realidade. Não poderia deixar de agradecer o Professor/Orientador Dr. André Nunes pela sua capacidade intelectual e simplicidade, auxiliando-me, de maneira grandiosa, na elaboração deste trabalho. Soulhe muito grata por este gesto de carinho e dedicação que, em certa medida, transformou me numa

outra pessoa. A todos que contribuíram direta ou indiretamente, para esse objetivo tornar-se realidade, o mais sincero obrigado! 
Se vi mais longe foi por estar de pé sobre ombros de gigantes.

Isaac Newton 


\title{
RESUMO
}

O objeto de estudo deste trabalho é o aperfeiçoamento da gestão dos recursos públicos, que, na atual conjuntura fiscal, deve primar pela economicidade e qualidade dos serviços. A Administração Pública Brasileira tem registrado avanços no sentido de imprimir melhorias de qualidade no setor público. Especificamente no que se refere a compras públicas o modelo de pregão e compras compartilhadas tem obtido resultados que merecem ser estudados. A presente pesquisa analisou as despesas nos processos de compras públicas, na modalidade Pregão Eletrônico com vistas a analisar comparativamente as contratações realizadas nos Institutos Federais da Região Centro Oeste do Brasil, no que tange os indicadores: economicidade e a eficiência temporal. Construiu-se uma pesquisa descritiva, com abordagem qualitativa, em que o universo analisado foram as despesas efetuadas no ano de 2014 nos Institutos Federais de Educação da Região Centro Oeste. Os resultados obtidos demonstraram que a utilização do pregão eletrônico e das compras compartilhadas produz ganhos significativos no indicador economicidade em todas as instituições pesquisadas. Os resultados para o indicador de eficiência temporal revelaram grande assimetria entre as instituições, apontando para um diferencial de mais de três vezes entre os Institutos Federais.

Palavras chave: Contratações Públicas, Pregão Eletrônico, Economicidade e Eficiência Temporal.

\begin{abstract}
The study object of this work is the improvement of the public resources management, which, in the current fiscal situation, should strive for economicity and quality of services. The Brazilian Public Administration has registered progress towards producing quality improvements in the public sector. Specifically with regard to the public procurement, the model of trading and shared procurement has achieved results that deserve to be studied. This research examined the spending in public procurement processes, in Electronic Auction mode, in order to analyze comparatively the signings made in the Federal Institutes of west central region of Brazil, regarding the indicators economicity and time efficiency. A descriptive research was conducted, with qualitative approach, in which the universe analyzed were the expenses incurred in 2014 in the Institutes Federal of Central West Region. The results showed that the use of Electronic Auction and shared procurement produces significant gains in economic efficiency indicator in all the surveyed institutions. Results for the temporal efficiency indicator revealed wide variation between institutions, pointing to a gap of more than three times in relation to the Federal Institutes.
\end{abstract}

Keywords: Government Contracting, Electronic Auction, Economicity and Time Efficiency. 


\section{LISTA DE QUADROS}

Quadro 1: Estruturas de Módulos e Funcionalidades do SIASG..................................... 


\section{LISTA DE ILUSTRAÇÕES}

Tabela 1: Escala de Economia............................................................................ 45

Tabela 2: Evolução das contratações públicas do Poder Executivo Federal..................... 51

Tabela 3: Volume de compras por Instituição Federal de Ensino................................. 52

Tabela 4: Quantidade de processos de compras por modalidade................................... 53

Tabela 5: Escala de Economia por processo.............................................................. 57 


\section{LISTA DE FIGURAS}

Figura 1: Delineamento da pesquisa......................................................................... 50 


\section{LISTA DE GRÁFICOS}

Gráfico 1: Despesas com materiais e serviços em 2014............................................ 54

Gráfico 2: Economia nas aquisições de materiais e serviços em 2014.......................... 55

Gráfico 3: Eficiência Temporal: Tempo médio gasto na compra.................................. 56 


\section{LISTA DE SIGLAS}

CATMAT - Catálogo de Materiais

CATSER - Catálogo de Serviços

CEFET - Centro Federal de Educação Tecnológica

CF - Constituição Federal

CGU - Controladoria Geral da União

CPS - Compras Públicas Sustentáveis

EITs - Escolas Industriais e Técnicas

IFB - Instituto Federal de Brasília

IFEs - Instituições Federais de Ensino

IFG - Instituto Federal de Goiás

IF Goiano - Instituto Federal de Goiano

IFMS - Instituto Federal do Mato Grosso do Sul

IFMT - Instituto Federal de Mato Grosso

IRP - Intenção de Registro de Preços

LOA - Lei Orçamentária Anual

MPOG - Ministério do Planejamento, Orçamento e Gestão

PRONATEC - Programa Nacional de Ensino Técnico e Emprego

SIAFI - Sistema de Administração Financeira

SIASG - Sistema Integrado de Administração de Serviços Gerais

SICAF - Sistema de Cadastramento Unificado de Fornecedores

SICON - Sistema de Gestão de Contratos

SIDEC - Sistema de Divulgação Eletrônica de Compras

SISME - Sistema de Minuta de Empenho

SISPP - Sistema de Preços Praticados

SRP - Sistema de Registro de Preços

TCU - Tribunal de Contas da União 


\section{SUMÁRIO}

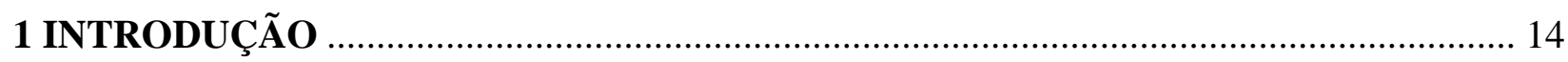

1.1 Formulação do Problema de Pesquisa .......................................................................... 17

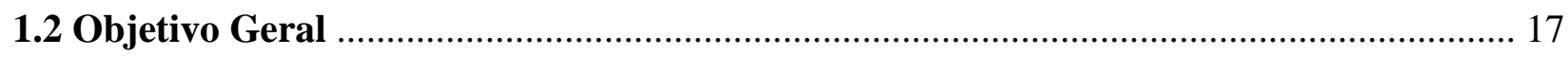

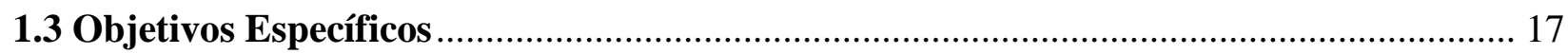

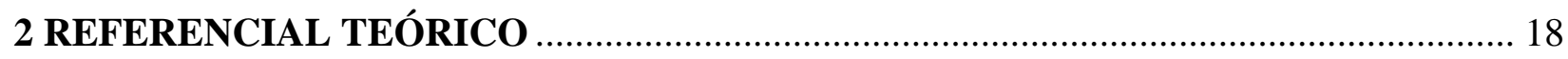

2.1. Princípios Norteadores da Administração Pública ............................................... 18

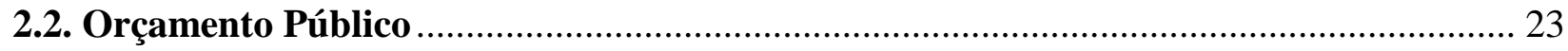

2.2.1. Princípios Básicos do Orçamento Público ................................................................. 25

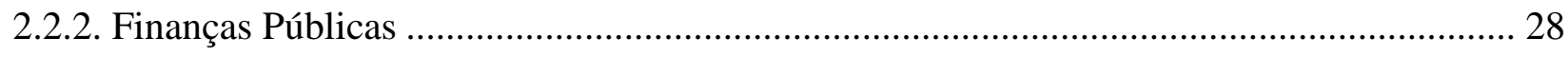

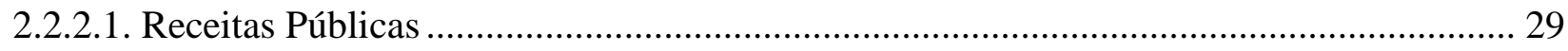

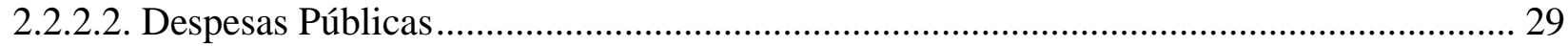

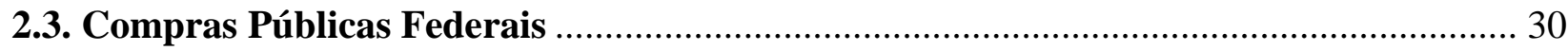

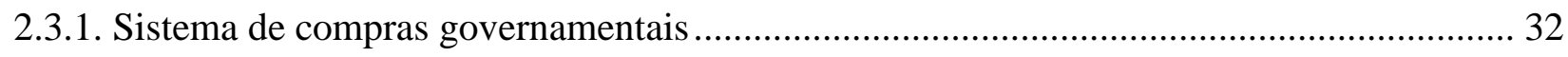

2.3.2. Licitações no Brasil como instrumento de políticas públicas........................................... 36

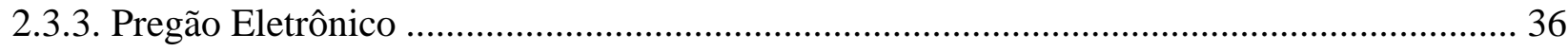

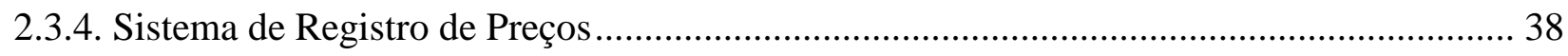

2.3.4.1. Adesão a Atas de Registro de Preços - Figura do Carona ........................................... 41

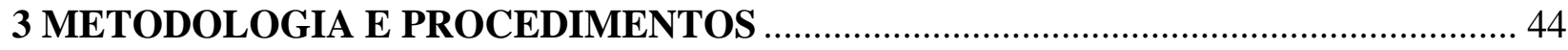

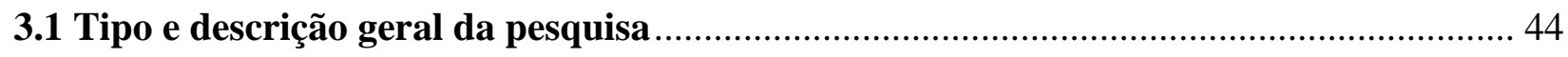

3.2 - Caracterização das Instituições analisadas......................................................... 46

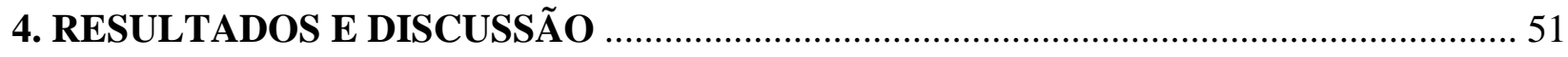

4.1 Contratações dos Órgãos do Poder Executivo Federal no período de 2010 a 2014. ....... 51

4.2 Contratações dos Institutos Federais de Educação, Ciência e Tecnologia da Região

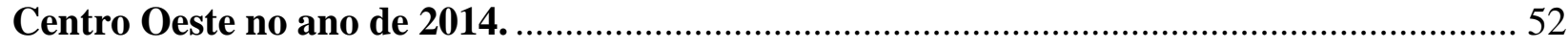

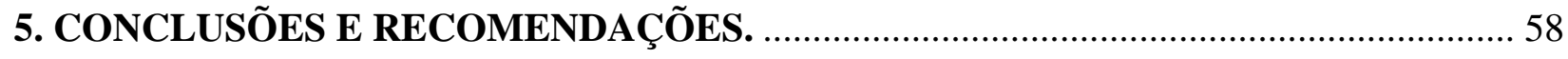

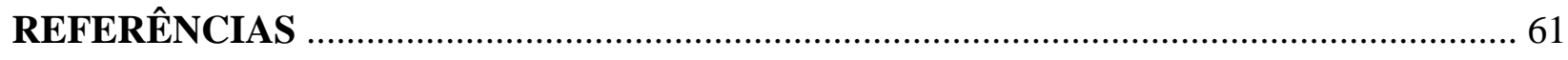

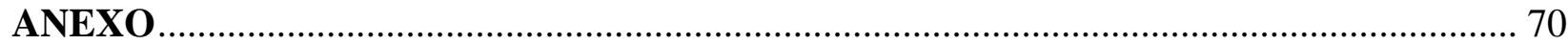




\section{INTRODUÇÃO}

O aperfeiçoamento da gestão dos recursos públicos é imprescindível para a produção de resultados satisfatórios, primando pela economicidade e qualidade dos serviços prestados pela administração pública à população. A obtenção de um serviço público de qualidade com valores de eficiência e eficácia é um desafio, particularmente no que se diz respeito ao bom uso de recursos públicos (Maia et al., 2007). Para Riani (1997, p. 69) “Os gastos públicos constituem-se na principal peça de atuação do governo, que estabelece uma série de prioridades no que se refere à prestação de serviços públicos básicos e aos investimentos a serem realizados.”

A Administração Pública vem sofrendo avanços nessa área desde o final do século XX, a Constituição de 1988, instituiu normas para licitações e contratos da Administração Pública e em seu artigo 37, determinou que a administração pública obedeça aos princípios de legalidade, impessoalidade, moralidade, publicidade e eficiência. No inciso XXI do referido artigo, a Carta Magna estabelece a obrigatoriedade de licitar:

ressalvados os casos especificados na legislação, as obras, serviços, compras e alienações serão contratados mediante processo de licitação pública que assegure igualdade de condições a todos os concorrentes, com cláusulas que estabeleçam obrigações de pagamento, mantidas as condições efetivas da proposta, nos termos da lei, o qual somente permitirá as exigências de qualificação técnica e econômica indispensáveis à garantia do cumprimento das obrigações. (BRASIL, 1988).

Com o intuito de regulamentar o artigo 37, inciso XXI da Constituição Federal e estabelecer normas para a realização de licitações e contratos da Administração Pública como também, dar outras providências, editou-se a Lei $n^{\circ} 8.666 / 93$, considerada como sendo "um importante instrumento de consolidação do regime democrático brasileiro" possibilitando a "igualdade de tratamento e a liberdade de ação [...] ao assegurar a todos os interessados, liberdade de participação igualitária em processos destinados a selecionar bens e serviços para a administração pública" (BRASIL, 1993, p.19).

Ao discorrer sobre Compras, a referida Lei em seu artigo $15^{\circ}$, inciso II, diz que, sempre que possível elas devem ser processadas por meio de Sistema de Registro de Preços. A fim de reforçar o SRP, a Lei 10.520/2002 em seu artigo $11^{\circ}$, instituiu a modalidade de licitação denominada Pregão, para aquisição de bens e serviços comuns. Com o intuito de regulamentar o 
Sistema de Registro de Preços, foi instituído o Decreto № 7.892, de 23 de Janeiro de 2013, revogando o Decreto n. ${ }^{\circ} 4.342$, de 23 de agosto de 2002, onde consta a possibilidade de adesão da ata de registro de preço por órgãos não participantes (carona).

No que tange as compras públicas brasileiras, a modalidade de Pregão Eletrônico implementa um mecanismo de leilão reverso baseado no atributo preço, permitindo a disputa por contratos, mediante a submissão de lances decrescentes, por fornecedores, através do próprio site do Portal Compras Governamentais. (MENEZES, SILVA e LINHARES, 2007).

O pregão eletrônico além de simplificar todo o procedimento administrativo, alcança índices consideráveis de economia de recursos em virtude de poder alcançar grande parte do território nacional por meio do uso da Internet. Assim, constata-se uma evolução no que se refere à compra de bens/serviços comuns, que a partir da introdução dessa modalidade vem proporcionando maior eficiência na administração dos recursos públicos. (NUNES, LUCENA e SILVA, 2014).

A ótima gestão dos recursos públicos é um anseio governamental. Sendo a Administração Pública prestadora de serviços públicos e considerando a escassez dos recursos, a eficiência do gasto passa a ser amplamente exigida pela sociedade, que cobra qualidade dos serviços ofertados e, principalmente, nos resultados atingidos a partir dos dispêndios financeiros empregados pelo governo. (FROSSARD, 2012).

A qualidade do gasto público tem sido assunto de destaque na gestão pública brasileira nos últimos anos. Tendo em vista a importância do tema, essa pesquisa objetiva demonstrar que os processos de contratações públicas podem e devem ser mais céleres, econômicas e efetivas em relação aos recursos empregados, possibilitando gastar menos e produzir mais, sem contrariar as legislações e ordenamentos jurídicos.

Segundo Boueri (2007), uma das maneiras para aprimorar o gasto público é começar a mensurar seus resultados, pois, monitorando-os, é possível obter um parâmetro para cobrar a melhoria da qualidade. A qualidade do gasto nas compras públicas representa grande importância para o Estado, uma vez que consomem parte considerável do produto interno bruto brasileiro. Ao longo dos últimos anos, as contratações públicas vêm evoluindo financeiramente. O total gasto com compras públicas do Poder Executivo Federal, no ano de 2014, foi de aproximadamente R\$ 
76,5 bilhões. Um montante consideravelmente impactante na situação socioeconômica brasileira e, portanto uma ferramenta importante de ação governamental.

De acordo com Matias-Pereira (2010), nos países em desenvolvimento, onde se busca alcançar níveis ideais de desenvolvimento, ampliam-se as atribuições econômicas governamentais, que são executadas por meio de sua ação nas receitas e despesas públicas, sendo o gasto público o principal meio de sua atuação.

Nessa perspectiva, os órgãos públicos federais, como é o caso dos Institutos Federais de Educação, tem a obrigação de atender as exigências das políticas públicas implementadas pelo governo federal, visando o cumprimento de programas voltados para as finalidades de cada órgão, a fim de que os objetivos institucionais sejam alcançados. O que nem sempre ocorre no prazo estabelecido pelas políticas públicas, tendo em vista as limitações de cada órgão, seja no campo de pessoal ou mesmo no campo orçamentário e financeiro. (PACHECO, 1999).

Pensando em eficiência, cabe salientar o que diz Pereira Junior e Dotti (2012), “O governo eficiente e eficaz quer, pode e sabe produzir resultados de interesse público. Não garante tais resultados o governo que afirma querer, mas não estrutura adequadamente a governabilidade, nem domina suficientemente a governança” (PEREIRA JÚNIOR; DOTTI, 2012 p. 55). Nesse sentido é importante refletir sobre a eficiência e eficácia das ações governamentais, a fim de contribuir para que as políticas públicas apresentem resultados satisfatórios e cumpram com seu papel dentro da sociedade.

O foco da investigação foi à análise comparativa das contratações realizadas por pregão eletrônico, que de acordo com Pereira Junior e Dotti (2012) esse procedimento administrativo é considerado atualmente como o mais transparente, econômico e célere para a contratação de bens ou aquisição de serviços de natureza comum, pois é a modalidade que representa os maiores avanços, quanto aos resultados obtidos, em relação às outras modalidades, proporcionando economia de $20 \%$ e $30 \%$ do valor estimado para cada contratação, além de propiciar maior competitividade e simplificação de exigências.

O estudo analisa indicadores de economicidade e eficiência temporal nos processos de compras, no exercício de 2014, realizados na modalidade pregão eletrônico, nos Institutos Federais de Educação, Ciências e Tecnologia da Região Centro Oeste: Instituto Federal de Goiás - IFG; Instituto Federal de Brasília - IFB; Instituto Federal Goiano - IF Goiano; Instituto Federal de Mato 
Grosso - IFMT, e, Instituto Federal do Mato Grosso do Sul - IFMS.

\subsection{Formulação do Problema de Pesquisa}

No que cerne o aperfeiçoamento da gestão dos recursos públicos, buscou-se saber quais os níveis de economicidade e eficiência temporal na modalidade pregão eletrônico dos processos de aquisições de bens materiais e serviços dos Institutos Federais de Educação da Região Centro Oeste.

\subsection{Objetivo Geral}

Analisar as despesas nos processos de compras, realizados no âmbito do Instituto Federal de Educação, Ciências e Tecnologia de Goiás, no exercício de 2014, nas modalidades: Tomadas de Preços, Concorrência, Pregão Presencial e Eletrônico, Dispensa e Inexigibilidade de Licitação.

\subsection{Objetivos Específicos}

Para alcançar este objetivo, foram traçados como objetivos específicos:

- Avaliar as contratações dos Órgãos do Poder Executivo Federal no período de 2010 a 2014;

- Analisar o uso do Pregão Eletrônico no IFG, no exercício de 2014, no tocante aos critérios de economicidade e eficiência temporal;

- Analisar comparativamente as compras nas modalidades: Tomadas de Preços, Concorrência, Pregão Presencial e Eletrônico, Dispensa e Inexigibilidade de Licitação nos Institutos Federais de Educação da Região Centro Oeste. 


\section{REFERENCIAL TEÓRICO}

\subsection{Princípios Norteadores da Administração Pública}

A Administração Pública é a junção de todo o aparelho do Estado, uma estrutura formada com o intuito de realizar serviços públicos, visando a satisfação das demandas populacionais, ou seja, atendendo o bem comum. E, para isso, a Administração pública deve atuar como sendo a ligação direta entre o governo e a sociedade. (MATIAS-PEREIRA, 2010).

Os princípios que regem a Administração Pública são consolidados em conceitos centrais norteadores que são alicerces jurídicos para o perfeito exercício das funções públicas. A CF de 1998 em seu art. 37 define que: “A Administração Pública direta e indireta de qualquer dos Poderes da União, dos Estados, do Distrito Federal e dos Municípios obedecerá aos princípios da legalidade, impessoalidade, moralidade, publicidade e eficiência. (BRASIL, 1998)”.

Os Princípios da Administração Pública subdividem-se em explícitos e implícitos, os explícitos são aqueles que estão previstos na Carta Magna, em seu artigo 37, anteriormente citados, a começar pelo:

Princípio da Legalidade: que nasceu com o Estado de Direito e é o princípio primordial da Administração Pública, ele define que o administrador público, em toda a sua atividade profissional está sujeito a Lei, não podendo desviar-se nem mesmo afastar-se dela, sob modo de sofrer penalidade civil e criminal. Fazendo com que a Administração direta e indireta atue de forma lícita, praticando apenas o que a Lei autoriza. (MEIRELLES, 1999).

Esse princípio encontra fundamentação no inciso II do artigo $5^{\circ}$ da Constituição que dispõe: "ninguém será obrigado a fazer ou deixar de fazer alguma coisa senão em virtude da lei” o que corrobora com o artigo $4^{\circ}$ da Declaração de Direitos do Homem e do Cidadão, de 1789:

a liberdade consiste em fazer tudo àquilo que não prejudica a outrem; assim, o exercício dos direitos naturais de cada homem não tem outros limites que os que asseguram aos membros da sociedade o gozo desses mesmos direitos. Esses limites somente podem ser estabelecidos em lei. (DECLARAÇÃO, 1789). 
Sendo assim, aos administradores públicos cabe fazer somente aquilo que a Lei estabelece e assim, não havendo legislação não há atuação administrativa válida. Bandeira de Mello (2008, p.100) explana que o Princípio da Legalidade é:

[...] princípio capital para configuração do regime jurídico-administrativo. Justifica-se, pois, que seja tratado - como o será - com alguma extensão e detença. [...], o da legalidade é específico do Estado de Direito, é justamente aquele que o qualifica e que lhe dá a identidade própria. Por isso mesmo é o princípio basilar do regime jurídico-administrativo, já que o Direito Administrativo (pelo menos aquilo que como tal se concebe) nasce com o Estado de Direito: é uma consequiência dele. É o fruto da submissão do estado à lei. É em suma: a consagração da idéia de que a Administração Pública só pode ser exercida na conformidade da lei e que, de conseguinte, a atividade administrativa é atividade sublegal, infralegal, consistente na expedição de comandos complementares à lei. (grifo do autor).

É importante salientar que o princípio da legalidade concebe uma garantia para os administrados, pois, qualquer ação da Administração Pública somente será legítima se respaldada em lei. Impondo assim, um limite para a atuação do Estado, visando à proteção do administrado em relação ao abuso de poder. (IURCONVITE, 2006).

Princípio da Impessoalidade: A Administração Pública deve ser impessoal e todo e qualquer ato administrativo deverá sempre promover o interesse coletivo e direito, não podendo, portanto obter vantagem própria nem favorecer terceiros e sim favorecer o bem comum.

Assim, a autora Maria Silvia Zanella di Pietro, afirma sobre o princípio da impessoalidade em sua magnitude na Administração Pública, observemos:

Este princípio, que aparece, pela primeira vez, com essa denominação, no art. 37 da Constituição de 1988, está dando margem a diferentes interpretações, pois, ao contrário dos demais, não tem sido objeto de cogitação pelos doutrinadores brasileiros. Exigir impessoalidade da Administração tanto pode significar que esse atributo deve ser observado em relação aos administrados como à própria Administração. No primeiro sentido, o princípio estaria relacionado com a finalidade pública que deve nortear toda a atividade administrativa. Significa que a Administração não pode atuar com vistas a prejudicar ou beneficiar pessoas determinadas, uma vez que é sempre o interesse público que tem que nortear o seu comportamento. (DI PIETRO, 2014, p.68).

O Administrador deve agir sempre em nome da Administração Pública, ou seja, o gestor não pode usar do seu poder discricionário para promover-se ou à sua gestão, nem mesmo privilegiar terceiros, devendo sim, agir de forma a promover a igualdade de direitos e ser impessoal. 
O Princípio da Moralidade deve ser seguido pelo Administrador Público em todas as suas ações, a honestidade tem que ser peça fundamental no exercício da sua função e também em seu dia-a-dia. Esse princípio exige do Administrador Público uma conduta pautada na legalidade e legitimidade, a fim de produzir uma Administração transparente e participativa.

Di Pietro (2014) afirma que o Princípio da Moralidade exige da Administração conduta não apenas lícita, como também de acordo com a moral, os bons costumes, as regras de boa administração, os princípios de justiça e equidade, e a ideia comum de honestidade.

Bandeira de Mello (2006) assevera que, a violação do Princípio da Moralidade por parte da Administração Pública assemelha-se ao agente público ferindo o direito em si, e cometendo então uma ilegalidade, que deve ser invalidada de modo a atender a moral e os bons costumes.

O Princípio da Eficiência compreende a produção dos resultados almejados pela Administração Pública, em tempo hábil e preciso, com o menor desperdício possível, visando atender ao interesse público. Di Pietro (2014) esclarece que esse princípio apresenta-se em dois aspectos:

pode ser considerado em relação ao modo de atuação do agente público, do qual se espera o melhor desempenho possível de suas atribuições, para lograr os melhores resultados; e em relação ao modo de organizar, estruturar, disciplinar a Administração Pública, também com o mesmo objetivo de alcançar os melhores resultados na prestação do serviço público. (grifo do autor). (DI PIETRO, 2014, p.84).

Meirelles (1999) diz que o Princípio da Eficiência exige do agente público o desempenho de suas atividades não só dentro da legalidade como também exigindo resultados positivos da administração pública, com a finalidade de dar o atendimento satisfatório para as demandas dos administrados.

O Princípio da Publicidade é o que rege a transparência, não permitindo que assuntos de interesse público sejam omitidos dos administrados, exceto assuntos de sigilo no caso de segurança nacional e particulares, resguardados pela Constituição Federal. É obrigatória a divulgação de todos os atos, contratos e instrumentos celebrados pela Administração Pública direta e indireta, para fins de controle e salvaguarda do patrimônio público. Meirelles esclarece que o Princípio da Publicidade é: 
A divulgação oficial do ato para o conhecimento público e início dos seus efeitos externos. Daí porque as leis, atos e contratos administrativos que produzem consequências jurídicas fora dos órgãos que os emitem, exige publicidade para adquirirem validade universal, isto é, perante partes e terceiros. (MEIRELLES, 1997, p.83).

Portanto, o Princípio da Publicidade atua como aporte ao acompanhamento da gestão pública, aumentando o monitoramento, a transparência e promovendo a atuação da sociedade participativa que, ao acompanhar as ações da Administração Pública proporciona melhoria na condução das atividades administrativas.

Alguns Princípios da Administração Pública estão subentendidos no texto da Constituição Federal, e, portanto, são considerados implícitos. O Princípio da Finalidade é um deles e que de acordo com Meirelles (2008, p.93), “esse princípio nada mais é que o da impessoalidade, uma vez que impõe ao administrador público que só pratique o ato para o seu fím legal. Daí ser ele decorrente do princípio da legalidade."

Bandeira de Mello (2006) confronta essa afirmativa quando diz que: o princípio da finalidade está inerente ao princípio da legalidade, estando nele contido, "pois corresponde à aplicação da lei tal qual é; ou seja, na conformidade de sua razão de ser, do objetivo em vista do qual foi editada.” (MELLO, 2006, p.95).

O Princípio da Igualdade ou Isonomia é garantido no art. $5^{\circ}$ da Constituição Federal, onde afirma que "Todos são iguais perante a lei, sem distinção de qualquer natureza, garantindo-se aos brasileiros e aos estrangeiros residentes no País a inviolabilidade do direito à vida, à igualdade, à segurança e à propriedade, (...)” devendo ser respeitado, e todas as demais normas devem obedecêlo. (BRASIL, 1998, p.2).

Gasparini (2008) deixa claro que, o objetivo do princípio da igualdade é evitar privilégios, e quando estabelecidos servir de fundamento para sua extinção. Essa igualdade não se trata de uma igualdade financeira, mas jurídico-formal.

O Princípio da Razoabilidade é proposto para que a Administração Pública atue de forma razoável e dentro dos padrões da legalidade, ou seja, impõe limites à discricionariedade administrativa. Bandeira de Mello explana que:

Enuncia-se com este princípio que a administração, ao atuar no exercício de discrição, terá de obedecer a critérios aceitáveis do ponto de vista racional, em sintonia com o senso 
normal de pessoas equilibradas e respeitosas das finalidades que presidam a outorga da competência exercida. (MELLO, 2006, p.97).

Corroborando com o exposto, Gasparini (2008, p.25) afirma "Nada que esteja fora do razoável, do sensato, do normal, é permitido ao agente público, mesmo quando atua no exercício de competência discricionária."

O Princípio da Segurança Jurídica pode ser considerado o mais importante na estrutura do Estado Democrático do Direito, pois corresponde justamente aos anseios do cidadão, como a estabilidade e a certeza da vida social e de tudo aquilo que o cerca. Destacam-se os institutos da usucapião, da irretroatividade da lei, da prescrição, da decadência, da preclusão e do direito adquirido. (ADDISON, 2009).

O Princípio da Ampla defesa e contraditório garante que a Administração Pública antes de agir ou mesmo julgar quem quer que seja, dê-lhe o direto da ampla defesa e contraditório, que também pode ser usado no caso da recorrência de julgado, assim quando lhe couber. Esse princípio tem garantia na Constituição Federal em seu art. $5^{\circ}$, incisos LIV e LV que diz:

LIV - ninguém será privado da liberdade ou de seus bens sem o devido processo legal;

LV - aos litigantes, em processo judicial ou administrativo, e aos acusados em geral são assegurados o contraditório e ampla defesa, com os meios e recursos a ela inerentes; (BRASIL, 1988).

O princípio da supremacia do interesse público está no baseamento de praticamente todas as funções do Estado e de todos os ramos do direito público Está contida nos quatro tipos de funções administrativas serviço público, fomento, polícia administrativa e intervenção. Esse princípio é inerente à própria definição de serviço público; este é público porque é de titularidade do Estado, e é de titularidade do Estado porque atende a necessidades coletivas. (DI PIETRO, 2014).

Toda e qualquer ação da Administração Pública, deve ser pautada na Lei e ter como finalidade atender ao interesse público, se a Legalidade e a Supremacia do interesse público não forem respeitadas, essas atuações devem ser revistas.

A correta aplicação dos recursos públicos, e, a maior eficiência nos gastos tem como finalidade não só de evitar desvios, como também de garantir a economicidade quanto à aplicação 
desses recursos. A Constituição Federal de 1988, em seu artigo 70, assevera o Princípio da Economicidade quando assinala que:

a fiscalização contábil, financeira, orçamentária, operacional e patrimonial da União e das entidades da administração direita e indireta, quando a legalidade, legitimidade, economicidade, aplicação das subvenções e renúncias de receitas, será exercida pelo Congresso Nacional, mediante controle externo, e pelo sistema de controle interno de cada Poder. (BRASIL, 1998).

Os Princípios norteadores da Administração Pública, sejam eles explícitos ou implícitos, propagam valores sociais, jurídicos e éticos que auxiliam os agentes públicos no exercício de suas ações. Esses Princípios regulam a forma de agir da Administração Pública, seja ela direta ou indireta, no Poder Federal, Estadual, do Distrito Federal e dos Municípios.

\subsection{Orçamento Público}

Nas últimas décadas, o processo orçamentário brasileiro passou por transformações, que tinham como intuito maximizar a eficiência dos fatores de produção e da qualidade dos serviços prestados pelo governo, principalmente com o incentivo à inovação e por meio da revisão de paradigmas associados aos modelos, patrimonial e burocrático de Administração Pública. (BRESSER-PEREIRA, 1996).

O Orçamento Público é a ferramenta utilizada pelos Governos para organizar suas finanças, anualmente ele é materializado numa lei específica que "estima a receita, fixa a despesa" federal, de cada exercício financeiro. Esse controle garante que as despesas só poderão ser realizadas se estiver prevista ou forem incorporadas ao orçamento.

Sanches (2007) expõe que o orçamento desde os primórdios tem sido entendido como instrumento político, isso porque estabelece regras para a cobrança de tributos, fixa limites para as despesas públicas, responsabiliza e articula parte expressiva do sistema de checks and balances constituído pela sociedade para controlar o exercício do poder que defere ao Estado.

A Constituição Federal promulgada em 1988 proporcionou inovações no campo da gestão das instituições do Estado. Pela primeira vez, a lei maior dá inequívoco destaque ao planejamento propendendo o desenvolvimento nacional equilibrado. Ao lado dos planos de desenvolvimento, 
nacionais, regionais e setoriais, de caráter indicativo para o setor privado, a Carta Magna instituiu o funcionamento da administração pública sob o marco sistêmico de três leis hierarquizadas e integradas: o plano plurianual, as diretrizes orçamentárias e o orçamento anual. (GIACOMONI, 2004).

Carvalho (2014) confirma a necessidade que o Estado tem em Planejar. Esse planejamento, conforme a legislação atual (Constituição Federal de 1988, Lei de Responsabilidade Fiscal de 2000 e Lei $\left.n^{\circ} 4.320 / 1964\right)$, será substancializado por meio dos instrumentos de planejamento da Administração Pública: Plano Plurianual, Lei de diretrizes Orçamentárias, Lei Orçamentária Anual e Planos e Programas Regionais e Setoriais.

A Lei Federal No 4.320, instituída no ano de 1964, estatui Normas Gerais de Direito Financeiro para elaboração e controle dos orçamentos e balanços da União, dos Estados, dos Municípios e do Distrito Federal. "Art. $2^{\circ}$ A Lei do Orçamento conterá a discriminação da receita e despesa de forma a evidenciar a política econômica financeira e o programa de trabalho do Governo, obedecidos os princípios de unidade, universalidade e anualidade.” (BRASIL, 1964).

A mesma lei introduz o significado e a competência do Controle no âmbito interno, logo em seguida o Decreto Lei n ${ }^{\circ}$ 200/67 no art. 60, estabelece o "controle" como um dos princípios fundamentais que as atividades da administração federal devem obedecer, determinando a criação do Controle Interno na estrutura do Poder Executivo. Continuamente com a Constituição da República Federativa do Brasil de 1988, assinalou-se nos termos do artigo 70, a competência do Controle Interno vinculada à administração pública de fiscalizar a gestão pública por meio das atividades de controle operacional, patrimonial, contábil, financeiro e orçamentário.

Em suma, Carvalho (2014) elucida a Lei Orçamentária como sendo: uma lei formal apesar de ser uma lei, não obriga o Poder Público a realizar uma despesa, mesmo que essa despesa seja autorizada pelo Legislativo, o Governo pode deixar de fazê-la. Entretanto, existem gastos que são obrigatórios, como por exemplo, as despesas mínimas com saúde e educação; é uma lei temporária - tem vigência limitada (um ano); é uma lei ordinária e é uma lei especial que possui processo legislativo diferente das leis comuns, uma vez que trata de matéria específica. 


\subsubsection{Princípios Básicos do Orçamento Público}

Os princípios orçamentários propendem estabelecer regras básicas, a fim de atribuir racionalidade, eficiência e transparência aos processos de elaboração, execução e controle do orçamento público, são aplicados aos Três Poderes e entes da federação, sendo instituídos e disciplinados tanto por normas constitucionais e infraconstitucionais quanto pela doutrina. (BRASIL, 2015e). A Lei Federal No 4.320 de 1964, em seu artigo $2^{\circ}$ estabelece os princípios de unidade, universalidade e anualidade.

O princípio da unidade ou totalidade, institui que todas as despesas e receitas dos órgãos e entidades da Administração Pública que fazem parte do orçamento fiscal e da seguridade social devem fazer parte de apenas um documento, que é a Lei Orçamentária. Esse princípio só passou a existir de fato após a Constituição Federal de 1988, que extinguiu todo e qualquer orçamento paralelo a União, Estados/DF e Municípios. O artigo $5^{\circ}$ da CF/1988 determina que a Lei Orçamentária Anual - LOA, será constituída dos orçamentos fiscal, de investimento e da seguridade social. Configurando então o princípio da totalidade. (CARVALHO, 2014).

Carvalho (2014) versa que, de acordo com o princípio da universalidade, o orçamento deve ser (uno) contendo nele todas as receitas previstas para serem arrecadadas no ano seguinte e despesas fixadas para o exercício subsequente, isso porque o orçamento é elaborado em um ano para ser executado no outro. Essa universalidade possibilita maior controle pelo Legislativo e órgãos fiscalizadores.

O princípio da anualidade estabelece que o orçamento deva ter vigência de um exercício financeiro, isto é, nem sempre coincide com o ano civil. Entretanto, no Brasil a legislação por meio da Lei 4.320/64 em seu artigo 34, institui que o “o exercício financeiro coincidirá com o ano civil”. Nesse sentido, o Legislativo autoriza anualmente, a cada exercício financeiro, a realização das despesas públicas, controlando a arrecadação e execução dos dispêndios. De acordo com Silva, "obrigar o Poder Executivo a solicitar periodicamente ao Parlamento autorização para a cobrança de tributos e para a aplicação do respectivo produto." (SILVA, 1962, p. 34).

O princípio da exclusividade dispõe que a Lei Orçamentária Anual não poderá conter “dispositivos estranhos à fixação das despesas e previsão de receitas, ressalvadas a autorização para 
a abertura de créditos suplementares e contratação de operação de crédito, ainda que por antecipação da receita.” (CARVALHO, 2014, p.55).

A Lei $\mathrm{n}^{\circ} 4.320 / 64$ em seu artigo $6^{\circ}$ estabelece que "Todas as receitas e despesas constarão na Lei do Orçamento pelos seus totais, vedadas quaisquer deduções”. Assim sendo, todas as receitas e despesas devem constar na peça orçamentária pelos seus valores totais, isto é, sem deduções e ou compensações.

O princípio do equilíbrio orçamentário evidencia que, os valores autorizados para serem realizados nas despesas do exercício deve estar em concordância com os valores das receitas previstas para serem arrecadadas, ou seja, o total das despesas deve ser idêntico ao das receitas, para que no final do exercício financeiro essa igualdade seja evidenciada nas demonstrações contábeis. Se isso não ocorre, resulta em resultados negativos, o que compromete o cumprimento das metas fiscais. Carvalho (2014,) assegura que:

“O princípio do equilíbrio deve ser alcançado mesmo quando durante o exercício financeiro, a arrecadação não atingir o montante previsto na Lei Orçamentária Anual. Nesta situação, basta que o gestor público limite a emissão de empenho, ou seja, deve-se realizar despesas conforme o fluxo de caixa do ente." (CARVALHO, 2014 p. 62).

O princípio da não afetação ou não vinculação das receitas é previsto constitucionalmente no artigo 167, inciso IV, onde fica vedado a vinculação de receita de impostos a uma determinada despesa, exceto as ressalvas estabelecidas na própria Constituição. Entretanto, em 2003, a Emenda Constitucional $n^{\circ} 42$ ampliou a vinculação da receita de impostos, taxas, contribuições de melhorias e contribuições sociais e econômicas a determinados investimentos.

O princípio da clareza é de extrema importância, pois torna o orçamento um instrumento eficaz e eficiente de políticas públicas. De acordo com esse princípio a LOA deve ser estruturada de forma clara e objetiva, utilizando de categorias e elementos que facilitem a compreensão de qualquer indivíduo. $\mathrm{O}$ atendimento a esse princípio, possibilita um maior controle social, facilitando o exercício da cidadania. (CARVALHO, 2014).

A publicidade é um dos princípios que regem a Administração Pública, ela garante que todas as informações relacionadas aos atos e fatos públicos sejam disponibilizadas a qualquer cidadão que tenha interesse em acessá-las. Silva (1973, p 155) afirma que "a publicidade é um 
princípio básico da atividade do poder público no regime democrático, aplicando-se também ao orçamento, que é a peça fundamental da atividade governamental”.

O princípio da especificação ou especialização (discriminação da despesa) é clássico e de caráter formal. Ele estabelece que as receitas e despesas públicas devem estar no orçamento com um nível razoável de detalhamento ou especificação, com finalidade de apoiar a fiscalização. Essa discriminação deve ocorrer de forma que um cidadão leigo, ao observar a estrutura orçamentária, conheça a origem dos recursos e sua aplicação. (CARVALHO, 2014).

De acordo com Silva (1973, p.153), “o princípio da legalidade em matéria orçamentária tem o mesmo fundamento do princípio da legalidade geral, segundo o qual a administração se subordina aos ditames da lei."

O princípio da prévia autorização ou legalidade é um dos mais importantes, pois visa combater as arbitrariedades provenientes do Poder Público, orientando a estruturação do sistema orçamentário. Em função desse princípio, o planejamento e orçamento são realizados através dos instrumentos orçamentários (Plano Plurianual, Lei de Diretrizes Orçamentárias, Lei Orçamentária Anual), que são preparados e encaminhados para o Legislativo, para ser discutido e aprovado. (CARVALHO, 2014).

O princípio da programação é definido por Sanches (2004) como sendo um princípio orçamentário, de natureza complementar, que diz que o orçamento público deverá ser estruturado sob a forma de programação, ou seja, ele deve demonstrar o programa de trabalho de cada entidade pública, com detalhamentos próprios, que expressem como, onde e com que amplidão o poder público irá atuar no exercício a que se refere à Lei Orçamentária.

O princípio da continuidade dos serviços públicos alberga a conceito da continuidade dos serviços essenciais a sociedade, isto é, uma vez que os serviços públicos são indispensáveis e fundamentais ao exercício da cidadania, não devem ser interrompidos. Di Pietro (2002, p.74) afirma que: "Por esse princípio entende-se que o serviço público, sendo a forma pela qual o Estado desempenha funções essenciais ou necessárias à coletividade, não pode parar”.

O princípio da impessoalidade é explicitado no artigo 100 da Constituição Federal onde institui a obrigatoriedade "do pagamento dos débitos decorrentes de decisão judicial transitada em julgado pelo sistema de precatórios, na estrita ordem cronológica de sua apresentação, vedando-se a designação de pessoas ou situações específicas. (CARVALHO, 2014, p.76)”. 
A Publicidade e clareza são as ferramentas fundamentais do Princípio da transparência, pois mesmo que todas as informações forem amplamente divulgadas de nada adianta de não forem claras e compreensíveis ao grande público. A transparência, portanto, depende de importantes fatores como relevância, confiabilidade e oportunidade. (PLATT NETO, 2005).

Carvalho (2014) discorre que o princípio da transparência determina que o governo deva divulgar o orçamento público, de modo que, sejam disponibilizados todos os relatórios sobre arrecadação de receita e execução de despesa, bem como, execução orçamentária e gestão fiscal, a qualquer cidadão que queira ter acesso a essas informações.

\subsubsection{Finanças Públicas}

O Estado existe essencialmente para proporcionar o bem-comum. Três vertentes são propostas pelos estudiosos que se debruçam sobre essa análise de finalidade do Estado, quais são: bem-estar, segurança e justiça. Essas vertentes são intrínsecas, interligadas e com um único fim: proporcionar o bem-comum. O Estado também tem o papel de agente fiscal, devendo agir de forma a controlar suas despesas, para isso é necessária a devida aplicação do Princípio do Equilíbrio, de modo que, esse equilíbrio faça atender à renda e ao gasto público e não somente às finanças públicas. (MATIAS-PEREIRA, 2010).

As Finanças Públicas é em sua totalidade o conjunto de métodos, princípios e conjunto de procedimentos que o Estado utiliza para desempenhar as suas funções econômicas que de acordo com Musgrave (1994) são as funções:

- $\quad$ Alocativa - Os bens e serviços públicos não podem ser fornecidos de acordo com as demandas da sociedade, sendo assim, o governo divide os recursos para utilização no setor público e privado, oferecendo bens públicos.

- Distributiva - o Poder Público assume o papel de um redistribuidor de renda, transferindo a renda de parcela dos que tem mais, para aqueles que têm menos, e para isso, o Governo utiliza-se de transferências fiscais, tributação progressiva da renda, subsídios a famílias de baixa renda etc.

- Estabilizadora - O governo utiliza-se da função estabilizadora para estimular ou conter a demanda agregada, por meio da sustentação dos níveis de emprego, 
estabilização dos preços, equilíbrio nas despesas e manutenção de uma boa taxa de crescimento econômico.

\title{
2.2.2.1. Receitas Públicas
}

O Tesouro Nacional em seu manual de procedimentos - Receitas Públicas - define a receita como sendo:

\begin{abstract}
a expressão monetária resultante do poder de tributar e/ou do agregado de bens e/ou serviços da entidade, validada pelo mercado em um determinado período de tempo e que provoca um acréscimo concomitante no ativo ou uma redução do passivo, com um acréscimo correspondente no patrimônio líquido, abstraindo-se do esforço de produzir tal receita representado pela redução (despesa) do ativo ou acréscimo do passivo e correspondente redução do patrimônio líquido. (BRASIL, 2005, p.12).
\end{abstract}

O Governo necessita de obtenção de recursos financeiros para que consiga cumprir com suas finalidades e é nesse sentido que ocorre a atividade financeira do Estado, com o intuito de alavancar recursos suficientes para realização das despesas públicas no atendimento das demandas da sociedade. No Brasil a principal fonte de receitas são os tributos (impostos, taxas, contribuição de melhorias, contribuições sociais e econômicas entre outros.) que são cobrados dos cidadãos de forma contínua e permanente com o objetivo de realizar gastos para atender as demandas da população e desenvolvimento do Estado. (CARVALHO, 2014).

\subsubsection{Despesas Públicas}

A despesa pública é conceituada por Baleeiro (1996, p.65) como sendo "o conjunto dos dispêndios do Estado ou de outra pessoa de direito público, para o funcionamento dos serviços públicos."

Já Gomes (2000, p.57), a define como "o exato cumprimento dos fins do Estado - atender às necessidades públicas, que são infinitas, embora seja dispensáveis a racionalidade, porque os recursos são finitos." Corroborando com os autores anteriores Carvalho diz que a despesa pública é: 
O conjunto dos dispêndios realizados pelos entes públicos para custear os serviços públicos prestados à sociedade ou para a realização de investimentos. Em outras palavras, as despesas públicas são aplicações em dinheiro de recursos arrecadados pelo Estado com o objetivo de prover os serviços de ordem pública ou atender o próprio desenvolvimento econômico do Estado. (Carvalho, 2014, p. 380).

Para a contabilidade pública quaisquer que seja o desembolso de recurso financeiro é considerada despesa pública, mesmo que seja uma mera restituição de recursos de terceiros. Entretanto para o perfeito controle da execução orçamentária, é necessário compreender se esse dispêndio gerou algum comprometimento dos recursos a serem aplicados em outras atividades. Podemos então considerar como despesa pública o desembolso de recurso financeiro, como despesa patrimonial o fato administrativo que decresce o valor do patrimônio líquido e como despesa orçamentária a utilização do crédito orçamentário no momento da emissão do empenho de despesa. (CARVALHO, 2014).

\subsection{Compras Públicas Federais}

A Lei 8.666 de 21 de junho de 1993, artigo 6º inciso III, considera como compra "toda aquisição remunerada de bens para fornecimento de uma só vez ou parceladamente." (BRASIL, 1993). A Constituição Federal de 1988, em seu artigo 37, inciso XXI, optou por um regime de contratação com base em competição seletiva aberta, assegurando igualdade de condições a todos os concorrentes, denominada licitação, ressalvada as situações de exceção previstas em lei.

A Lei 8.666 de 1993 e suas alterações estabelecem em seu artigo 1': "Normas gerais sobre licitações e contratos pertinentes a obras, serviços, inclusive de publicidade, compras, alienações e locações no âmbito dos Poderes da União, dos Estados, do Distrito Federal e dos Municípios.” E em seu artigo $2^{\circ}$ corrobora com a Carta Magna ao estabelecer que todos esses contratos acima mencionados quando realizados com terceiros, "serão necessariamente precedidas de licitação, ressalvadas as hipóteses previstas em lei." (BRASIL, 1993).

A mesma Lei, em seu artigo $14^{\circ}$ institui que nenhuma compra será realizada sem a caracterização adequada de seu objeto e indicação dos recursos orçamentários para seu pagamento, sob penalidade de nulidade do ato e responsabilização de quem o fizer. $\mathrm{O}$ artigo $15^{\circ} \mathrm{em}$ seus incisos

I, II, III, IV e V orientam que todas as compras públicas sempre que possível deverão atender ao 
princípio da padronização; ser processadas através de Sistema de Registro de Preços; submeter-se às condições de aquisição e pagamento semelhantes às do setor privado; ser subdivididas em quantas parcelas quanto forem necessárias, visando a economicidade; tomar como base os preços praticados no âmbito dos órgãos e entidades da Administração Pública. (BRASIL, 1993).

A efetividade e a eficiência da função compras se tornam primordiais para o sucesso das organizações inseridas em mercados altamente competitivos. As compras públicas devem obedecer aos requisitos de eficiência, eficácia e efetividade, dado que os recursos advêm dos contribuintes. O Pregão representa um aprimoramento no regime de licitações para a Administração Pública, pois possibilita o aumento da competitividade e a ampliação das oportunidades de participação nos processos de licitação, contribuindo para a redução das despesas, sobretudo as de custeio da máquina administrativa, indo ao encontro das metas de ajuste fiscal. (MENEZES, SILVA e LINHARES, 2007).

O setor de compras e aquisições tem uma das funções de maior importância em qualquer instituição, sejam elas públicas ou privadas, a boa administração desse setor possibilita que os objetivos das organizações sejam alcançados com bom êxito. Uma compra bem realizada proporciona o maior custo benefício, ou seja, comprar mais e melhor com menos, isso em uma instituição privada traz satisfação aos acionistas e em uma instituição pública, a economia e boa gerência do dinheiro público, proporcionando melhores serviços mais eficientes e eficazes à sociedade. (NUNES, LUCENA e SILVA, 2007).

Nunes, Lucena e Silva (2007) abordam que existem diferenças salutares entre o sistema de compras no setor público e o das empresas privadas. Enquanto que as empresas privadas têm liberdade para negociar e poder de decidir pelas suas aquisições pensando apenas na minimização dos seus custos e maximização dos lucros, o setor público tem obrigação de pensar no benefício da coletividade e só podem ir até onde a lei permite, em respeito ao princípio da Legalidade. Para isso é necessário uma gestão de compras e aquisições eficiente que atue de forma transparente para o bom atendimento das demandas propostas pela sociedade.

A organização produtiva na atualidade vê a compra como sendo uma atividade estratégica fundamental. Na visão de Baily et al. (2000), as instituições que utilizam dessa atividade na abordagem competitiva para a administração de materiais, estão expondo ideias de integração baseadas na função estratégica e integrada das compras. Com isso, as organizações de sucesso 
estimulam o interesse de outras instituições para replicar esse sucesso ampliando a relevância da função compras.

A função compras assume, nos dias atuais, um caráter estratégico, sendo elemento decisivo para que organizações inseridas em ambientes complexos, dinâmicos e altamente competitivos, obtenham vantagens competitivas nos mercados em que atuam. A Teoria dos Leilões fornece um modelo explícito de formação de preços, cuja principal atributo é desobrigar o vendedor da tarefa de fixação do preço do bem, deixando que este seja estabelecido pelo próprio mercado. Com regras simples e bem determinadas, os leilões geram maior flexibilidade à tarefa de cotação de preços, na medida em que, abre espaço para negociação entre as partes. (MENEZES, SILVA e LINHARES, 2007).

Nas economias contemporâneas a prática de leilões passou a representar um papel cada vez mais importante como instrumento de aquisição de bens. $\mathrm{O}$ setor público, por exemplo, os utiliza fortemente, quer na venda dos seus títulos quer na aquisição de bens e serviços. As licitações públicas são em geral classificadas como leilões selados de primeiro maior lance. Evidentemente, num processo de licitação desse tipo, o vendedor com o menor preço ganha a concorrência. (MENEZES, 1994).

A questão-chave relacionada com a formatação das licitações é, na verdade, a mesma da teoria dos leilões - isto é, a obtenção de efeitos de assimetria informacional no processo de compra. O governo (ou o leiloeiro) desconhece os custos reais de produção (ou o montante real que a outra parte estaria disposta a pagar) dos participantes da licitação (ou do leilão). Se o governo conhecesse essa informação, não haveria precisão alguma de organizar um processo formal de compra. Poderia simplesmente adquirir o bem da empresa, oferecendo o menor preço. Esses problemas são essencialmente harmônicos, e é por essa razão que a teoria dos leilões está sendo usada na literatura acadêmica e pelos governos empenhados em fazer licitações. (BLUMENSCHEIN, 2014)

\subsubsection{Sistema de compras governamentais}

Faria et al. (2010) esclarece que, em entidades públicas, a meta da administração é a clareza e lisura das relações e o ótimo utilização do dinheiro público para o atendimento satisfatório das demandas da sociedade. A Poder Público, em todas as suas esferas tem o dever de respeitar e 
cumprir os princípios estabelecidos para a Administração Pública para a preservação de valores que avalizem a eficiência e a eficácia na gerência de bens públicos dos cidadãos, e para atingir esse objetivo é necessário fazer o uso da legalidade, obedecendo aos formalismos impostos para as aquisições de bens e contratações de serviços.

As aquisições de materiais e prestações de serviços contratadas pelo Governo Federal são regulamentadas pela Lei $\mathrm{n}^{\mathbf{0}}$ 8.666, de 21 de junho de 1993, com as alterações introduzidas pelas Leis $\mathrm{n}^{\circ}$ 9.648, de 27 de maio de 1998, e 9.854, de 28 de outubro de 1999.

A Lei 8.666/93 sofre um processo de revisão, posto que, o Brasil tem a necessidade de uma lei de licitações efetiva, que atenda as demandas da sociedade, sendo ao mesmo tempo uma ferramenta mais eficaz para todos os atores participantes desse procedimento. (BRAGA et al, 2006).

Com o intuito de atendimento à precisão de revisão dos procedimentos licitatórios instituídos pela Lei $n^{\circ} 8.666 / 93$, em busca de agilidade e eficiência, foi instituída a modalidade pregão, criada pela Medida Provisória n ${ }^{\circ}$ 2.026, de 4 de março de 2000, que aumentou a eficiência processual, embora seja aplicação se dê apenas à aquisição de bens e serviços comuns, que são aqueles cujos padrões de desempenho e qualidade possam ser claramente definidos pelo edital, por meio de especificações usuais do mercado, contemplando itens rotineiramente oferecidos pelo mercado. (VILHENA e HIRLE, 2012).

No tocante a modalidades de licitação, além do convite, onde o interessados do ramo pertinente ao seu objeto, cadastrados ou não, serão escolhidos e convidados em número mínimo de 3 pela Licitante, a qual afixará, em local apropriado, cópia do instrumento convocatório e o estenderá aos demais cadastrados na correspondente especialidade que manifestarem seu interesse com antecedência de até 24 horas da apresentação das propostas, existe o concurso, que ocorrerá entre quaisquer interessados para escolha de trabalho técnico, científico ou artístico, onde haverá a instituição de prêmios ou remuneração aos vencedores, conforme edital publicado na imprensa oficial com antecedência mínima de 45 dias. (BRASIL, 1993). E, o leilão, que consiste na destinação de direitos de propriedade, com base em licitação por preço entre compradores (ou vendedores) à compra (ou à venda) de um bem ou serviço. No caso das compras públicas, ocorre o contrário: a licitação é realizada entre vendedores para a obtenção do direito de vender. (BLUMENSCHEIN, 2014). 
São previstas também as modalidades de concorrência, na qual podem participar todos os interessados que comprovem possuir os requisitos mínimos de qualificação exigidos no edital; tomada de preços, aberta somente aos cadastrados, observada a necessária qualificação; convite, em que participam convidados, em número mínimo de três, cadastrados ou não, analisada a necessária qualificação; e pregão, em que a disputa pelo é realizada por meio de propostas e lances em sessão pública. Ademais, estão previstos dois casos excepcionais: dispensa de licitação, em que são determinadas situações em que os procedimentos anteriores são dispensados, e inexigibilidade de licitação, para as situações que apresentam inviabilidade de competição, como é o caso de presença de fornecedor único de bem ou serviço (MOREIRA E MORAIS, 2003, grifo nosso).

O Pregão na forma eletrônica, para aquisição de bens e serviços comuns, foi regulamentado pelo Decreto $n^{\circ} 5.450$ de 31 de Maio de 2005, em seu artigo $2^{\circ}$ que estabelece:

Art. $2^{\circ} \mathrm{O}$ pregão, na forma eletrônica, como modalidade de licitação do tipo menor preço, realizar-se-á quando a disputa pelo fornecimento de bens ou serviços comuns for feita à distância em sessão pública, por meio do sistema que promova a comunicação via internet. (BRASIL, 2005, p.1).

O Sistema Integrado de Administração de Serviços Gerais - SIASG é a ferramenta de apoio informatizado que tem o objetivo de oferecer condições adequadas para uma melhor gestão de recursos públicos. Ele é composto de subsistemas de cadastramento de fornecedores, catálogos de materiais e serviço, de divulgação eletrônica de compras, de registro de preços e de gestão de contratos, que auxiliam os gestores na aquisição de bens e contratações de serviços. (FEIJÓ, PINTO e MOTA, 2009).

O desenvolvimento do SIASG tem contemplado mais recentemente a tentativa de aprofundar a exploração das potencialidades da tecnologia em direção à introdução de inovações nos procedimentos de compra, abarcando inclusive a revisão de leis e normas. Um marco nesse sentido foi a criação do portal de compras Comprasnet, na Internet, que permitiu a ampliação do leque de funcionalidades oferecido bem como a forma de acesso. (Fernandes, 2003, p. 17).

O SIASG é um sistema que contempla apenas os órgãos do Poder Executivo, ele age com publicidade e transparência dos atos realizados pela Administração Pública no âmbito das atividades dos serviços gerais, divulgando todas as suas ações no Diário Oficial da União e no site 
de Compras Governamentais. E com isso, disponibiliza à sociedade informações acerca dos processos licitatórios, oferecendo maior clareza dos atos praticados (FEIJÓ, PINTO e MOTA, 2009). Para um menor entendimento, Fernandes (2003) ilustra a estrutura de módulos e funcionalidades do SIASG na tabela a seguir:

Quadro 1 - Estrutura de módulos e funcionalidades do SIASG

\begin{tabular}{|c|c|}
\hline Módulo & Funcionalidades \\
\hline $\begin{array}{l}\text { Cadastro de fornecedores } \\
\text { Sistema de Cadastramento Unificado de } \\
\text { Fornecedores - SICAF } \\
\text { Cadastra e habilita pessoas físicas e jurídicas } \\
\text { interessadas em participar de licitações. }\end{array}$ & $\begin{array}{l}\text { - Pré-cadastramento na Internet. } \\
\text { - Atualização automática com bases de dados de } \\
\text { arrecadação tributária e de contribuições. } \\
\text { - Consulta on line à regularidade fiscal dos fornecedores } \\
\text { em terminal ou Internet. } \\
\text { - Consulta de fornecedores inadimplentes com a União. } \\
\text { - Emissão de boleto bancário para pagamento de taxas } \\
\text { do SICAF. } \\
\text { - Conexão com sites dos órgãos de arrecadação tributária } \\
\text { e de contribuições. }\end{array}$ \\
\hline $\begin{array}{l}\text { Catálogos de materiais e de serviços } \\
\text { Catálogo de Materiais - CATMAT } \\
\text { Catálogo de Serviços - CATSER } \\
\text { Cadastra materiais e serviços conforme padrões } \\
\text { técnicos de descrição e desempenho. }\end{array}$ & $\begin{array}{l}\text { - Consulta à descrição de materiais e serviços. } \\
\text { - Consulta e download de arquivos de linhas de materiais } \\
\text { e serviços. }\end{array}$ \\
\hline $\begin{array}{l}\text { Divulgação eletrônica de editais } \\
\text { Sistema de Divulgação Eletrônica de } \\
\text { Compras - SIDEC } \\
\text { Divulga avisos de licitações no portal de Compras } \\
\text { Governamentais, na Internet e encaminha } \\
\text { publicação no Diário Oficial. }\end{array}$ & $\begin{array}{l}\text { - Registro e consulta a avisos de licitação. } \\
\text { - Registro, consulta e download de editais de licitação. } \\
\text { - Listas preferenciais de informações sobre editais de } \\
\text { licitação. } \\
\text { - Encaminhamento automático de publicações ao Diário } \\
\text { Oficial. } \\
\text { - Registro e consulta a resultados de licitações. }\end{array}$ \\
\hline $\begin{array}{l}\text { Registro de preços praticados } \\
\text { Sistema de Preços Praticados - SISPP } \\
\text { Registra preços praticados nas licitações realizadas. }\end{array}$ & $\begin{array}{l}\text { - Consulta aos preços praticados nas compras mais } \\
\text { recentes de bens ou serviços realizadas pela } \\
\text { Administração Federal. }\end{array}$ \\
\hline $\begin{array}{l}\text { Emissão de ordem de pagamento } \\
\text { Sistema de Minuta de Empenho - SISME } \\
\text { Emite minuta de empenho para pagamento de } \\
\text { compras e contratações, em interligação com o } \\
\text { Sistema Integrado de Administração Financeira - } \\
\text { SIAFI, do Ministério da Fazenda. }\end{array}$ & $\begin{array}{l}\text { - Emissão de minuta de empenho contra recebimento de } \\
\text { mercadoria adquirida. } \\
\text { - Emissão de minuta de empenho com base em } \\
\text { cronograma de desembolso de contrato de serviços ou de } \\
\text { entrega programada de bem. }\end{array}$ \\
\hline $\begin{array}{l}\text { Gestão de contratos } \\
\text { Sistema de Gestão de Contratos - SICON Registra } \\
\text { e acompanha a execução do cronograma físico- } \\
\text { financeiro dos contratos. } \\
\text { Divulga extratos de contratos de prestação de } \\
\text { serviços celebrados pela administração pública } \\
\text { federal com fornecedores, na Internet. }\end{array}$ & $\begin{array}{l}\text { - Registro de contratos celebrados, inclusive de } \\
\text { alterações por Termo Aditivo. } \\
\text { - Registro e consulta a extratos de contratos celebrados, } \\
\text { no Compras governamentais. } \\
\text { - Encaminhamento automático da publicação de extratos } \\
\text { ao Diário Oficial. } \\
\text { - Registro de cumprimento da execução do contrato } \\
\text { (Ateste). } \\
\text { - Emissão automática de ordem de pagamento } \\
\text { (Empenho) }\end{array}$ \\
\hline $\begin{array}{l}\text { Portal de Compras Governamentais } \\
\text { Comprasnet - www.comprasnet.gov.br (Até 2014) }\end{array}$ & $\begin{array}{l}\text { - Acesso na Internet, a informações sobre licitações e } \\
\text { contratações da Administração Pública Federal. }\end{array}$ \\
\hline
\end{tabular}




\begin{tabular}{|c|c|}
\hline $\begin{array}{lc}\text { Compras } & \text { Governamentais } \\
\text { www.comprasgovernamentais.gov.br (Atual) }\end{array}$ & $\begin{array}{l}\text { - Realização de Pregão Eletrônico e Cotação Eletrônica; } \\
\text { apoio à realização de Pregão Presencial. } \\
\text { - Consulta a legislação e normas (Base de legislação, } \\
\text { normas e manuais). } \\
\text { - Utilizacão de extrator de dados (Datawarehouse). }\end{array}$ \\
\hline
\end{tabular}

Fonte: Adaptado de Fernandes (2003, p.90-91)

\subsubsection{Licitações no Brasil como instrumento de políticas públicas}

Quando olhamos as Licitações sob a ótica de instrumento de políticas pública, pensamos nos resultados econômicos, sociais e ambientais que o uso dessa ferramenta pode proporcionar a sociedade. O exemplo de maior destaque em mecanismo de políticas públicas é o Decreto n ${ }^{\circ} 6.204$ de 5 de setembro de 2007 que regulamenta o tratamento favorecido, diferenciado e simplificado para as microempresas e empresas de pequeno porte nas aquisições de bens, serviços e obras, no âmbito da Esfera Pública Federal (BRASIL, 2007). Essa ampliação da participação das microempresas e empresas de pequeno porte nas licitações é uma política pública de distribuição de renda e incentivo dessas empresas.

Outro exemplo que vêm desempenhando papel fundamental na implementação das políticas públicas é o modelo de compras públicas sustentáveis. (CPS), esse tipo de contratação leva em consideração critérios ambientais, econômicos e sociais, em todos os estágios do processo de contratação, o uso de recurso financeiro do Estado passa a ser um aparelho de proteção ao meio ambiente e de desenvolvimento econômico e social. Dessa forma, as contratações públicas mobilizam o setor público a considerar variáveis de sustentabilidade em suas aquisições, e o setor privado a implantar mudanças na direção da ecoeficiência, com uso racional e sustentável dos recursos. (BIDERMAN, 2006).

\subsubsection{Pregão Eletrônico}

O pregão eletrônico atualmente a principal modalidade licitatória, é a forma mais prática pelo fato de ser realizado via uso de tecnologia de informação (internet), respeitando a regulamentação específica, possibilita maior alcance geográfico e garante maior participação de fornecedores e a isonomia na participação. Silveira (2012, p.42) descreve que "Esse novo procedimento aumenta a competição, amplia o número de participantes nos certames e possibilita uma redução de despesas no processo licitatório.” 
Sobre essa modalidade Fonsêca (2006, p.3) expõe que: “O Pregão Eletrônico apresenta sessão pública que se efetiva por meio da utilização de recursos de tecnologia da informação, onde a interação entre os agentes públicos responsáveis pela realização da licitação (Pregoeiro e Equipe de Apoio) e os licitantes / Fornecedores”. Em relação à realização do pregão eletrônico Silveira esclarece que:

O Pregão eletrônico é realizado em sessão pública, via internet, com interveniência dos servidores públicos encarregados dessa função (Pregoeiro e Administrativos) e os participantes do certame numa disputa on-line. $\mathrm{O}$ acesso aberto a qualquer pessoa do início ao fim do pregão torna o procedimento totalmente transparente. $\mathrm{O}$ pregoeiro deve ter sido treinado para exercer esta função, pois, nesse processo, ele substitui as tradicionais comissões de licitação. (SILVEIRA, 2012, p.43).

O Decreto $n^{\circ} 5.450$, de 31 de Maio de 2005, em seu artigo $30^{\circ}$ estabelece que o processo licitatório será instruído com os seguintes documentos:

I. Justificativa de contratação;

II. Termo de referência;

III. Planilhas de custo, quando for o caso;

IV. Previsão de recursos orçamentários, com a indicação das respectivas rubricas;

V. Autorização de abertura da licitação;

VI. Designação de pregoeiro e equipe de apoio;

VII. Edital e respectivos anexos, quando for o caso;

VIII. Minuta do termo do contrato ou instrumento equivalente, ou minuta da ata de registro de preços, conforme o caso;

IX. Parecer jurídico;

X. Documentação exigida para a habilitação;

XI. Ata contendo os seguintes registros: a) licitantes participantes; b) propostas apresentadas; c) lances ofertados na ordem de classificação; d) aceitabilidade da proposta de preço; e) habilitação e f) recursos interpostos, respectivas análises e decisões;

XII. Comprovantes das publicações: a) aviso do edital; b) do resultado da licitação; c) do extrato do contrato; e d) dos demais atos que seja exigida a publicidade, conforme o caso. (BRASIL, 2005).

Todos os atos licitatórios realizados pelo órgão promotor da licitação, bem como pregoeiros, equipe de apoio do pregão e licitantes, pertinentes ao pregão eletrônico, quais sejam: publicação, credenciamentos, propostas, sessões públicas, lances, negociações, recursos, adjudicações e homologações, são realizados exclusivamente pelo sistema eletrônico no site 
https://www.comprasgovernamentais.gov.br o portal de compras governamentais do Governo Federal, o qual também divulga para sociedade, por meio do Diário Oficial, todas as informações referentes as licitações realizadas, dando maior lisura e transparência ao procedimento.

\subsubsection{Sistema de Registro de Preços}

O Sistema de Registro de Preços é previsto no artigo 15, inciso II, da Lei 8.666/93, onde diz que "As compras sempre que possível deverão ser processadas através do sistema de registro de preços" (BRASIL, 1993). O Decreto no 7.892 de 23 de janeiro de 2013 o regulamenta e institui em seu artigo $4^{\circ}$, o procedimento de Intenção de Registro de Preços - IRP, que será operacionalizado pelo Sistema de Administração de Serviços Gerais - SIASG, para registro e divulgação dos itens a serem licitados. (BRASIL, 2013).

O Sistema de Registro de Preços - SRP é a junção de atos para registro formal de preços relativos à contratação de serviços ou aquisição de bens a serem contratados em momento cabível pela Administração Pública. Ele é diferente das contratações convencionais no objeto da licitação. No sistema convencional, a licitação tem o objetivo selecionar fornecedor e proposta para contratação específica, concretizada pela Administração ao final do procedimento. No registro de preços, a licitação tem como finalidade selecionar fornecedor e proposta para contratações não específicas, que poderão ser realizadas, por repetidas vezes, durante o período de validade. (NUNES e DANTAS, 2012).

Jacoby Fernandes (2008, p.31) define o Sistema de Registro de Preços como "um procedimento especial de licitação que se efetiva por meio de uma concorrência ou pregão sui generis, selecionando a proposta mais vantajosa, com observância do princípio da isonomia, para eventual e futura contratação da Administração."

Corroborando com as definições anteriores, Justen Filho (2005, p.144) atesta que: “O registro de preços é um contrato normativo, constituído como um cadastro de produtos e fornecedores, selecionados mediante licitação, para contratações sucessivas de bens e serviços, respeitados lotes mínimos e outras condições previstas em edital”.

É importante ressaltar que o Sistema de registro de preços não é uma modalidade de licitação e sim uma forma de realizar aquisições de bens e contratações de serviços de modo parcelado, e que a Administração não tem obrigação em contratar quaisquer itens registrados. 
O Decreto $\mathrm{n}^{\mathrm{o}} 7.892 / 2013$ em seu artigo $3^{\circ}$ define as hipóteses legais que permitem a Administração Pública utilizar o SRP, são elas:

I - quando, pelas características do bem ou serviço, houver necessidade de contratações frequentes;

II - quando for conveniente a aquisição de bens com previsão de entregas parceladas ou contratação de serviços remunerados por unidade de medida ou em regime de tarefa;

III - quando for conveniente a aquisição de bens ou a contratação de serviços para atendimento a mais de um órgão ou entidade, ou programas de governo; e

IV - quando, pela natureza do objeto, não for possível definir previamente o quantitativo a ser demandado pela Administração. (BRASIL, 2013a).

O mesmo Decreto em seu artigo $7^{\circ}$ estabelece que a licitação para registro de preços, será realizada na modalidade de concorrência ou na modalidade de pregão e será precedida de ampla pesquisa de mercado. Não será exigida a indicação da dotação orçamentária, só na fase de assinatura do contrato ou outro instrumento hábil. $\mathrm{O}$ artigo $12^{\circ}$ reza sobre a validade da ata de registro de preços que não será superior a doze meses, incluídas eventuais prorrogações. (BRASIL, 2013a).

Os órgãos envolvidos em um Sistema de Registro de Preços são classificados em três grupos, quais são:

Órgão gerenciador: órgão ou entidade da administração pública federal responsável pela condução do conjunto de procedimentos para registro de preços e gerenciamento da ata de registro de preços;

Órgão participante: órgão ou entidade da administração pública federal que participados procedimentos iniciais do Sistema de Registro de Preços e integra a ata de registro de preços; e

Órgão não participante (Carona): órgão ou entidade da administração pública que, não tendo participado dos procedimentos iniciais da licitação, atendidos os requisitos estabelecidos no Decreto n..$^{\circ}$ 7.892/13, faz adesão à ata de registro de preços. (BRASIL, 2013b, p.3, grifo nosso).

As etapas a serem realizadas antes da utilização de licitação para o SRP devem ser precedidas da fase de planejamento, seguida dos passos:

- Identificar as necessidades do órgão por meio de levantamento de informações;

- Dimensionar quantitativamente e especificar qualitativamente essas necessidades; 
- Verificar as contratações semelhantes em exercícios anteriores e a possibilidade de padronização;

- Verificar a contratação e as necessidades da Administração atendem aos requisitos para utilização do SRP previstos no art. $3^{\circ}$ do Decreto 7.892/2013.

- Identificar em qual das hipóteses do art. $3^{\circ}$ do Decreto 7.892/2013 estaria enquadrada a adoção do SRP.

- Verificar se há órgãos interessados em participar da licitação para registro de preços, utilizando, preferencialmente, a Intenção de Registro de Preços - IRP. (CONTROLADORIA GERAL DA UNIÃO, 2014).

A Controladoria Geral da União - CGU em sua cartilha de perguntas e respostas sobre o Sistema de Registro de Preços (2014) afirma que dentre as vantagens em se utilizar o SRP destacam-se as seguintes:

- Evolução significativa da atividade de planejamento organizacional, motivando a cooperação entre as mais diversas áreas;

- Possibilidade de maior economia de escala, atendendo o princípio da economicidade;

- Aumento da eficiência administrativa;

- Otimização dos processos de contratação de bens e serviços da Administração;

- A solicitação de fornecimento ocorre somente quando surgir a necessidade em adquirir;

- Ausência de obrigatoriedade em se adquirir os bens e serviços registrados, em suas quantidades totais ou parciais;

- Vinculação do particular pelo prazo de validade da ata às quantidades e preços registrados;

- O orçamento é disponibilizado apenas no momento da contratação;

- Celeridade da contratação, haja vista que se tem preços registrados;

- Atendimento as demandas imprevisíveis;

- Possibilita a participação de pequenas e médias empresas;

- Redução do estoque, custo de armazenagem e perda de material;

- Maior eficiência logística;

- Possibilidade de controle social, conforme a publicidade dada a todo o trâmite. (CONTROLADORIA GERAL DA UNIÃO, 2014).

Para incluir um Pregão Eletrônico por Sistema de Registro de Preços, é necessária a inclusão da Intenção de Registro de Preços - IRP que é um procedimento operacionalizado dentro do SIASG, acessado pelo Portal de Compras Governamentais, ele possibilita aos órgãos que tem interesse em realizar a licitação para registro de preços de um determinado bem ou serviço divulgar a intenção dessa compra para o restante da Administração Pública Federal, para que os interessados registrem, previamente, as quantidades individuais a serem contratadas, e com isso fazer a junção das demandas de órgãos e entidades federais para a contratação de itens comuns, potencializando a economia nas compras públicas. Para além da economicidade, esse procedimento tem também o objetivo de estimular o planejamento das aquisições e com isso diminuir o número de adesões a atas de registro de preços. (CONTROLADORIA GERAL DA UNIÃO, 2014). 


\subsubsection{Adesão a Atas de Registro de Preços - Figura do Carona}

A adesão a atas de registro de preços é um procedimento polêmico e controverso. De acordo com a opinião de parte da doutrina a figura do "carona" viola o princípio da obrigatoriedade de licitar, previsto no artigo $37^{\circ}$ da Constituição Federal. Jacoby Fernandes (2006, p.1) ressalta que, "Esse procedimento vulgarizou-se sob a denominação de carona que traduz em linguagem coloquial a ideia de aproveitar o percurso que alguém está desenvolvendo para concluir o próprio trajeto, sem custos.” Ao discorrer sobre o “carona”, Marçal Justen Filho (2010) leciona que:

Em síntese, "carona" consiste na contratação fundada num sistema de registro de preços em vigor, mas envolvendo uma entidade estatal dele não participante originalmente, com a peculiaridade de que os quantitativos contratados não serão computados para $o$ exaurimento do limite máximo. (JUSTEN FILHO, 2010, p. 207).

Já o entendimento de Paulo Sérgio de Monteiro Reis (2008, p. 4) sobre o “carona” é que:

O "carona" é, dessa forma, um órgão/entidade da Administração que não participou da licitação para registro de preços, nem como gerenciador, tampouco como participante. Em determinado momento, precisando adquirir um bem ou contratar um serviço comum, a Administração, em estando obrigada a, nos termos do ordenamento jurídico vigente, realizar licitação, poderá evitar esse procedimento aderindo a uma Ata de Registro de Preços que esteja dentro do seu prazo de validade. (REIS, 2008, p. 4).

Joel de Menezes Niebuhr (2006, p. 1) delineia a figura do "carona" como sendo:

Em termos práticos: a entidade "A" promove licitação para registro de preços com o propósito de adquirir 500 computadores. A empresa vencedora assina a ata de registro de preços e, pois, compromete-se a fornecer à entidade "A" os 500 computadores, nos termos do que fora licitado. $O$ carona consiste na possibilidade de uma outra entidade, entidade "B", que não teve qualquer relação com o processo de licitação realizado, aderir à ata de registro de preços da entidade "A" e adquirir com base nela também 500 computadores. Assim sendo, o fornecedor venderá 500 computadores para a entidade "A", que promoveu a licitação, e outros 500 computadores para a entidade "B", que não teve qualquer relação com a licitação outrora realizada. (NIEBUHR, 2006, p.1).

O Tribunal de Contas da União por meio do Acórdão nº 1.487/07 censurou a prática do "carona" e determinou que o Ministério do Planejamento, Orçamento e Gestão (MPOG) que reexaminasse os limites para adesão ao SRP, pois o TCU considerou que um "mercado paralelo de 
aquisição de bens e serviços sem licitação, incompatível com o princípio da competitividade e ensejando ao fornecedor registrado lucro excessivo com relação aos quantitativos previstos." (PEREIRA JÚNIOR e DOTTI, 2012, p. 555).

Em outubro de 2012, a Corte Federal de Contas julgou o referido pedido de reexame impetrado pelo MPOG, negando provimento ao pedido e reconhecendo a conexão da matéria do Acórdão n ${ }^{\circ}$ 1.487/2007 e demais julgados com a nova orientação referente ao "carona". Ato contínuo, o Tribunal fixou prazo (31 de dezembro de 2012), a partir do qual o limite à adesão indiscriminada às Atas passou a ser obrigatório. (CARVALHAES, 2013, p.5).

Não obstante, é importante salientar que a Adesão a Atas de Registro de Preços está resguardada legalmente pelo artigo $22^{\circ}$ e parágrafos, Decreto 7.892/2013, que revogou o Decreto 3.931/2001 e instituiu limites a adesão indiscriminada, estabelecendo em seu parágrafo $4^{\circ}$ que no instrumento de convocatório deverá prever que os quantitativos decorrentes das adesões, não podendo exceder, na totalidade, ao quíntuplo do quantitativo de cada item registrado na ata de registro de preços, para o órgão gerenciador e os participantes, independentes do número de “caronas" que aderirem. (BERTOLDO et. al, 2015).

Nunes e Dantas (2012) esclarecem que o Tribunal de Contas da União não foi contrário ao procedimento de Adesão a Atas de Registro de Preços por órgãos não participantes, apenas não condescende com o procedimento de adesões ilimitadas, recomendando aos órgãos da Administração Pública o cuidado necessário para que essa prática seja compatível com os princípios constitucionais que norteiam as compras públicas.

A legislação brasileira esclarece que, a adesão ao Sistema de Registro de Preços - SRP poderá ser utilizada por qualquer órgão ou entidade da administração pública federal, que não seja participante da licitação (carona), obedecendo às condições estabelecidas no artigo $22^{\circ}$ do Decreto n $7.892 / 2013$, quais são: justificar comprovadamente a vantagem da adesão, a ata estar vigente, da prévia consulta e anuência do órgão gerenciador quanto à adesão, dos limites de quantitativo do objeto, da aceitação, pelo fornecedor, quanto à contratação pretendida, das condições previstas no Edital. (BERTOLDO et. al, 2015).

A adesão do "carona" é composta de algumas fases. Sendo que, previamente verifica-se a vantagem, validade e compatibilidade da Ata de Registros de Preços a qual se pretende aderir. Logo após, solicita-se a autorização e a intervenção do órgão gestor para negociar com o fornecedor 
sua "participação". O fornecedor então definirá as condições de preço e fornecimento e, contanto que isso não prejudique as obrigações já assumidas, poderá aceitar ou não, fornecer o bem ou prestar o serviço. (DIAS et. al, 2012, p.3).

Pereira Junior e Dotti (2012) esclarecem que a opção pela adesão a Ata de Registro de Preços pelo órgão não participante (carona), deverá acatar alguns pressupostos:

a) A identidade do objeto (bens e serviços);

b) Os bens e serviços registrados deverão ser aptos a satisfazer as necessidades dos órgãos caronas;

c) Os preços devem ser de mercado, segundo apurado em ampla pesquisa;

d) Justificativa necessária que a contratação por adesão é economicamente a mais vantajosa;

e) Manifestação de interesse junto ao órgão gerenciador;

f) Resposta do órgão gerenciador sobre a adesão;

g) Interesse do fornecedor em atender ao pedido;

h) Ausência de prejuízo quanto às obrigações assumidas anteriormente pelo fornecedor perante os órgãos ou entidades participantes e o gerenciador.

Jacoby Fernandes (2008) explana que, as ideias centrais que sustentam a validade do Sistema de Registro de Preços e do sistema de "carona" consistem na desnecessidade de repetição de um processo oneroso, lento e desgastante quando já alcançada à proposta mais vantajosa. Além disso, quando o carona adere a uma Ata de Registro de Preços, em vigor, normalmente já tem do órgão gerenciador - órgão que realizou a licitação para o Sistema de Registro de Preços informações adequadas sobre o desempenho do contratado na execução do ajuste. É importante salientar que a licitação é um procedimento prévio a um contrato e quanto menos tempo e custo consumir mais eficiente é o processo. 


\section{METODOLOGIA E PROCEDIMENTOS}

\subsection{Tipo e descrição geral da pesquisa}

Essa pesquisa tem caráter descritivo, que, de acordo com (GIL, 2008) tem como objetivo, descrever as características de determinadas populações ou fenômenos. Uma de suas particularidades está no emprego de técnicas padronizadas de coleta de dados, tais como o questionário e a observação sistemática. Em seu escopo, ela pode ser caracterizada como um estudo de caso, que, conforme PONTE (2006, p. 2) significa:

"É uma investigação que se assume como particularística, isto é, que se debruça deliberadamente sobre uma situação específica que se supõe ser única ou especial, pelo menos em certos aspectos, procurando descobrir a que há nela de mais essencial e característico e, desse modo, contribuir para a compreensão global de um certo fenômeno de interesse."

Na visão de Gil (2010), os estudos de caso demandam o emprego de várias técnicas de coleta de dados, o que assegura a investigação necessária à pesquisa e a inclusão do caso no todo, bem como permite maior confiabilidade aos resultados. O presente estudo teve a coleta de dados dividida em duas etapas: a primeira parte foi realizada através da coleta de dados nas fontes secundárias, como livros, periódicos, leis e bases de dados; a segunda parte abrange a coleta de dados das fontes primárias, que forneceram análises para posterior criação de informações.

Com o intuito de contribuir com o desenvolvimento da pesquisa e enriquecer as constatações obtidas, escolheu-se utilizar pesquisa bibliográfica na definição dos conceitos usados na pesquisa, bem como no estudo de outros trabalhos sobre compras públicas. Para tal, foram realizadas consultas a livros, teses, dissertações, artigos científicos e demais materiais disponíveis.

Na pesquisa documental, foram analisadas 186 atas de registro de preços e a mesma quantidade de editais, além de relatórios eletrônicos, a coleta de dados foi realizada através do uso da ferramenta de consulta do Sistema Integrado de Administração de Serviços Gerais (SIASG) junto ao portal www.comprasgovernamentais.gov.br nas opções Painel de Compras e consulta de licitações e atas de pregões, levantando dados do ano de 2014, referentes ao volume total de recursos utilizado pelo IFEs do Centro Oeste em processos de compras, nas modalidades: 
Concorrência, Tomada de Preços, Pregão Presencial e Eletrônico, Dispensa e Inexigibilidade de Licitação.

Como forma de auferir o percentual de economia obtido nas contratações será aplicada a fórmula de economicidade, levando-se em consideração o valor estimado (VE) e o valor efetivamente contratado/homologado (VC), assim como a eficiência das compras (data da homologação - data da apresentação das propostas).

Com a análise dos dados coletados é possível obter o Índice de Economia que representa a variação percentual entre o valor estimado para o pregão e o valor contratado; e o Índice de Eficiência Temporal, que demonstra o tempo entre a realização e homologação dos pregões durante a fase externa. O cálculo dos índices é alcançado utilizando: $\mathrm{IE}=\{1-(|\mathrm{VC}-\mathrm{VE}|) / \mathrm{VE}\}$, onde: IE é o Índice de Economia; VE - Valor de Estimado; VC - Valor Contratado (homologado); e IA = DH - DR, onde: IA é o Índice de Eficiência temporal; DH - Data da Homologação; DR - Data da Realização (CAMPOS, 2014). Para que as análises comparativas sejam realizadas, será utilizada a escala econômica contida na tabela abaixo:

Tabela 1. Escala de economia

\begin{tabular}{ll}
\hline Índice de Economia & Classificação \\
\hline 0 a 0,20 & Pouco Econômica \\
\hline $\mathbf{0 , 2 1}$ a 0,40 & Econômica \\
\hline 0,41 a 0,60 & Muito Econômica \\
\hline 0,61 a 0,99 & Excelência em Economia \\
\hline Fonte: $($ Campos, 2014, p.42). &
\end{tabular}

A análise tem como finalidade organizar e sumarizar os dados de forma a possibilitar o fornecimento de respostas ao problema proposto na investigação (GIL, 1999). Conforme Santos (2007), a análise dos dados consiste em encontrar um significado para os dados coletados e em explicar como eles respondem ao problema de pesquisa formulado progressivamente. A figura abaixo demonstra organizou-se o delineamento dessa Pesquisa. 
Figura 1 - Delineamento da Pesquisa

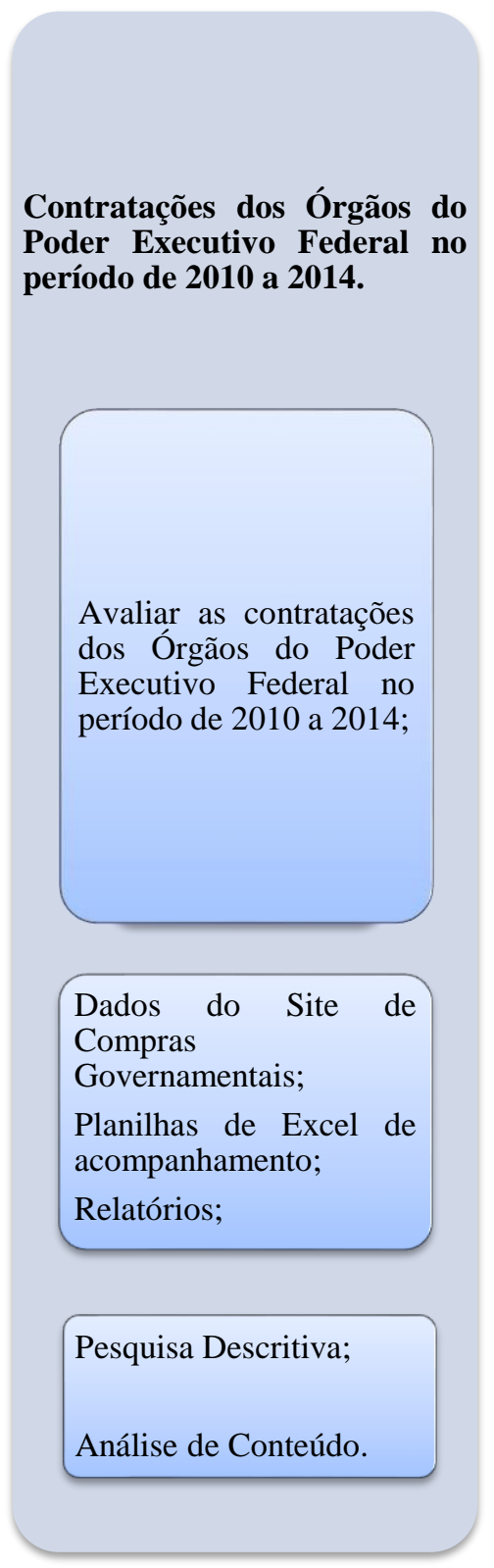

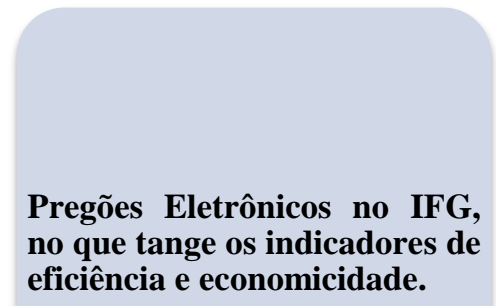

Analisar o uso do Pregão Eletrônico no IFG, no exercício de 2014, no tocante aos critérios economicidade eficiência temporal.

Aplicação dos cálculos do Índice de Economia e do Índice de Eficiência Temporal.

Análise Econômica dos dados.

\section{Análise comparativa das compras realizadas nos Institutos Federais da Região Centro Oeste.}

Analisar comparativamente as compras modalidades: Tomadas de Preços, Concorrência, Pregão Presencial e Eletrônico, Dispensa Inexigibilidade Licitação nos Institutos Federais de Educação da Região Centro Oeste.

Análise das situações causais entre os dados da pesquisa empírica e os das bibliográfica documental. pesquisas

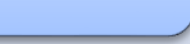

Análise de Conteúdo.

Fonte: Próprio Autor.

\section{2 - Caracterização das Instituições analisadas.}

A história dos Institutos Federais de Educação, Ciências e Tecnologia iniciou-se em 1909, com a criação da Escola de Aprendizes Artífices para o ensino profissional, primário e gratuito, por meio do Decreto $\mathrm{n}^{\circ}$ 7.566, em 23 de agosto daquele ano, assinado pelo Presidente da República, Nilo Peçanha (BRASIL, 1909). Para Cunha essas escolas tinham como finalidade: 
A formação de operários e contramestres, mediante ensino prático e conhecimentos técnicos necessários aos menores que pretendessem aprender um ofício, em "ofícinas de trabalho manual ou mecânico que forem mais convenientes e necessários ao estado em que funcionar a escola, consultadas, quanto possível, as especialidades das indústrias locais. (Cunha, 2000, p.63).

A história dessas escolas tem caráter inicial voltado para o social, como consta no Decreto de criação:

Considerando: que o aumento constante da população das cidades exige que, se facilitem às classes proletárias os meios de vencer as dificuldades sempre crescentes da luta pela existência: que para isso se torna necessário, não só o preparo técnico e intelectual, como fazê-los adquirir hábitos de trabalho profícuo, que os afastará da ociosidade ignorante, escola do vício e do crime, que é um dos primeiros deveres do Governo da República formar cidadãos úteis à Nação. (BRASIL, 1909).

No período de 1930 a 1940, durante o governo do então Presidente Getúlio Vargas, com a promulgação da Constituição de 1937, o ensino técnico foi visto como um fator primordial para o desenvolvimento da classe trabalhadora, e, como elemento estratégico para a formação de mão de obra qualificada. Essa Constituição transformou as Escolas de Aprendizes Artífices em Liceus Industriais, a fim de trabalhar conjuntamente com a expansão industrial. Conforme o artigo 37:

Art. 37. A Escola Normal de Artes e Offícios Wenceslào Braz e as escolas de aprendizes artífices, mantidas pela União, serão transformadas em lyceus, destinados ao ensino profissional, de todos os ramos e graos.

Paragrapho único. Novos lyceus serão instituídos, para propagação do ensino profissional, dos vários ramos e graos, por todo o território do País. (BRASIL, 1937).

Em 1942, o Ministro da Educação e Saúde, Gustavo Capanema, numa reforma no Sistema Educacional Brasileiro, criou o Decreto Lei no 4.073, de 30 de janeiro de 1942, Lei Orgânica do Ensino Industrial, equiparando o ensino profissional tecnológico ao nível médio, fazendo com que os Liceus Industriais passassem a se chamar Escolas Industriais e Técnicas (EITs).

As Escolas Industriais e Técnicas (EITs) prevaleceram até o ano de 1959, no governo do Presidente Juscelino Kubitschek, quando foram transformadas em Escolas Técnicas Federais (ETFs), ganhando autonomia administrativa e pedagógica. (BRASIL, 2011). 
Iniciaram-se então as transformações de algumas Escolas Técnicas Federais em Centros Federais de Educação Tecnológica, com a Lei n. ${ }^{\circ}$ 6.545, de 30 de Junho de 1978. Conforme consta no artigo $1^{\circ}$ da referida Lei:

Art. $1^{\circ}$ - As Escolas Técnicas Federais de Minas Gerais, com sede na Cidade de Belo Horizonte; do Paraná, com sede na Cidade de Curitiba; e Celso Suckow da Fonseca, com sede na Cidade do Rio de Janeiro, criadas pela Lei n. ${ }^{\circ} 3.552$, de 16 de Fevereiro de 1959, alterada pelo Decreto Lei n. ${ }^{\circ}$ 796, de 27 de Agosto de 1969, autorizadas a organizar e ministrar cursos de curta duração de Engenharia de Operação, com base no Decreto-Lei n. ${ }^{\circ}$ 547, de 18 de Abril de 1969, ficam transformadas em Centros Federais de Educação Tecnológica. (BRASIL, 1978).

Essa mudança aconteceu aos poucos, a partir da Lei $\mathrm{n}^{\circ}$ 8.948, de 08 de dezembro de 1994, entretanto, cada instituição teria seu decreto específico para transformação em CEFET. A primeira fase da expansão da Rede Federal de Educação Profissional e Tecnológica aconteceu em 2005, no governo do então presidente Luis Inácio Lula da Silva, com a publicação da Lei 11.195, criando novas unidades de ensino, em parceria com Estados, Municípios e Distrito Federal.

No ano de 2008, a partir da Lei n. ${ }^{\circ}$ 11.892, de 29 de Dezembro, foi instituída a Rede Federal de Educação Profissional, Científica e Tecnológica, criando os Institutos Federais de Educação, Ciência e Tecnologia, foi quando ocorreu a transformação dos Centros Federais de Educação Tecnológica de Goiás (CEFET/GO) em Instituto Federal de Goiás, formaram-se duas novas instituições: Instituto Federal de Goiás - IFG e Instituto Federal Goiano - IF Goiano.

O Instituto Federal de Goiás é uma autarquia federal com autonomia administrativa, patrimonial, financeira, didático-pedagógica e disciplinar, equiparado às universidades federais. Uma instituição que vai desde a educação básica e profissional, básica e profissional, pluricurricular e multicampi, até a educação superior e pós-graduação, especialista na oferta de educação profissional e tecnológica nas diferentes modalidades de ensino. Tem por objetivo, formar e qualificar profissionais para os diversos setores da economia, bem como realizar pesquisas e promover o desenvolvimento tecnológico de novos processos, produtos e serviços, em estreita articulação com os setores produtivos e com a sociedade, oferecendo mecanismos para a educação continuada. (IFG, 2013).

A comunidade acadêmica soma atualmente mais de vinte mil alunos, distribuídos entre os quatorze campi em pleno funcionamento: Águas Lindas, Anápolis, Aparecida de Goiânia, Cidade 
de Goiás, Formosa, Goiânia Oeste, Goiânia, Inhumas, Itumbiara, Jataí, Luziânia, Senador Canedo, Uruaçu, Valparaíso.

A organização geral do IFG é formada pelos Colegiados, Comissões Permanentes, Reitoria e Campi. A Reitoria sediada em Goiânia, Capital do Estado, é composta pelo Gabinete do Reitor, Diretoria Executiva e as Pró-Reitorias de Administração, Desenvolvimento Institucional, Ensino, Pesquisa e Pós-Graduação e Extensão.

O IF Goiano surgiu da fusão dos CEFETs de Rio Verde, Urutaí e Escola Agrotécnica Federal de Ceres, todos originários de antigas escolas agrícolas. Como órgão de administração central, o IF Goiano tem uma Reitoria instalada em Goiânia. Em 2010, a Instituição implantou mais um campus em Iporá e em 2014 iniciou atividades em três novos campus, em Campos Belos, Posse e Trindade. Além destes, a Instituição também possui quatro campus avançados, nas cidades de Catalão, Cristalina, Ipameri e Hidrolândia, totalizando doze unidades em Goiás e atendendo atualmente a mais de seis mil alunos de diversas localidades. (BRASIL, 2015a).

O Instituto Federal de Brasília - IFB é composto por uma Reitoria e 10 unidades distribuídas pelo Distrito Federal: Brasília, Ceilândia, Estrutural, Gama, Planaltina, Riacho Fundo, Samambaia, São Sebastião, Taguatinga e Taguatinga Centro. Atendendo mais de 10500 alunos, sendo mais de 6000 presenciais e 4000 na modalidade de ensino à distância. Conta com cinco Pró-Reitorias: de Ensino, de Pesquisa e Inovação, de Extensão, de Administração e de Desenvolvimento Institucional. (BRASIL, 2015b).

A junção das três autarquias - Cefet Mato Grosso (em Cuiabá), o Cefet Cuiabá (em São Vicente) e Escola Agrotécnica Federal de Cáceres - criou o Instituto Federal de Mato Grosso (IFMT), que desde então, em um processo de expansão e interiorização, alcançou diversas outras localidades, e conta atualmente com 14 campi em funcionamento (Alta Floresta, Barra do Garças, Cáceres, Campo Novo do Parecis, Confresa, Cuiabá - Octayde Jorge da Silva, Cuiabá - Bela Vista, Juína, Pontes e Lacerda, Primavera do Leste Rondonópolis, São Vicente, Sorriso e Várzea Grande). Possui ainda três campus avançados, nos municípios de Diamantino, Lucas do Rio verde e Tangará da Serra. Atendendo aproximadamente 25 mil alunos, nos mais de 100 cursos distribuídos nos níveis: Pós-graduação, Superior, Técnico (com ensino médio integrado, subsequente, concomitante e Proeja), Educação a Distância, além de cursos de curta duração, como Formação Inicial e Continuada, Mulheres Mil e PRONATEC. (BRASIL, 2015c). 
Em 2008 o IFMS foi criado com a previsão de instalação dos campus Campo Grande e Nova Andradina, já no ano seguinte, o novo projeto de expansão da Rede Federal consolidou o caráter regional de atuação do IFMS com a construção de outros cinco campus nos municípios de Aquidauana, Corumbá, Coxim, Ponta Porã e Três Lagoas. O Campus Nova Andradina foi o primeiro a entrar em funcionamento, no ano de 2010, os outros seis campus iniciaram as atividades de ensino em 2011. Três anos após foram implantadas novas unidades nos municípios de Dourados, Jardim e Naviraí. (BRASIL, 2015d). 


\section{RESULTADOS E DISCUSSÃO}

\subsection{Contratações dos Órgãos do Poder Executivo Federal no período de 2010 a 2014.}

Ao longo dos últimos anos, as contratações públicas do Poder Executivo Federal vêm crescendo em valores financeiros e diminuindo em números de processos, o que pode demonstrar que está se comprando mais como menor dispêndio com processos licitatórios, isso evidencia também que há uma melhora no planejamento das compras pelos órgãos gestores.

O procedimento administrativo dispensa de licitação foi o mais utilizado nessas contratações, representando $73 \%$ do total dos processos de compras. É importante salientar que, essas aquisições são regulamentadas pela Lei no 8.666/93, e possibilita à Administração Pública a compra de bens e serviços pela modalidade de contratação direta, mediante licitação dispensável.

Comparando as modalidades, o pregão foi o segundo mais utilizado no período, atingindo a média anual de aproximadamente 35 mil processos os quais são em sua maioria do tipo eletrônico, alcançando $99 \%$ dos processos, enquanto que o presencial apenas $1 \%$ das contratações. Quanto ao tipo de aquisições os certames licitatórios de serviços responderam por 52\% dessas contratações e a aquisição de bens materiais $48 \%$ do total licitado. A tabela abaixo demonstra a evolução das compras públicas do Poder Executivo Federal no período de 2010 a 2014, fazendo um recorte na modalidade de estudo que é o Pregão Eletrônico.

Tabela 2. Evolução das contratações públicas do Poder Executivo Federal, no período de 2010 a 2014. Total em Milhões.

\begin{tabular}{|c|c|c|c|c|c|c|c|c|}
\hline \multirow[t]{2}{*}{ Ano } & \multirow[t]{2}{*}{ Total em R\$ Milhões } & \multirow[t]{2}{*}{$\begin{array}{c}\mathrm{N}^{\mathbf{0}} \\
\text { Processos }\end{array}$} & \multirow[t]{2}{*}{$\begin{array}{c}N^{\circ} \text { Processos } \\
\text { MEC }\end{array}$} & \multirow[t]{2}{*}{$\begin{array}{c}\mathbf{N}^{\mathbf{o}} \\
\text { Pregões }\end{array}$} & \multicolumn{2}{|c|}{ Tipo de Pregão \% } & \multicolumn{2}{|c|}{$\begin{array}{c}\text { Tipo de Aquisições } \\
\%\end{array}$} \\
\hline & & & & & Eletrônico & Presencial & Serviço & Material \\
\hline 2010 & 45.054 & 211560 & 220298 & 58487 & 98,4 & 1,6 & 53 & 47 \\
\hline 2011 & 39.380 & 183183 & 103247 & 28108 & 98,9 & 1,1 & 53 & 47 \\
\hline 2012 & 68.858 & 174217 & 95531 & 29292 & 99,0 & 1,0 & 55 & 45 \\
\hline 2013 & 52.739 & 164022 & 94563 & 30625 & 99,3 & 0,7 & 54 & 46 \\
\hline 2014 & 76.508 & 148861 & 85440 & 28404 & 99,4 & 0,6 & 55 & 45 \\
\hline Total & 282.540 & 881843 & 599079 & 174916 & 99,0 & 1,0 & 52 & 48 \\
\hline
\end{tabular}

De todos os Órgãos do Executivo Federal, o Ministério de Educação foi o que mais comprou nesse período, totalizando $68 \%$ do montante de processos de aquisições. Os dados apresentados referem-se às contratações federais dos Órgãos do Poder Executivo entre os meses 
de janeiro e dezembro dos últimos cinco anos. As informações foram extraídas do Portal de Compras Governamentais, utilizando a opção Painel de Compras gerenciadas pelo Ministério do Planejamento, Orçamento e Gestão.

\subsection{Contratações dos Institutos Federais de Educação, Ciência e Tecnologia da Região Centro Oeste no ano de 2014.}

A pesquisa englobou a análise das contratações públicas dos cinco Institutos Federais de Educação da Região Centro Oeste Brasileira: IFG, IF Goiano, IFB, IFMS e o IFMT. A intenção da pesquisa é analisar comparativamente as compras públicas do IFG em relação às outras instituições pesquisadas, no que tange a economicidade e eficiência temporal. A Tabela 3 demonstra o montante de compras realizado pelos órgãos estudados nas modalidades de contratações mais utilizadas.

Tabela 3. Volume de compras por Instituição Federal de Ensino, expresso em R\$ Mil.

\begin{tabular}{lcccccc}
\hline Modalidade & IFG & IF Goiano & IFB & IFMT & IFMS & Total Geral \\
\hline Tomada de Preços & - & - & - & 2.883 & - & 2.883 \\
\hline Concorrência & 9.465 & 9.382 & - & 5.694 & - & 24.541 \\
\hline Pregão & & & & & & 129.565 \\
\hline Dispensa & 36.035 & 28.801 & 1.177 & 49.600 & 13.952 & 10.981 \\
\hline Inexigibilidade & 2.984 & 3.721 & 17 & 3.616 & 643 & 4.303 \\
\hline Total Geral & 718 & 290 & 1.175 & 1.641 & 479 & 172.074 \\
\hline Fonte: www.comprasgovernamentais.gov.br & & & & & \\
\hline
\end{tabular}

O montante movimentado pelas cinco instituições pesquisadas, no exercício de 2014 foi da ordem de aproximadamente R $\$ 172.273$ milhões. O IFMT responsável por 37\% do total dessas compras, o IFG ficou com $29 \%$ da fatia, $24 \%$ no IF Goiano, o IFMS com 9\% e o IFB com apenas 1\%. Com a coleta desses dados foi apurado que a maior parte dos recursos aplicados nas compras foi por pregão, abrangendo $75 \%$ do total, ou seja: R\$ 129.565 milhões, a concorrência conseguiu a fatia de 14\%, dispensa de licitação atingiu $6 \%$, e, a modalidade tomada de preços e a inexigibilidade ficam cada uma com $2 \%$ do total das compras públicas. 
Observa-se que as instituições analisadas priorizaram monetariamente o mesmo procedimento administrativo licitatório, a modalidade Pregão eletrônico, que de acordo com Fernandes (2008), é atualmente a mais utilizada, pois proporciona maior concorrência, permite selecionar a proposta mais vantajosa à administração pública, e é considerada a mais transparente, econômica e célere para as contratações públicas.

A Tabela 4 demonstra o quantitativo de processos por modalidade, sendo que a dispensa de licitação foi o procedimento com mais números de processos com 67\%, seguindo-se da inexigibilidade de licitação com $32 \%$ do total geral de processos. É importante salientar que, essas aquisições são regulamentadas pela Lei nº 8.666/93, e possibilita à Administração Pública a compra de bens e serviços pela modalidade de contratação direta, mediante licitação dispensável. O pregão eletrônico representa $10 \%$ do quantitativo total de processos, enquanto que a concorrência e tomada de preços somaram juntas apenas $1 \%$ do montante de certames realizados.

Analisando a tabela 3 no quesito volume de despesas por modalidade e comparando-a com a tabela 4 que demonstra o número de processos por modalidade, observa-se que com o uso do pregão eletrônico é possível adquirir um volume maior de itens ou serviços em um número menor de processos, evitando o fracionamento de despesas, possibilitando a escolha da proposta mais vantajosa e diminuindo os custos processuais.

O único órgão que utilizou a modalidade tomada de preços foi o IFMT. Essa mesma instituição foi quem mais fez o uso das modalidades pregão, com 35\% e inexigibilidade com $70 \%$ do total realizado. O IF Goiano foi o órgão que mais realizou processos nas modalidades concorrência, com $70 \%$ do total e da modalidade dispensa de licitação com $43 \%$ do montante efetivado.

Tabela 4. Quantidade de processos de compras por modalidade no ano 2014.

\begin{tabular}{|c|c|c|c|c|c|c|}
\hline \multirow[t]{2}{*}{ IFES } & \multicolumn{5}{|c|}{ Modalidade } & \multirow[b]{2}{*}{ Total Geral } \\
\hline & Tomada de Preços & Pregão & Concorrência & Inexigibilidade & Dispensa & \\
\hline IFG & 0 & 25 & 2 & 20 & 29 & 76 \\
\hline IF Goiano & 0 & 54 & 19 & 76 & 435 & 584 \\
\hline IFB & 0 & 14 & 0 & 53 & 21 & 88 \\
\hline IFMT & 8 & 65 & 5 & 404 & 425 & 907 \\
\hline IFMS & 0 & 25 & 1 & 23 & 91 & 140 \\
\hline Total Geral & 8 & 183 & 27 & 576 & 1001 & 1795 \\
\hline
\end{tabular}

Fonte: www.comprasgovernamentais.gov.br

Elaborado pelo próprio autor. 
É de surpreender o montante de dispensas de licitação realizadas pelo IF Goiano, da ordem de R \$ 3.721 milhões no total de 435 processos e pelo IFMT, somando R \$ 3.616 milhões em 425 processos, conforme as tabelas 3 e 4 . Essa situação é preocupante, pois mesmo a legislação permitindo o uso dessa modalidade, ela repreende o uso extensivo, pois além de ser menos econômica e facilitar o uso do favorecimento, também pode configurar fracionamento de despesas e ausência de planejamento por parte da gestão.

O escopo de nossa pesquisa são as despesas realizadas com aquisição de materiais e serviços no ano 2014, que movimentaram em torno de $\mathrm{R} \$ 244.680$ milhões em todas as modalidades de compras. Essas despesas estão demonstradas no Gráfico 1. A aquisição de serviços foi a mais utilizada, superando a contratação de bens em todas as instituições pesquisadas, isso se justifica pela necessidade de contratação de prestadores de serviços para atender as demandas fixas como fornecimento de energia elétrica, água tratada, telefonia/dados, segurança/vigilância, limpeza e conservação, motorista, entre outros serviços necessários ao bom funcionamento dos órgãos públicos.

Gráfico 1: Despesas com materiais e serviços em 2014, em R\$ mil.

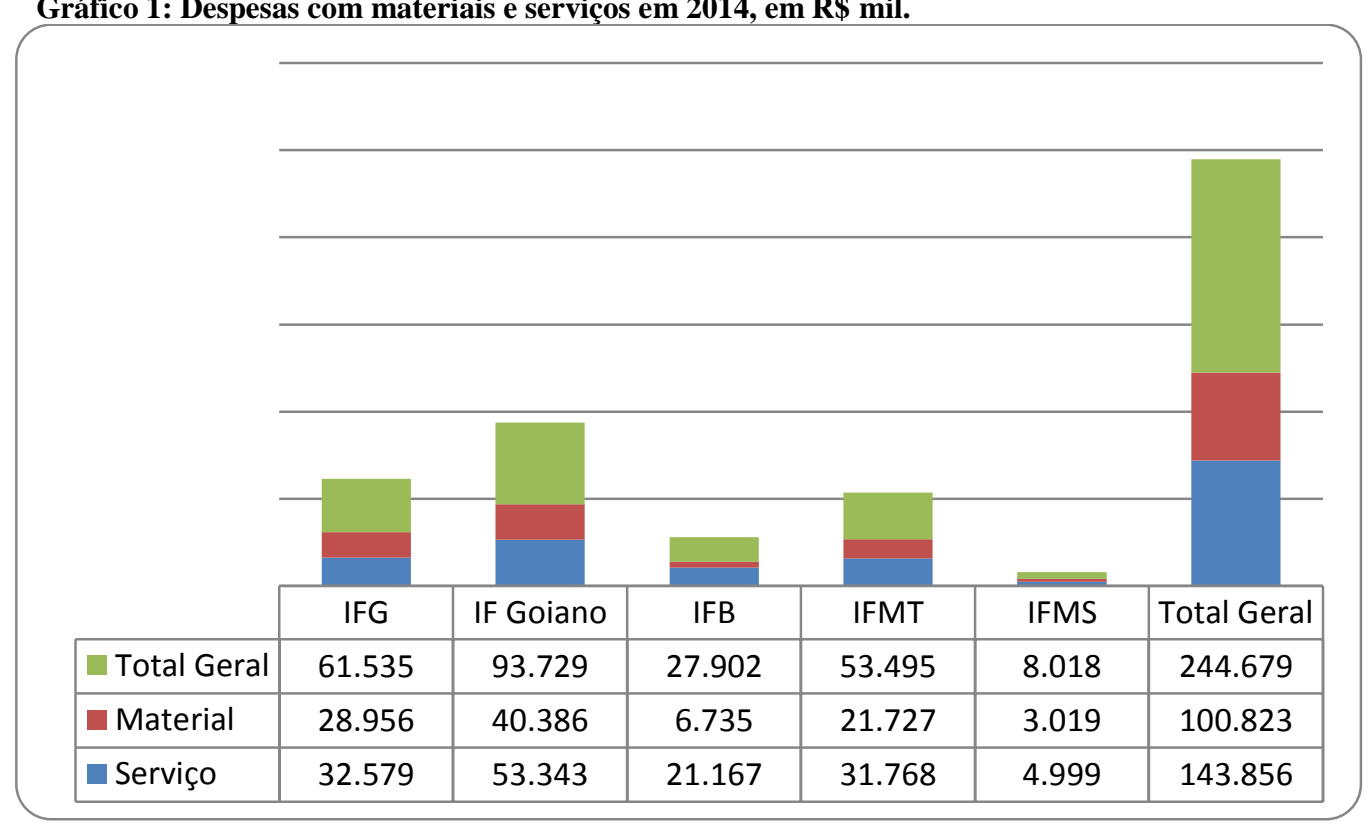

Fonte: www.comprasgovernamentais.gov.br

Elaborado pelo próprio autor.

O Gráfico 2 demonstra a análise econômica obtida nas contratações de serviços e aquisição de materiais realizadas por meio de pregão eletrônico. No caso das demais modalidades 
de licitação não há como analisar, pois não é informado no sistema de compras do governamentais o valor estimado para aquisições. Ficando esses dados disponíveis apenas nos processos físicos.

A economicidade corresponde a uma análise de otimização de custos para os melhores benefícios, sendo assim, uma das dimensões da eficiência. A eficiência administrativa pode então ser entendida como a procura da otimização da gestão com vistas à obtenção dos melhores resultados com os menores custos possíveis. (BINENBOJM, 2008).

Gráfico 2: Economia nas aquisições de materiais e serviços em 2014, em R\$ mil.

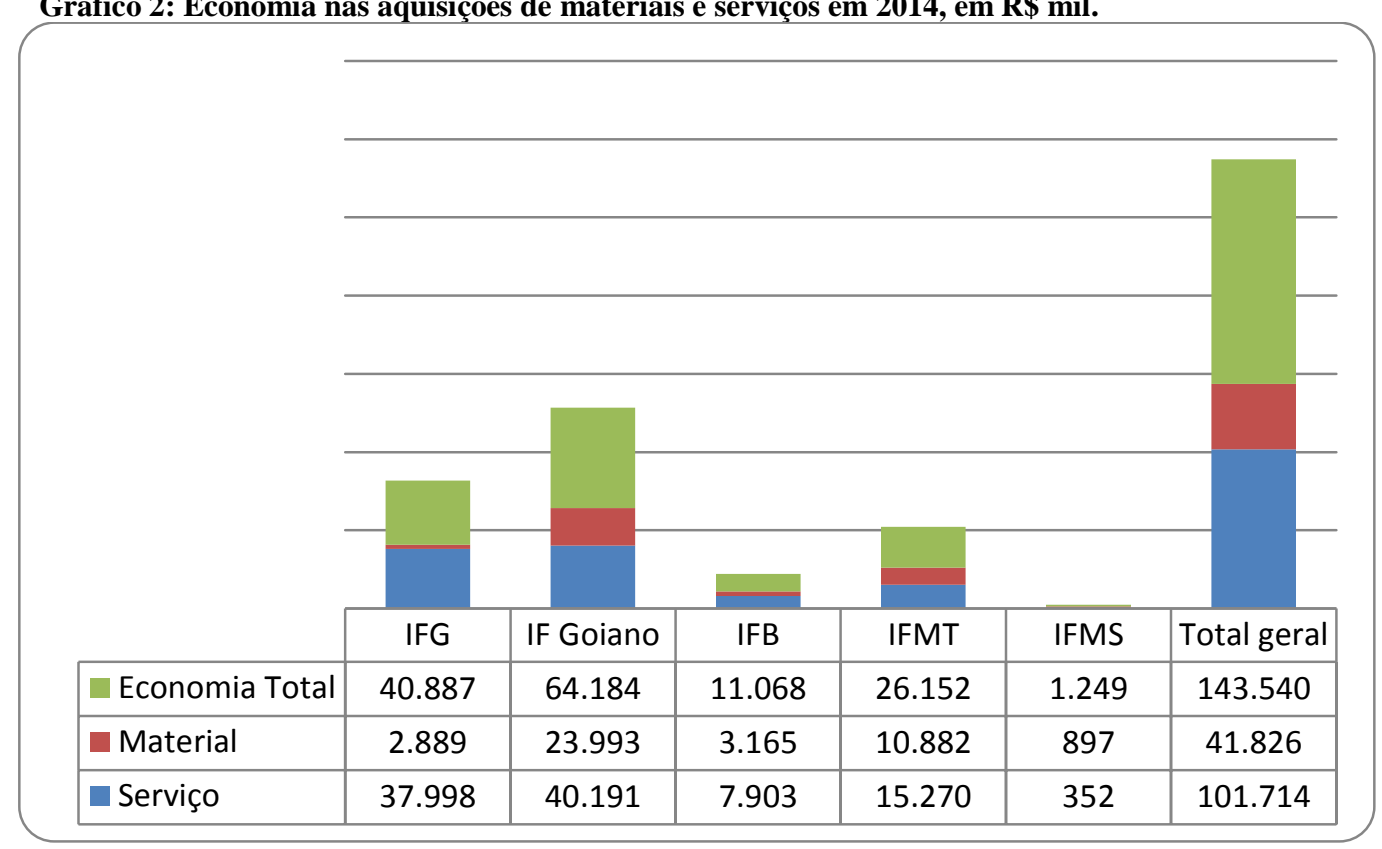

Fonte: www.comprasgovernamentais.gov.br

Elaborado pelo próprio autor.

A cerca da economia obtida nas aquisições de matérias e serviços no ano de 2014, o IF Goiano, em sua totalidade de compras realizadas por pregão eletrônico, avaliou gastar R \$ 157.912 Milhões, entretanto contratou R\$93.729 Milhões, conseguindo uma economia de R \$ 64.184 milhões, que representa $45 \%$ de economicidade. O IFG estimou gastar R 102.423 milhões, entretanto contratou R $\$ 61.535$ milhões, alcançando uma economia de R \$ 40.887 milhões, que representa $28 \%$ de economicidade. O IFB demonstrou $8 \%$ de economicidade, o IFMT impetrou uma economia de $18 \%$ e, por fim o IFMS conseguiu um índice de $1 \%$ de economicidade.

A economicidade para o grupo de despesa: aquisição de serviços atingiu $71 \%$ do total, o que corresponde monetariamente a R 101.704 milhões economizados. O IF Goiano foi quem mais 
economizou com $\mathrm{R} \$ 40.191$ milhões, seguido do IFG que atingiu $\mathrm{R} \$ 37.998$ milhões. A economia para o grupo de despesa: aquisição de materiais alcançou $29 \%$ do total, o que corresponde financeiramente a $\mathrm{R} \$ 41.826$ milhões economizados. O IF Goiano novamente foi quem mais economizou com $\mathrm{R} \$ 23.993$ milhões, seguido do IFMT que alcançou $\mathrm{R} \$ 10.882$ milhões.

O Índice de Economicidade representa a variação percentual entre o valor estimado para a contratação e o valor homologado do pregão. Esse índice foi calculado a partir dos dados coletados no site de compras governamentais, para que seja realizada a análise comparativa entre o IFG e os demais Institutos analisados. Todas as Instituições analisadas apresentaram o Índice de Economia acima de 0,61, que de acordo com Campos (2014) representa excelência em economia.

O gráfico 3, calcula a eficiência temporal que é o tempo médio gasto pelo pregoeiro desde a abertura da proposta até a homologação do pregão. Considerando os dados obtidos, as Instituições que obtiveram melhor média de dias despendidos nos processos de compras foram o IF Goiano e o IFMT, com 11 e 21 dias respectivamente. O IFMS gastou 35 dias em média, enquanto que o IFG e IFB tiveram a mesma média de 39 dias.

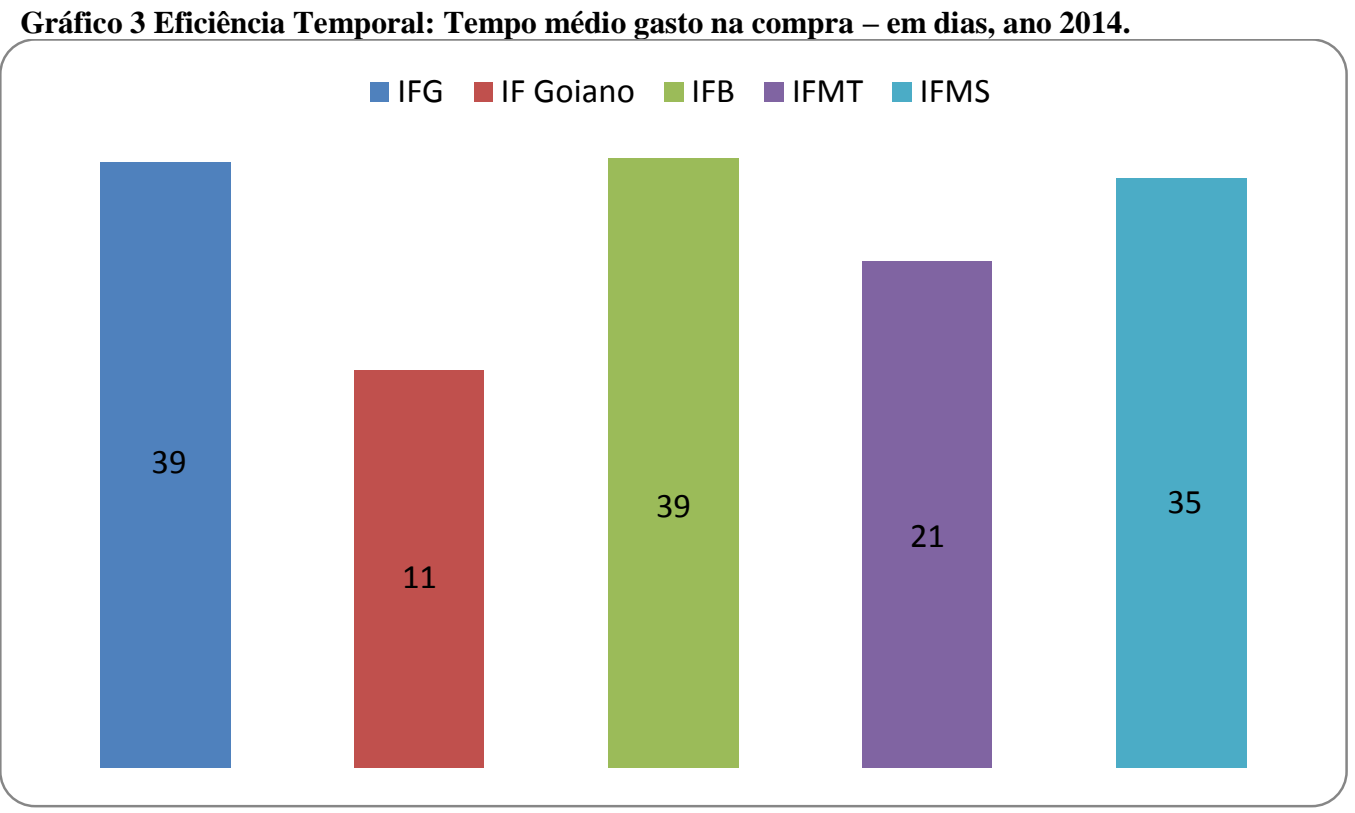

Fonte: www.comprasgovernamentais.gov.br

Elaborado pelo próprio autor

O indicador eficiência temporal revelou uma grande assimetria entre as instituições, essa disparidade pode estar ocorrendo pela influência de fatos pontuais à execução dos processos de 
aquisições, como: não utilização do modelo de compras compartilhadas, falta de padronização dos itens no sistema de cadastro de serviços e materiais do Site do Compras Governamentais, déficit de pessoal no setor de compras e licitações, demora das análises dos processos no Setor Jurídico, falta de comunicação entre o setor demandante e o setor de licitações. Aqui há forte indicativo de que devem ser aprofundados estudos para entender os motivos que estão entravando os seus processos de compras do IFG, IFB e IFMS. Por outro lado, interessante também seria investigar as boas práticas que levam o IF Goiano e o IFMT a serem mais eficientes no quesito analisado.

Tabela 5. Escala de economia por processo.

\begin{tabular}{lcccc}
\hline Órgão & $\begin{array}{c}\text { Economia Total } \\
\text { Em R } \mathbf{\$} \text { Mil }\end{array}$ & $\begin{array}{c}\mathbf{N}^{\mathbf{0}} \text { de processos } \\
\text { Unidade }\end{array}$ & $\begin{array}{c}\text { Economia por } \\
\text { processo } \\
\text { Em R } \mathbf{M i l}\end{array}$ & $\begin{array}{c}\text { Eficiência Temporal } \\
\text { Em dias }\end{array}$ \\
\hline IFG & 40.888 & 76 & 538 & 39 \\
\hline IF Goiano & 64.183 & 584 & 109 & 11 \\
\hline IFB & 11.069 & 88 & 125 & 39 \\
\hline IFMT & 26.150 & 907 & 28 & 21 \\
\hline IFMS & 1.250 & 140 & 8 & 35 \\
\hline Total Geral & $\mathbf{1 4 3 . 5 4 0}$ & $\mathbf{1 7 9 5}$ & 79 & Média - 29 \\
\hline
\end{tabular}

Fonte: www.comprasgovernamentais.gov.br

Elaborado pelo próprio autor

Considerando a economia obtida por processo, o IFG foi a instituição que economizou o maior valor por número de processo, ou seja, para cada pregão realizado conseguiu-se economizar em torno de $\mathrm{R} \$ 538$ mil reais. Isso concorda em muito com a Lei $\mathrm{n}^{\mathrm{o}}$ 8.666/93 em seu artigo 25, quando diz que a competitividade do pregão eletrônico proporciona os agentes públicos realizarem negócios mais vantajosos financeiramente.

É importante salientar que o IFG foi o órgão que teve o menor número de processos realizados, tendo assim um custo por processo menor que as demais instituições, isso dar-se pela prática de compras compartilhadas que é utilizada na instituição. Esse método é empregado com a intenção de diminuir os custos processuais e evitar que aconteçam vários pregões com o mesmo objeto de contratação. 


\section{CONCLUSÕES E RECOMENDAÇÕES.}

As conclusões da pesquisa, apontam que todas as Instituições estudadas atingiram o Índice de excelência de economia, contribuindo com a meta do Governo que é o aproveitamento ótimo dos recursos disponíveis para a utilização máxima de dos resultados almejados, ou seja, comprar mais por menos. Quanto melhor for realizada a previsão e o planejamento das compras públicas, maior será a eficiência, eficácia e economicidade, uma vez que o ato de planejar as aquisições proporciona o menor uso de recursos administrativos, humanos e materiais, diminuindo os custos processuais, evitando o fracionamento de despesa, permitindo maior aproveitamento dos bens e serviços.

Observou-se que o Pregão eletrônico, o foco da pesquisa, foi a modalidade de licitação que órgãos pesquisados mais realizou dispêndio financeiro, representando $75 \%$ do total das aquisições. As demais modalidades não disponibilizam no portal eletrônico do governo, todos os dados necessários à pesquisa, dificultando a análise dos índices de economicidade e eficiência temporal. Outra limitação desse trabalho foi a falta dos dados de algumas unidades gestoras no painel de compras do site compras governamentais, talvez pelo fato delas não serem unidades descentralizadas, com autonomia para instrução processual e elaboração das licitações.

Embora haja uma discrepância nos índices de economicidade na aquisição de bens e serviços, os dados apontam que, na média, o Instituto Federal Goiano foi o que conseguiu o melhor resultado, que representa $45 \%$ de economicidade, seguindo com um percentual de $28 \%$, o Instituto Federal de Goiás. Enquanto que o Instituto Federal do Mato Grosso obteve uma economia de 18\%, o Instituto Federal de Brasília demonstrou 8\%, e, por fim o Instituto Federal do Mato Grosso do Sul conseguiu um índice de $1 \%$ de economicidade. A discrepância entre os índices representa um campo fértil para ao aprofundamento de pesquisas com foco na criação de incentivos que gerem maior eficiência no processo de compras públicas.

A aquisição de serviços superou a contratação de bens em todas as instituições pesquisadas, isso se justifica pela necessidade de contratação de prestadores de serviços para atender as demandas fixas como fornecimento de energia elétrica, água tratada, telefonia/dados, segurança/vigilância, limpeza e conservação, motorista, entre outros serviços demandados para o bom funcionamento dos órgãos. Quando estudamos a economia na aquisição de serviços, observa- 
se que esse grupo de despesa atingiu $71 \%$ do total economizado. Os Institutos que se destacaram foi o IF Goiano com 39\%, seguido do IFG que atingiu 37\% de economia nas contratações de serviços.

Já na análise da economia na aquisição de materiais, alcançou-se $29 \%$ do total de compras homologadas, o que corresponde financeiramente a $\mathrm{R} \$ 41.826$ milhões economizados. O IF Goiano novamente foi quem mais economizou atingindo $57 \%$, em seguida o IFMT que alcançou $26 \%$ do total economizado.

Considerando os dados obtidos em relação à eficiência temporal observou-se uma grande assimetria. As instituições que obtiveram melhor média de dias despendidos nos processos de compras foram o IF Goiano e o IFMT, com 11 e 21 dias respectivamente. O IFMS gastou 35 dias em média, enquanto que o IFG e IFB tiveram a mesma média de 39 dias.

Essa disparidade pode estar ocorrendo pela influência de fatos pontuais à execução dos processos de aquisições, como: não utilização do modelo de compras compartilhadas, falta de padronização dos itens no sistema de cadastro de serviços e materiais do Site do Compras Governamentais, déficit de pessoal no setor de compras e licitações, demora das análises dos processos no Setor Jurídico, falta de comunicação entre o setor demandante e o setor de licitações. Esse desvio de mais de três vezes merece ser estudado. Aqui há forte indicativo de que devem ser aprofundados estudos para entender os motivos que estão entravando os seus processos de compras do IFG, IFB e IFMS. Por outro lado, interessante também seria investigar as boas práticas que levam o IF Goiano e o IFMT a serem mais eficientes no quesito analisado.

Considerando a economia obtida por processo, o IFG foi a instituição que economizou o maior valor por número de processo, ou seja, para cada pregão realizado conseguiu-se economizar em torno de $\mathrm{R} \$ 538$ mil reais. Isso concorda em muito com a Lei no 8.666/93 em seu artigo 25, quando diz que a competitividade do pregão eletrônico proporciona os agentes públicos realizarem negócios mais vantajosos financeiramente.

O IFG foi o órgão que teve o menor número de processos realizados, tendo assim um custo por processo menor que as demais instituições, isso dar-se pela prática de compras compartilhadas que é utilizada na Instituição, que proporciona ganho de escala e preços menores. Evitando que aconteçam vários pregões com o mesmo objeto de contratação, diminuindo assim os custos processuais. Sugere-se que os órgãos que ainda não utilizam o modelo de compra 
compartilhada, comecem a fazer uso dessa ferramenta de aprimoramento do planejamento de contratações públicas. 


\section{REFERÊNCIAS}

ADDISON, E. E. Os Princípios que regem a Administração Pública: Sua Construção Doutrinária e Jurisprudencial. $1^{\circ}$ ed. Florianópolis: UFSC, 2009. 135 p.

BAILY, P. et al. Compras: princípios e administração, São Paulo: 8 ed., Editora Atlas, 2000.

BALEEIRO, A. Uma introdução à ciência das finanças. 14. ed. rev. atual. por Flávio Bauer Novelli. Rio de Janeiro: Forense, 1996.

BERTOLDO, E. C. et al. (Orgs.). Licitações, contratos administrativos, pregão eletrônico e presencial - leis complementares, Curitiba, 18. ed., Editora Negócios Públicos do Brasil, 2015.

BIDERMAN, R. et al. (Orgs.). Guia de compras públicas sustentáveis: uso do poder de compra do governo para a promoção do desenvolvimento sustentável. Rio de Janeiro: Editora Fundação Getúlio Vargas, 2006. 136 p.

BINENBOJM, G. In: Temas de Direito Administrativo e Constitucional. 2008, p. 346.

BOUERI, R.; Avaliando a Eficiência do Gasto Público. In: Boueri, R; Saboya, M. (Org.). Aspectos do Desenvolvimento Fiscal. Brasília: IPEA, 2007, v. 1, p. 105-109.

BLUMENSCHEIN, F. Estratégias de Compras Governamentais no Brasil-Teoria dos Leilões e" Big Data", v.21, p. 1 - 32, 2014

BRAGA, A. L. et al. Pregão Eletrônico: O Novo Aliado da Administração Pública para Redução de Custos e Garantia da Transparência - Estudo de Caso do Banco do Brasil, Região Sudeste e Distrito Federal. Rio de Janeiro, Universidade Federal Rural do Rio de Janeiro, artigo, 13 f, 2006.

BRASIL, Constituição (1937). Constituição dos Estados Unidos do Brasil. Rio de Janeiro, RJ, 1937."Disponívelem:">http://www.planalto.gov.br/ccivil_03/Constituicao/Constitui\%C3\%A7ao 37.htm">Acesso em: 05 abr. 2015.

. Constituição (1998). Constituição Federativa do Brasil. Brasília, DF: Senado Federal: Centro Gráfico, 1998. 292 p. 
Decreto $N^{\circ} 4.342$ de 23 de agosto de 2002 - Altera dispositivos do Decreto $\mathrm{n}^{\mathrm{o}} 3.931$, de 19 de setembro de 2001, que regulamenta o Sistema de Registro de Preços previsto no art. 15 da Lei $n^{\circ}$ 8.666, de 21 de junho de 1993, e dá outras providências. Diário Oficial [da] República Federativa do Brasil, Poder Executivo, Brasília, DF,26, ago. 2002. Disponível em: http://www.planalto.gov.br. Acesso em: 05 abr. 2015.

Decreto $n^{0}$ 5.450/2005. Regulamenta o pregão, na forma eletrônica, para aquisição de bens e serviços comuns, e dá outras providências. Disponível em 101< http://www.planalto.gov.br/ccivil_03/_ato2004-2006/2005/decreto/d5450.htm> Acesso em: 02 maio 2015.

.Decreto n. ${ }^{\circ}$ 6.204, de 5 de setembro de 2007. Regulamenta o tratamento favorecido, diferenciado e simplificado para as microempresas e empresas de pequeno porte nas contratações públicas de bens, serviços e obras, no âmbito da administração pública federal. Disponível em <http://www.planalto.gov.br>. Acesso em: 01 abr. 2015.

Decreto n. ${ }^{\circ}$ 7.566, de 23 de setembro de 1909. Cria nas capitais dos Estados da República Escolas de Aprendizes e Artífices para o ensino profissional primário e gratuito. Disponível em: http://portal.mec.gov.br/setec/arquivos/pdf3/decreto_7566_1909.pdf. Acesso em: 11 abr. 2015.

Decreto $n^{\mathbf{0}}$ 7.892, de 23 de janeiro de 2013. Regulamenta o Sistema de Registro de Preços previsto no art. 15 da Lei no 8.666, de 21 de junho de 1993. Diário Oficial da União, Brasília, DF, 23 jan. 2013. Disponível em <http://www.planalto.gov.br>. Acesso em: 29 abr. 2015.

Surgimento das escolas técnicas. Portal Brasil. 2011.Disponível em:

<http://www.brasil.gov.br/educacao/2011/10/surgimento-das-escolas-tecnicas > Acesso em: 02 mar. 2015.

Histórico do IF Goiano. Portal Brasil. 2015. Disponível em:

<https://www.ifgoiano.edu.br/home/index.php/historico> Acesso em: 28 dez. 2015.

IFB em números.Portal Brasil. 2015. Disponível em: 〈http://ifbemnumeros.ifb.edu.br> Acesso em 28 dez. 2015. 
IFSP. "Manual para contratação direta - Adesão/carona/sistema de registro de preços", 2013, São Paulo: Disponível. em: <http:www.ifsp.gov.br/manuais>.Acesso em: 05 abr. 2015.

Apresentação e Histórico do IFMT. Portal Brasil. 2015. Disponível em:

$<$ http://ifmt.edu.br/conteudo/pagina/apresentacao-e-historico> Acesso em 28 dez 2015.

. Apresentação e Histórico do IFMS. Portal Brasil. 2015. Disponível em:

<http://www.ifms.edu.br/leftsidebar/ifms/acesso-a-informacao/informacoes-classificadas >Acesso em 28 dez. 2015.

Ministério do Planejamento, Orçamento e Gestão - Secretaria de Orçamento Federal. "Manual Técnico Orçamentário", Versão 2015, Brasília: Disponível em:<http://www.orcamentofederal.gov.br/informacoesorcamentarias/manualtecnico/mto_2015_1a_edicao-150514.pdf $>$ Acesso em: 05 abr 2015.

. LEI No 4.320, de 17 de março de 1964, Institui Normas Gerais de Direito Financeiro para elaboração e controle dos orçamentos e balanços da União, dos Estados, dos Municípios e do Distrito Federal. Diário Oficial [da] República Federativa do Brasil, Poder Executivo, Brasília, DF, 04, mai. 1964. Disponível em:http://www.planalto.gov.br. Acesso em: 08 mar. 2015.

Lei $n^{\circ}$ 6.545, de 30 de junho de 1978. Diário Oficial [da] República Federativa do Brasil, Poder Executivo, Brasília, DF, 22, jun. 1993. Disponível em: <http://www.planalto.gov.br/CCIVIL/leis/L6545.htm.> Acesso em: 05 abr. 2015.

Lei No 8.666, de 21 de junho e 1993. Regulamenta o art. 37, inciso XXI, da Constituição Federal, institui normas para licitações e contratos da Administração Pública e dá outras providências. Diário Oficial [da] República Federativa do Brasil, Poder Executivo, Brasília, DF, 22, jun. 1993. Disponível em: <http://www.planalto.gov.br.> Acesso em: 08 mar. 2015.

. Lei n ${ }^{\circ} 8.948$, de 08 de dezembro de 1994, Dispõe sobre a instituição do Sistema Nacional de Educação Tecnológica e dá outras providências, Diário Oficial [da] República Federativa do Brasil, Poder Executivo, Brasília, DF, 09, dez. 1993. Disponível em: <http://www.planalto.gov.br/ccivil_03/lEis/L8948.htm> Acesso em: 08 mar. 2015.

. Lei $\mathrm{N}^{\mathrm{o}} 10.520$ de 17 de julho de 2002, institui no âmbito da União, Estados, Distrito Federal e Municípios, nos termos do art. 37, inciso XXI, da Constituição Federal, modalidade de 
licitação denominada pregão, para aquisição de bens e serviços comuns, e dá outras providências. Diário Oficial [da] República Federativa do Brasil, Poder Executivo, Brasília, DF, 18, jul. 2002. Disponível em: <http://www.planalto.gov.br.> Acesso em: 05 abr. 2015.

Lei n ${ }^{0} 11.892$, de 29 de Dezembro de 2008, que institui a Rede Federal de Educação Profissional, Científica e Tecnológica, cria os Institutos. Federais de Educação, Ciência e Tecnologia, e dá outras providências. Diário Oficial [da] República Federativa do Brasil, Poder Executivo, Brasília, DF, 30, dez. 2008. Disponível em: <http://www.planalto.gov.br.> Acesso em: 05 abr. 2015.

Ministério da Fazenda. Secretaria do Tesouro Nacional. Receitas públicas: manual de procedimentos: aplicado à União, Estados, Distrito Federal e Municípios / Ministério da Fazenda, Secretaria do Tesouro Nacional - Brasília: Secretaria do Tesouro Nacional, Coordenação-Geral de Contabilidade, 2005. 177 p.

BRESSER-PEREIRA, L. C. A reforma da administração pública. In: .Crise econômica e reforma do Estado no Brasil : para uma nova interpretação da América Latina. São Paulo: Editora 34, 1996. p. 269-294.

CAMPOS, S. J. de A. Compras Públicas: estudo de caso da Universidade de Brasília. Brasília, Universidade de Brasília, Dissertação, 73 f, 2014.

CARVALHAES, R.de O. Limites à adesão indiscriminada à ata de registro de preços: estudo sob o enfoque do acórdão ${ }^{\circ} 1.233 / 2012$ do tribunal de contas da união e da nova regulamentação introduzida pelo decreto federal no 7.892/2013. Advocacia Geral da União. Brasília, DF, Disponível em: <www.agu.gov.br/page/download/index/id/18003860 >Acessado em: 10 maio 2015.

CARVALHO, D. Orçamento e contabilidade pública: teoria, prática e mais de 800 exercícios. 6.ed. Rio de Janeiro: Campus, 2014.

CONTROLADORIA GERAL DA UNIÃO. Sistema de Registro de Preços: Perguntas e Respostas. Brasília: 2014. Disponível em: < http://www.cgu.gov.br/Publicacoes/auditoria-efiscalizacao/arquivos/sistemaregistroprecos.pdf >.Acesso em 12 de Maio de 2015.

CUNHA, L. A. O Ensino de Ofícios Artesanais e Manufatureiros no Brasil Escravocrata. São Paulo: Editora UNESP, Brasília, DF: Flacso, 2000. 
DECLARAÇÃO dos direitos do homem e do cidadão 1789. Biblioteca virtual de direitos humanos. Disponível em: <http://www.direitoshumanos.usp.br/index.php/Documentosanteriores-\%C3\%A0-cria\%C3\%A7\%C3\%A3o-da-Sociedade-das-Na\%C3\%A7\%C3\%B5esat\%C3\%A9-1919/declaracao-de-direitos-do-homem-e-do-cidadao-1789.html> Acesso em: 01 mar. 2015.

DIAS, H. A. de S. Sistema de registro de preços: aspectos controvertidos da figura do "carona". Revista do Tribunal de Contas do Estado de Minas Gerais. Belo Horizonte, n. 3, p. 249-269, Jul/ago/set. 2012.

DI PIETRO, M. S. Z. Direito Administrativo. 14 ed. São Paulo: Atlas, 2002 . Direito administrativo. 17 ed. São Paulo: Altas, 2004. - 27 edição - São Paulo: Atlas, 2014.

FARIA, E. R. et al. Fatores determinantes na variação dos preços dos produtos contratados por pregão eletrônico. Revista de Administração Pública. Rio de Janeiro, ano 44, n. 6, p. 1405 1428, nov/dez. 2010.

FEIJÓ, P. H. PINTO, L. F. MOTA, F. G. L. Curso de Siafi: Uma abordagem prática da execução Orçamentária e financeira: $2^{a}$ ed. Brasília 2009.

FERNANDES, C. C. Sistemas de compras eletrônicas e sua aplicação à administração pública - o caso do SIASG/ComprasNet. Rio de Janeiro: FGV, 2003.

FERNANDES, J. U. J. Sistema de registro de preço e pregão presencial e eletrônico. Belo Horizonte: Fórum, 2008.

Carona em sistema de registro de preços: uma opção inteligente para redução de custos e controle, 2006. Disponível em: <http://www.jacoby.pro.br/Carona.pdf.> Acesso em: 12 de maio. 2015.

FONSÊCA, A. R. F. Pregão Eletrônico: uma análise de sua evolução histórica - legislativa e das inovações decorrentes do decreto $n^{\circ}$. 5.450/2005. O Pregoeiro, Pregão - História e Economicidade, Curitiba, nº 06, p.30-33, março. 2006. 
FROSSARD, L. B. de M. Desafios da eficiência no contexto da gestão de compras de medicamentos em hospital público: o caso do Hospital das Forças Armadas-HFA. 2012.

GASPARINI, Diogenes. Direito administrativo. 13. ed. São Paulo: Saraiva, 2008.

GIACOMONI, J. Bases normativas do plano plurianual: análise das limitações decorrentes da ausência de lei complementar. Revista de Administração Pública, Rio de Janeiro, v. 38, n. 1, p. 79-91, jan./fev. 2004.

GIL, A. C. Métodos e técnicas de pesquisa social. São Paulo: Atlas, 1999.

Como elaborar projetos de pesquisa. $4^{\text {a }}$ ed. São Paulo: Atlas, 2008.

, $5^{\text {a }}$ ed., São Paulo: Atlas, 2010.

GOMES, C. R. de M. Manual de Direito Financeiro e Finanças. 2. ed. ver. e amp. Brasília: Brasília Jurídica, 2000.

IFG, Carta de Serviços ao Cidadão; Goiânia; IFG, 2013.

IURCONVITE, Adriano dos Santos. O Princípio da Legalidade na Constituição Federal. Universo Jurídico, Juiz de Fora, ano XI, 28 de ago. de 2006.Disponível em: <http://uj.novaprolink.com.br/doutrina/2647/O_PRINCIPIO_DA_LEGALIDADE_NA_CONSTI TUICAO_FEDERAL >. Acesso em: 14 abr. 2015

JUSTEN FILHO, M. Comentários à Lei de Licitações e Contratos Administrativos. 11. ed. São Paulo: Dialética. 2005.

Comentários à lei de licitações e contratos administrativos. 14. ed. São Paulo:

Dialética, 2010.

MAIA, A. et al. A importância da melhoria da qualidade do gasto público no Brasil:

Propostas práticas para alcançar este objetivo. In: II Congresso CONSAD de Gestão Pública, Painel. 2007. 
MATIAS-PEREIRA, José. Curso de Administração Pública: foco nas instituições e ações governamentais. $3^{\mathrm{a}}$ ed. São Paulo: Atlas, 2010.

MEIRELLES, H. L. Mandado de Segurança, ação popular, ação civil pública, mandado de injunção, habeas data. $18^{a}$ ed. atual. São Paulo. Revista dos Tribunais, 1997.

Direito administrativo brasileiro. 24ª ed. São Paulo: Malheiros Editores, 1999. 34. ed. São Paulo: Malheiros Editores, 2008.

MELLO, C. A. B. de, Curso de Direito Administrativo. $20^{\mathrm{a}}$ ed. ver. e atual. até a Emenda Constitucional. São Paulo. Malheiros. 2006

25. ed. São Paulo: Malheiros, 2008.

MENEZES, F. M. Uma introdução à teoria de leilões. Brazilian Review of Econometrics, v. 14, n. 2, p. 235-255, 1994.

MENEZES, R. do A.; SILVA, R. B. da; LINHARES, A. Leilões eletrônicos reversos multi atributo: uma abordagem de decisão multicritério aplicada às compras públicas brasileiras. Revista de Administração Contemporânea, v. 11, n. 3, p. 11-33, 2007.

MOREIRA, H. C.; MORAIS, J. M. Compras governamentais: políticas e procedimentos na Organização Mundial de Comércio, União Européia, NAFTA, Estados Unidos e Brasil. CEPAL, 2003.

MUSGRAVE, R. A. Teoria das Finanças Públicas. São Paulo: Atlas, 1994.

NIEBUHR, Joel de Menezes. "Carona” em ata de registro de preços: atentado veemente aos princípios de direito administrativo. Revista Zênite de Licitações e Contratos - ILC. Curitiba, ano 13, n. ${ }^{\circ}$ 143, jan. 2006. Acesso em: 15 maio 2015.

NUNES, A.; DANTAS, L. O. Eficiência do sistema de registro de preços: um estudo de caso no superior tribunal de justiça. Revista Universitas Gestão e TI, v. v.2, p. 1-10, 2012. 
NUNES, J.; LUCENA, R. L.; SILVA, O. G. Vantagens e desvantagens do pregão na gestão de compras no setor público: o caso da Funasa/PB. Revista do Serviço Público. Brasília. Ano 58, n. 2, p. 227-243 Abr/Jun. 2007.

.. Vantagens e desvantagens do pregão na gestão de compras no setor público: o caso da Funasa/PB. Revista do Serviço Público, v. 58, n. 2, p. 227-243, 2014.

PACHECO, R.S. Proposta de reforma do aparelho do Estado do Brasil: novas ideias estão no lugar. In: PETRUCCI, Vera e SCHWARS, Letícia (Org.). Administração pública gerencial: a reforma de 1995: ensaios sobre a reforma administrativa brasileira no limiar do século XXI. Brasília: UnB/ENAP, 1999. 303 p. ISBN 8523005447.

PEREIRA JUNIOR, J. T. DOTTI, M. R. Políticas Públicas nas licitações e contratações administrativas. $2^{\mathrm{a}}$ ed. ver. atual. e ampl. Belo Horizonte: Fórum 2012.

PLATT NETO, O. A. et al. Publicidade e Transparência das Contas Públicas: obrigatoriedade e abrangência desses princípios na administração pública brasileira. In: Congresso USP de Controladoria e Contabilidade, 5 out. 2005. São Paulo: USP, 2005. 12 p.

PONTE, J. P. Estudos de caso em Educação Matemática. Lisboa: CIEDE, 2006

REIS, P. S. de M. O carona no sistema de registro de preços. Revista Zênite de Licitações e Contratos; (ILC). v. 16, n. 167, p. 36-43, jan. 2008.

RIANI, F. Economia do Setor Público: uma Abordagem Introdutória. 3. a ed., Atlas, São Paulo. 1997.

SANCHES, O. M. Dicionário de orçamento, planejamento e áreas afins. 2. ed. atual. e ampl. Brasília: OMS, 2004. 393 p.

O Ciclo Orçamentário: Uma Reavaliação à Luz da Constituição de 1988, In: Giacomoni, J.; Pagnussat, J. L. Planejamento e Orçamento Governamental, 2007, v.1, p. 187-217.

SANTOS, A. R. dos. Metodologia científica: a construção do conhecimento. 7. ed. Rio de Janeiro: Lamparina Editora, 2007. 
SILVA, S. de S. e. Os princípios orçamentários. Rio de Janeiro: Fundação Getúlio Vargas, 1962. $52 \mathrm{p}$.

SILVA, J. A. Orçamento-programa no Brasil. São Paulo: Revista dos Tribunais, 1973. 388 p.

SILVEIRA, F. de A. Análise dos resultados da implantação da ferramenta de pregão eletrônico nas contratações da administração pública - Estudo de Caso do IFRJ. Rio de Janeiro, Universidade do Grande Rio, Dissertação, 127 f, 2012.

VILHENA, R.; HIRLE, A. L. C. Gestão de compras e qualidade do gasto público: a experiência de Minas Gerais com o planejamento de compras e a integração da gestão de compras à gestão orçamentária. In: XVII Congresso Internacional do Centro Latinoamericano de Administração para o Desenvolvimento (Clad) sobre a Reforma do Estado e da Administração Pública.2012 Cartagena, Anais....Cartagena, Colômbia. 2012. 


\section{ANEXO}

\section{Anexo A - Total de compras federais no ano 2010.}

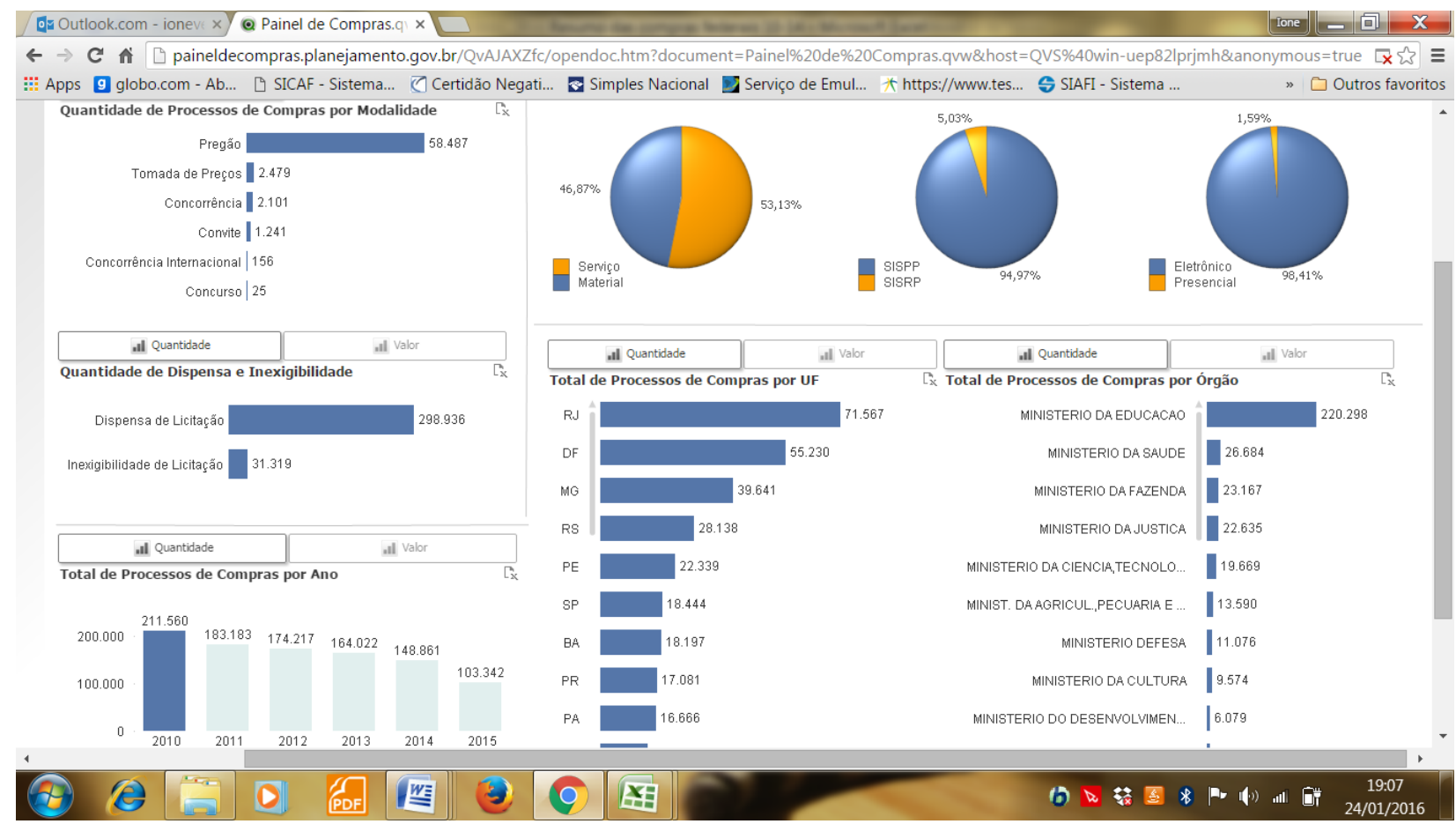

\section{Anexo B - Total de compras federais no ano 2011.}

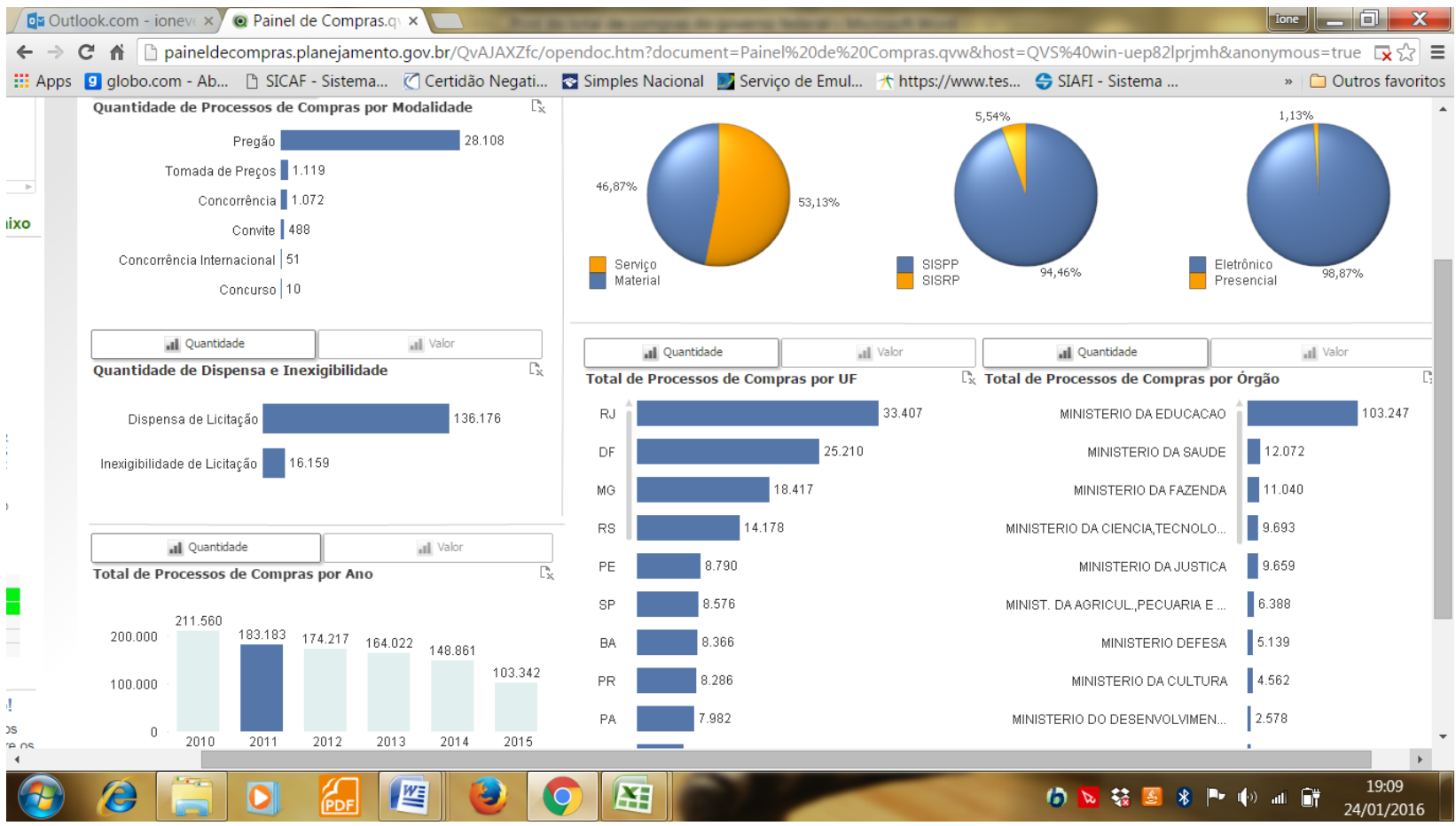




\section{Anexo C - Total de compras federais no ano 2012.}

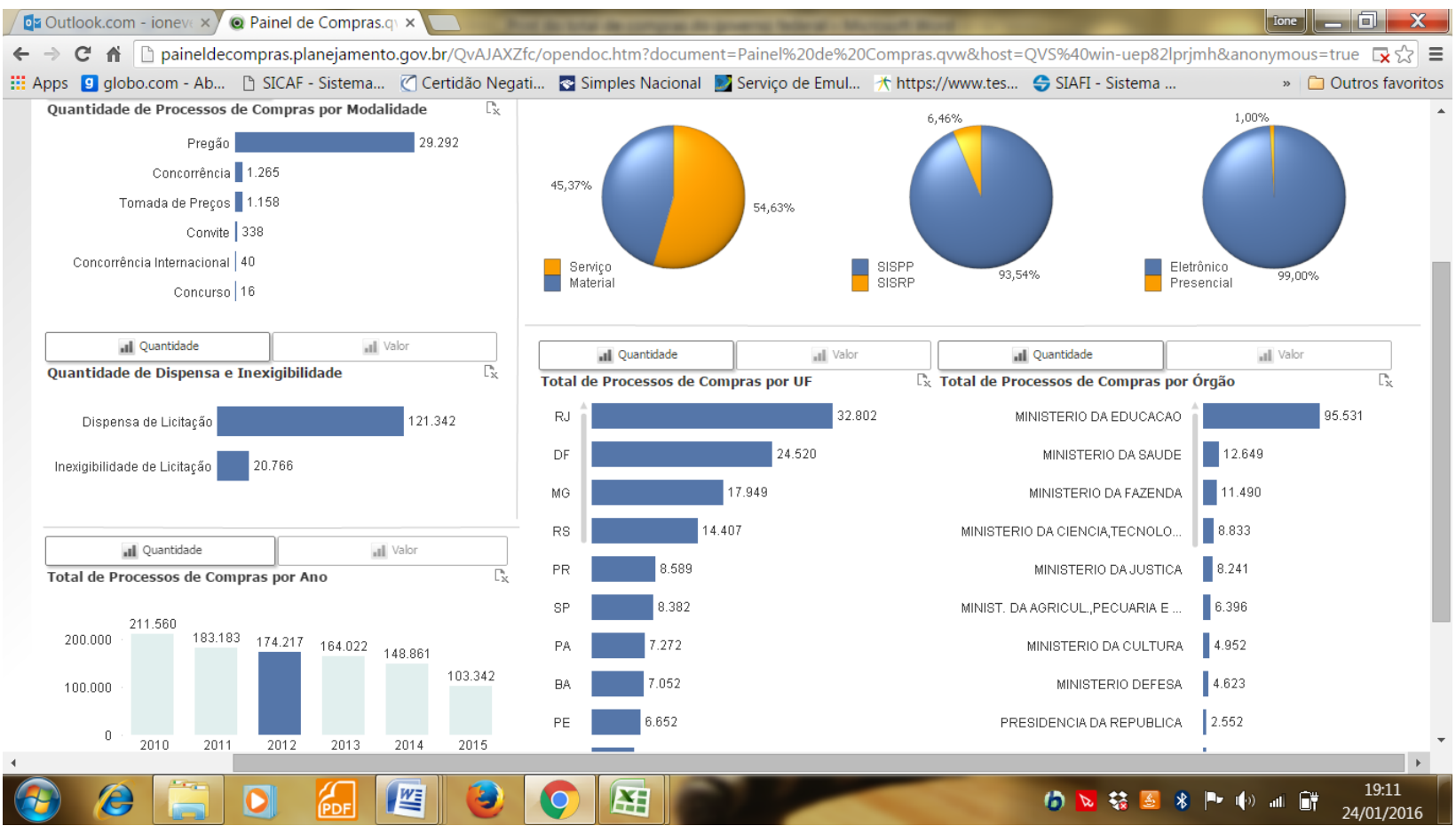

\section{Anexo D - Total de compras federais no ano 2013.}

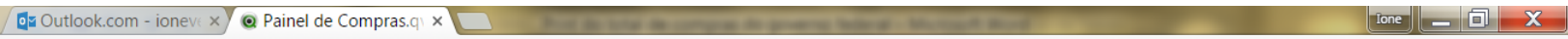

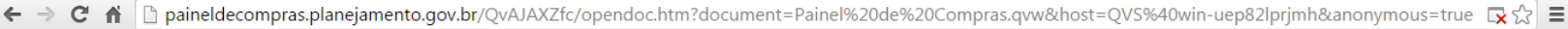

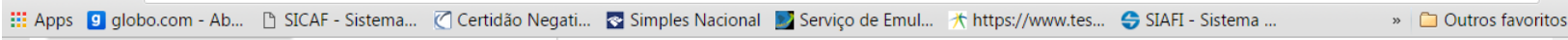
Quantidade de Processos de Compras por Modalidade
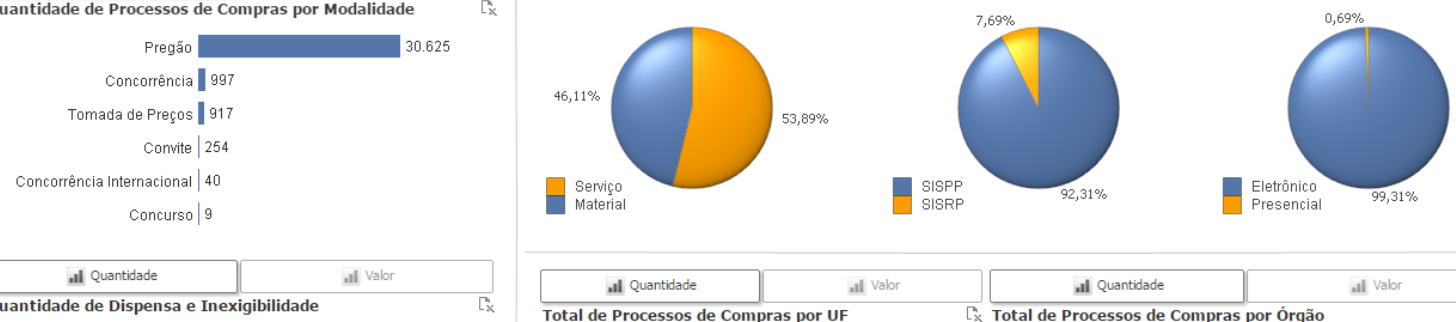

Quantidade de Dispensa e Inexigibilidade

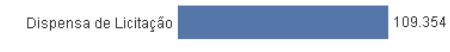

Inexigibilidade de Licitaçẳo $\quad 21.826$
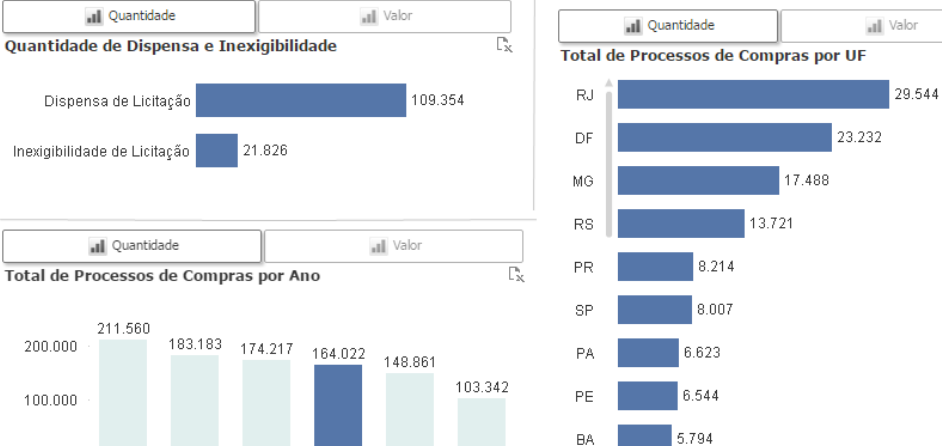

stl Quantidade

Presencia
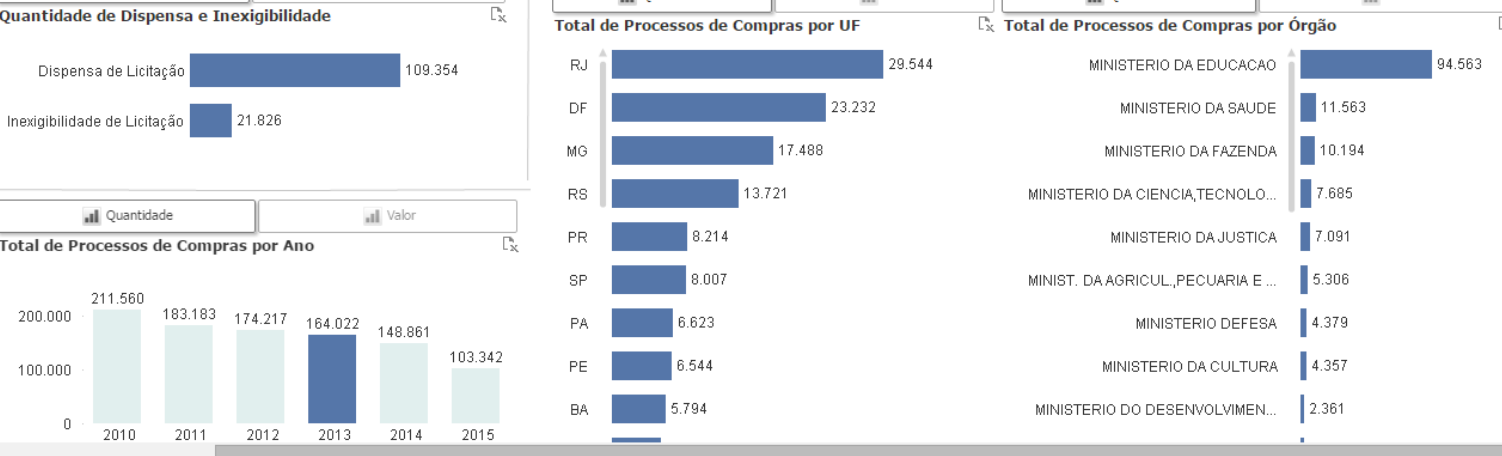


\section{Anexo E - Total de compras federais no ano 2014.}

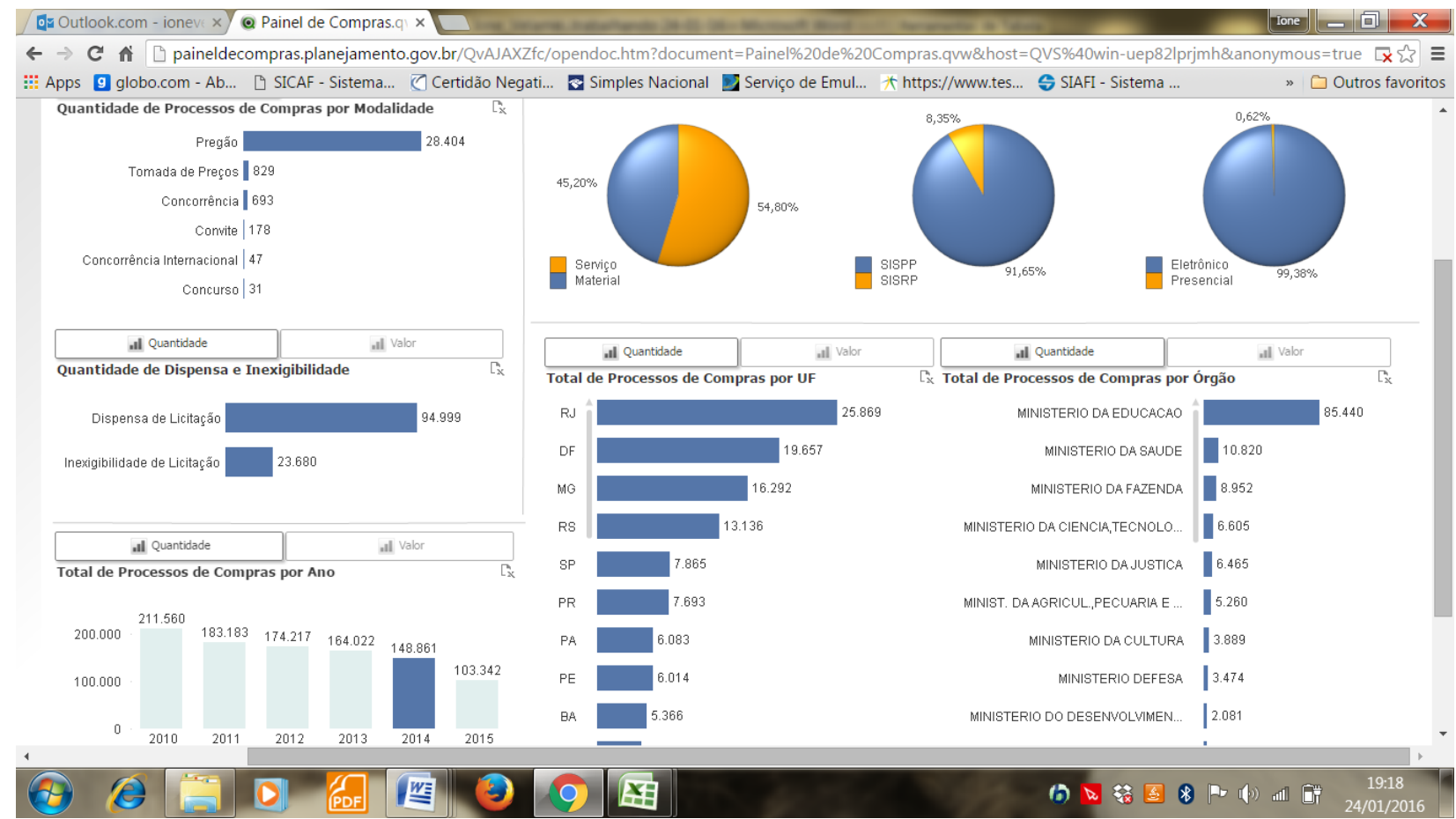

Anexo F - Total de compras IFG - Reitoria no ano 2014.

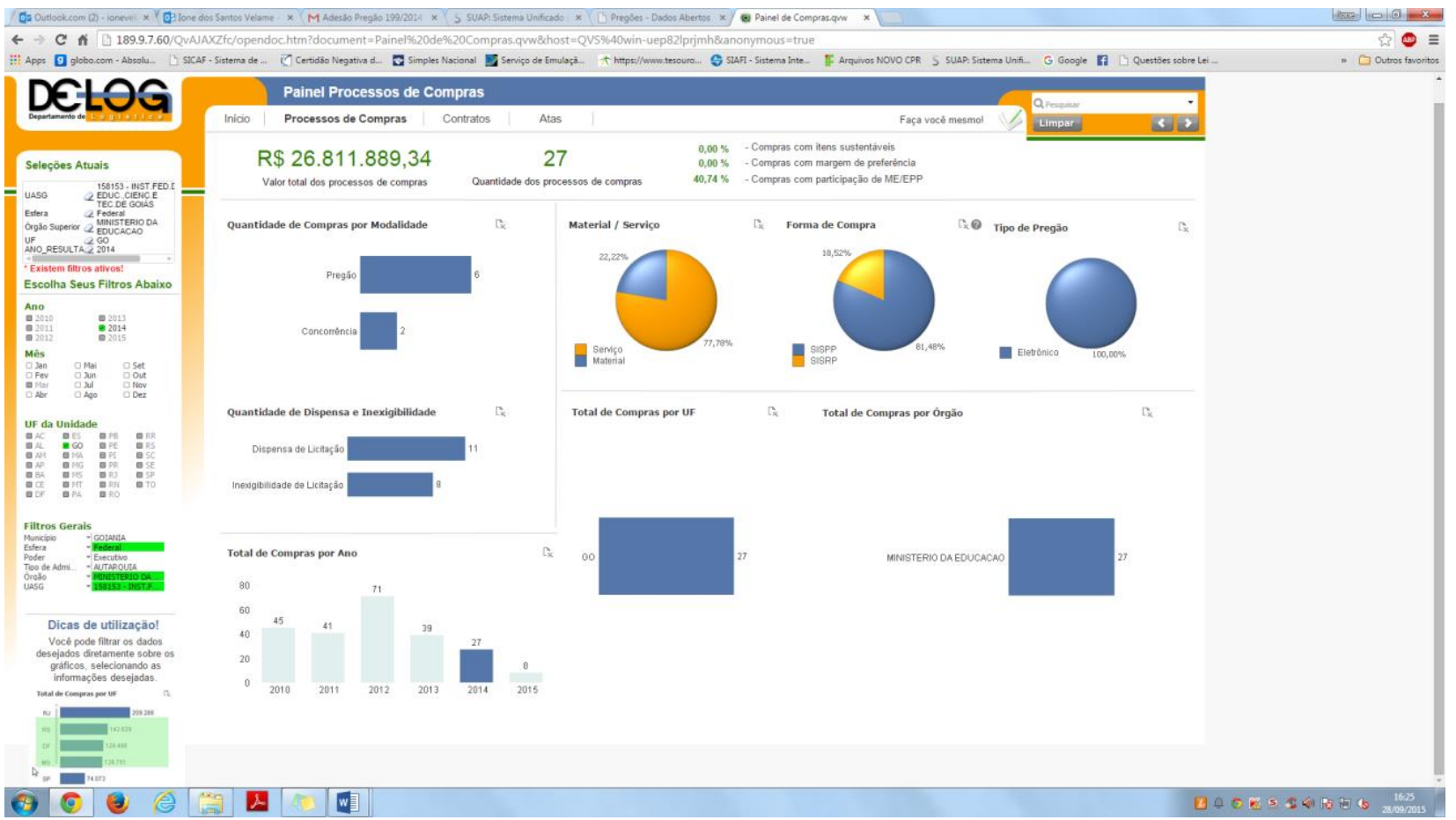


Anexo G - Total de compras IFG - Campus Goiânia no ano 2014.

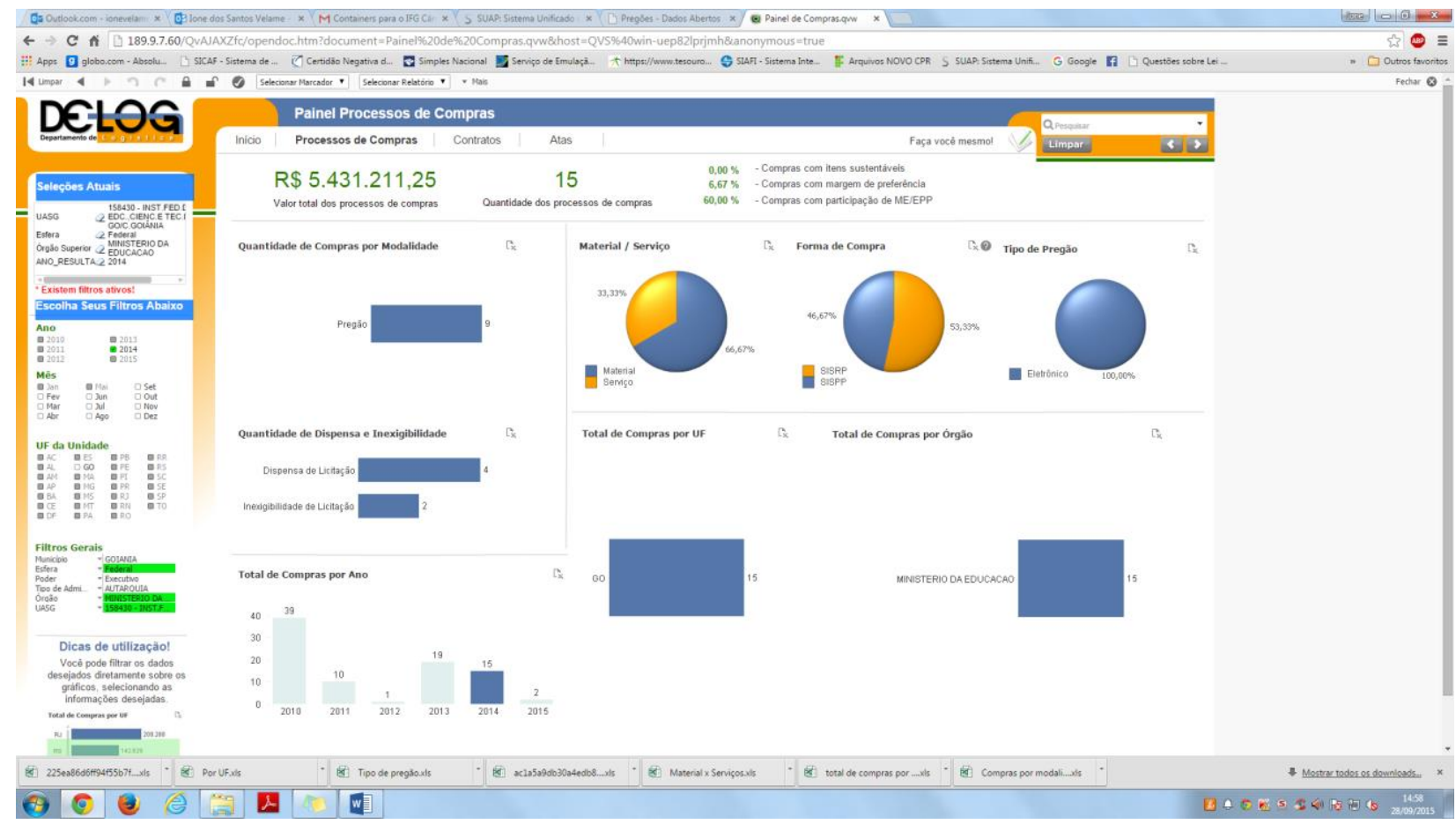

Anexo H - Total de compras IFG - Campus Jataí no ano 2014.

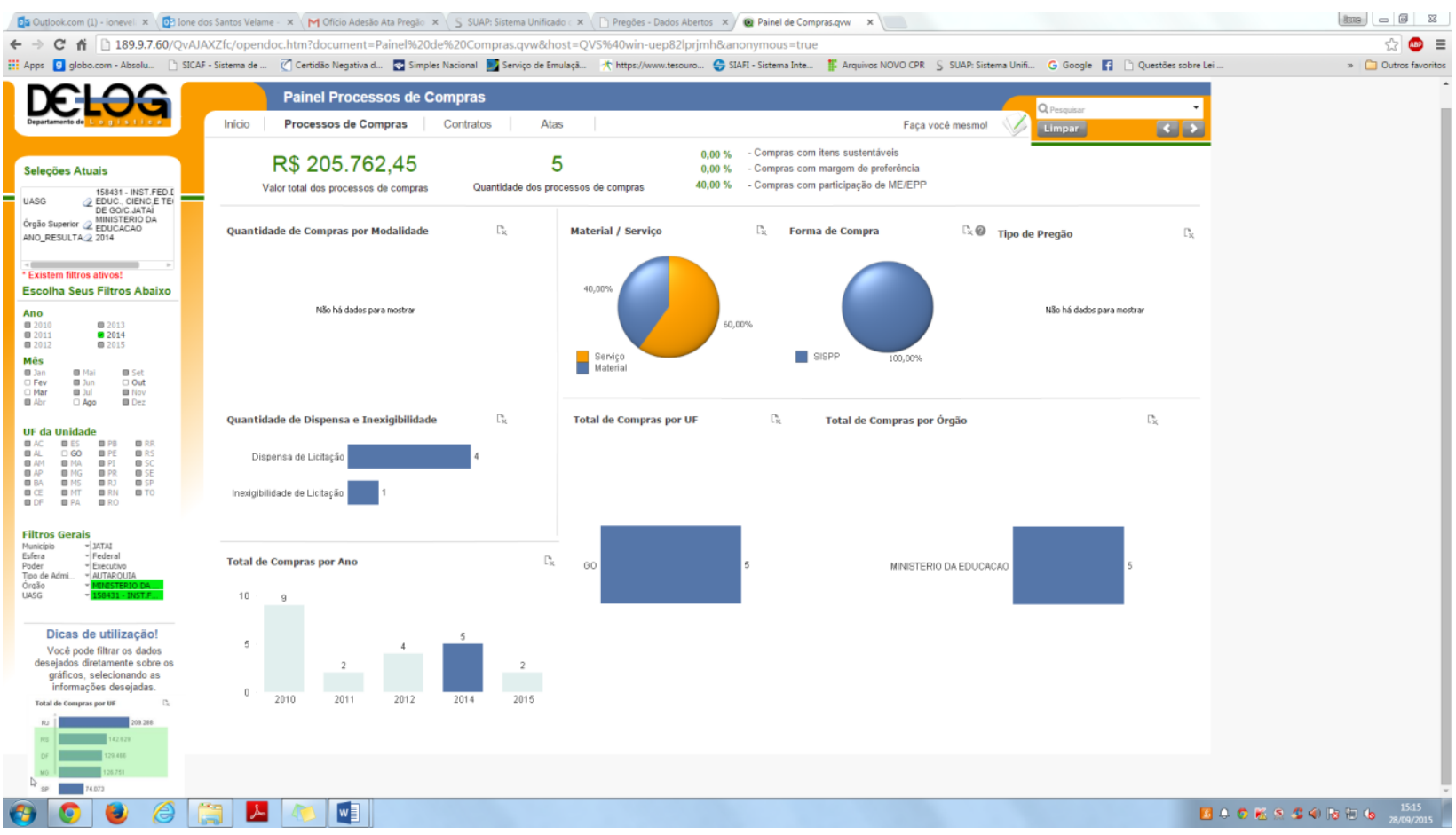


Anexo I - Total de compras IFG - Campus Inhumas no ano 2014.

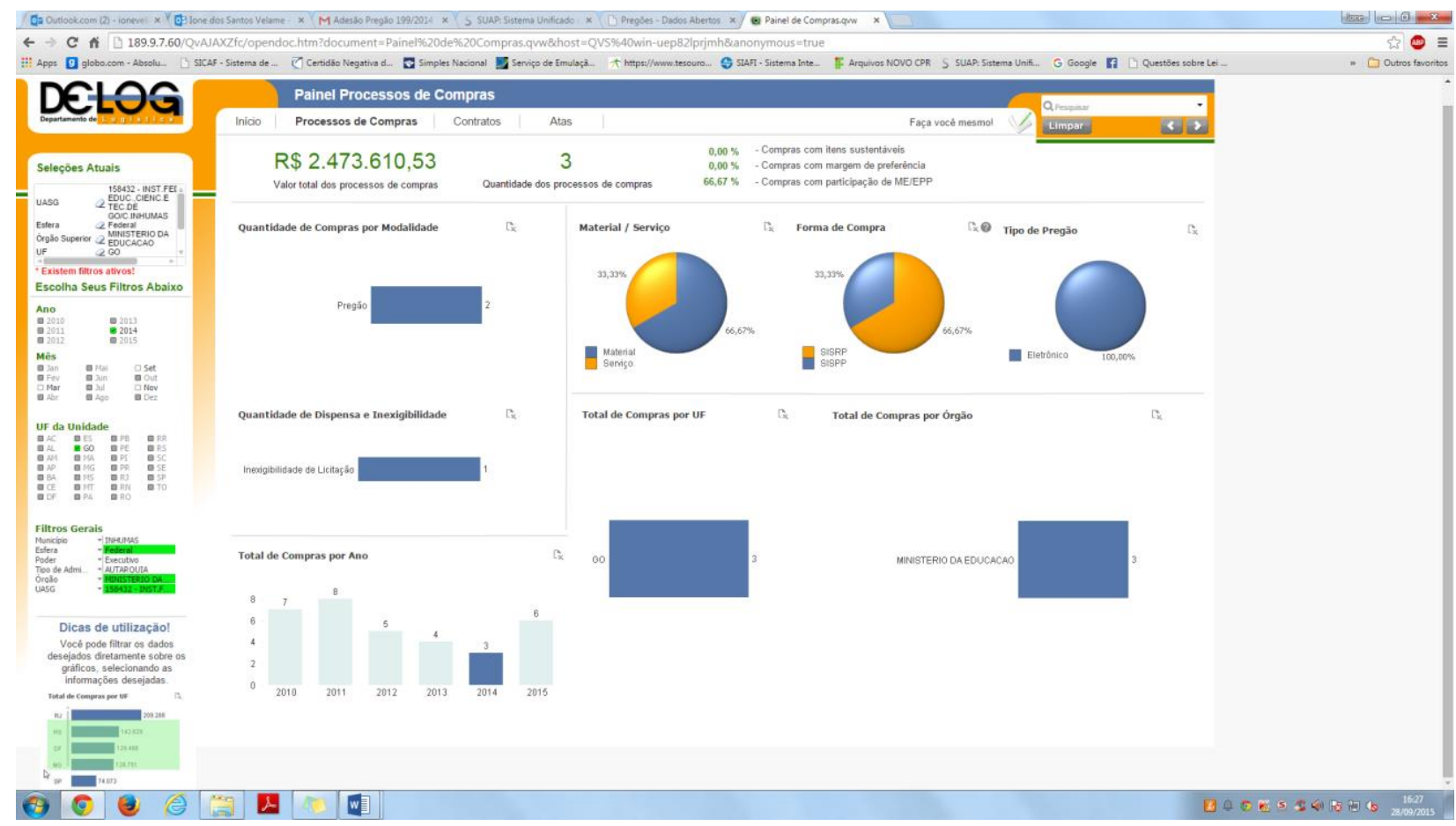

Anexo J - Total de compras IFG - Campus Itumbiara no ano 2014.

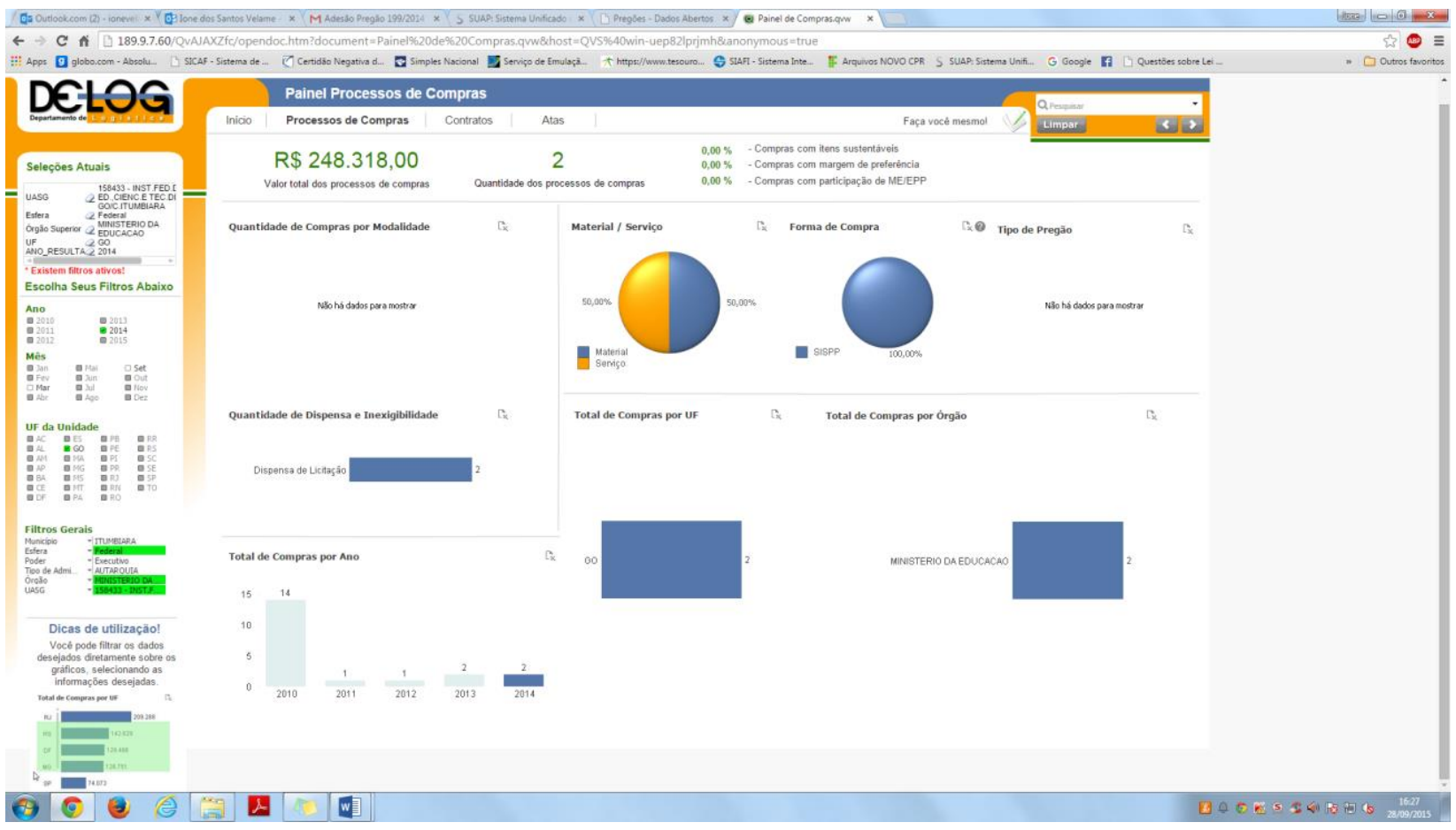


Anexo K - Total de compras IFG - Campus Uruaçú no ano 2014.

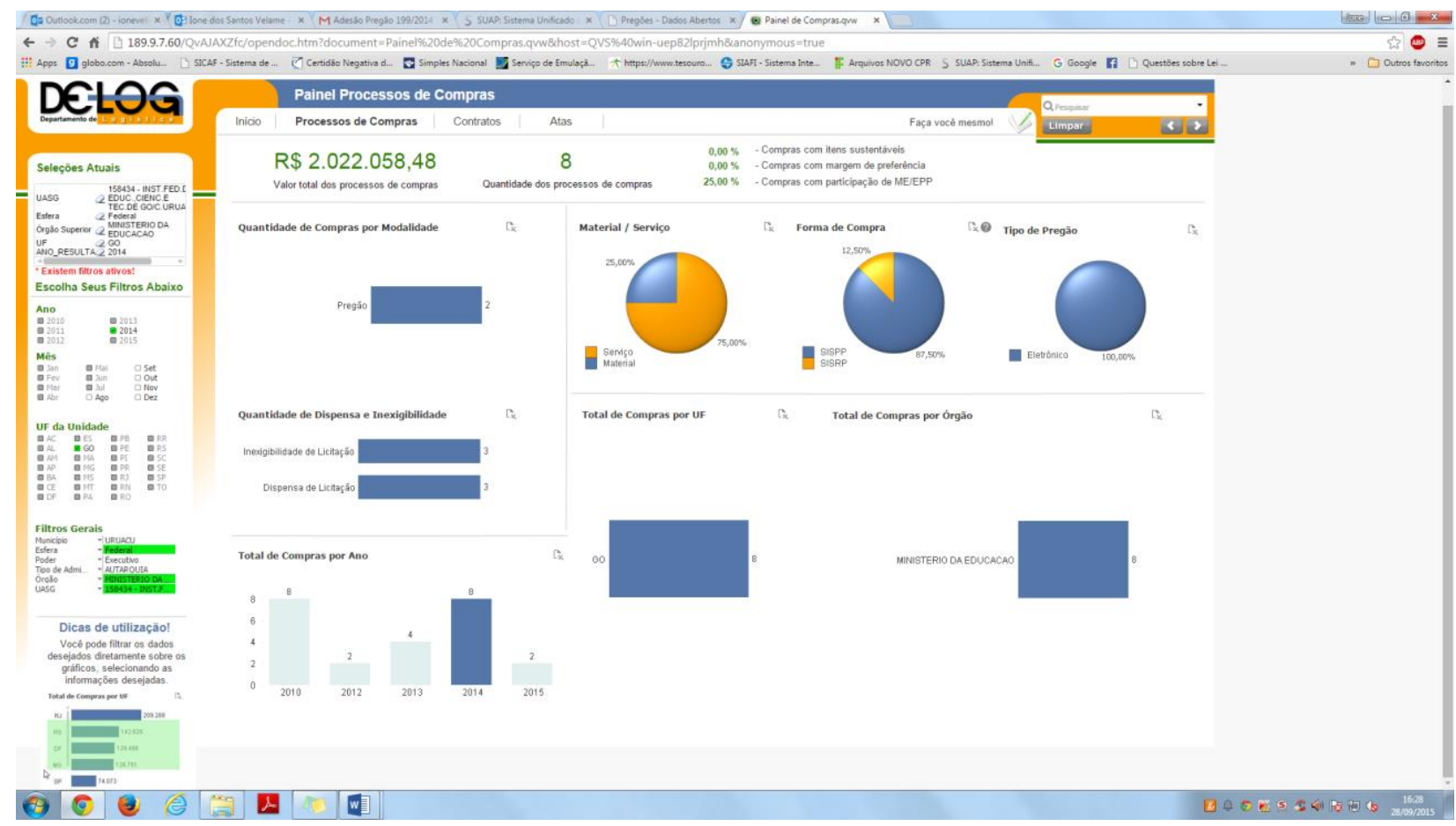

Anexo L - Total de compras IFG - Campus Anápolis no ano 2014.

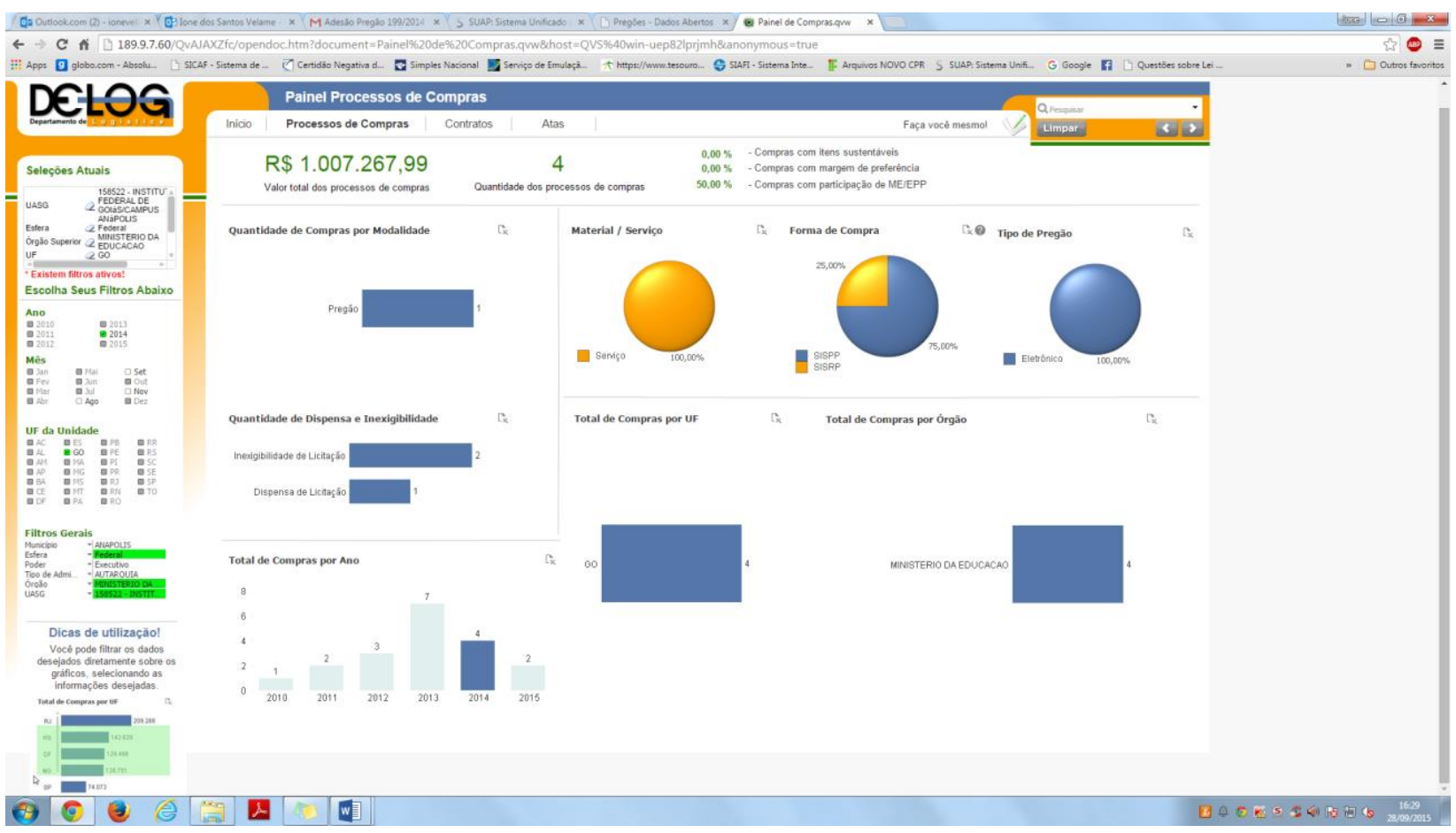


Anexo M - Total de compras IFG - Campus Formosa no ano 2014.

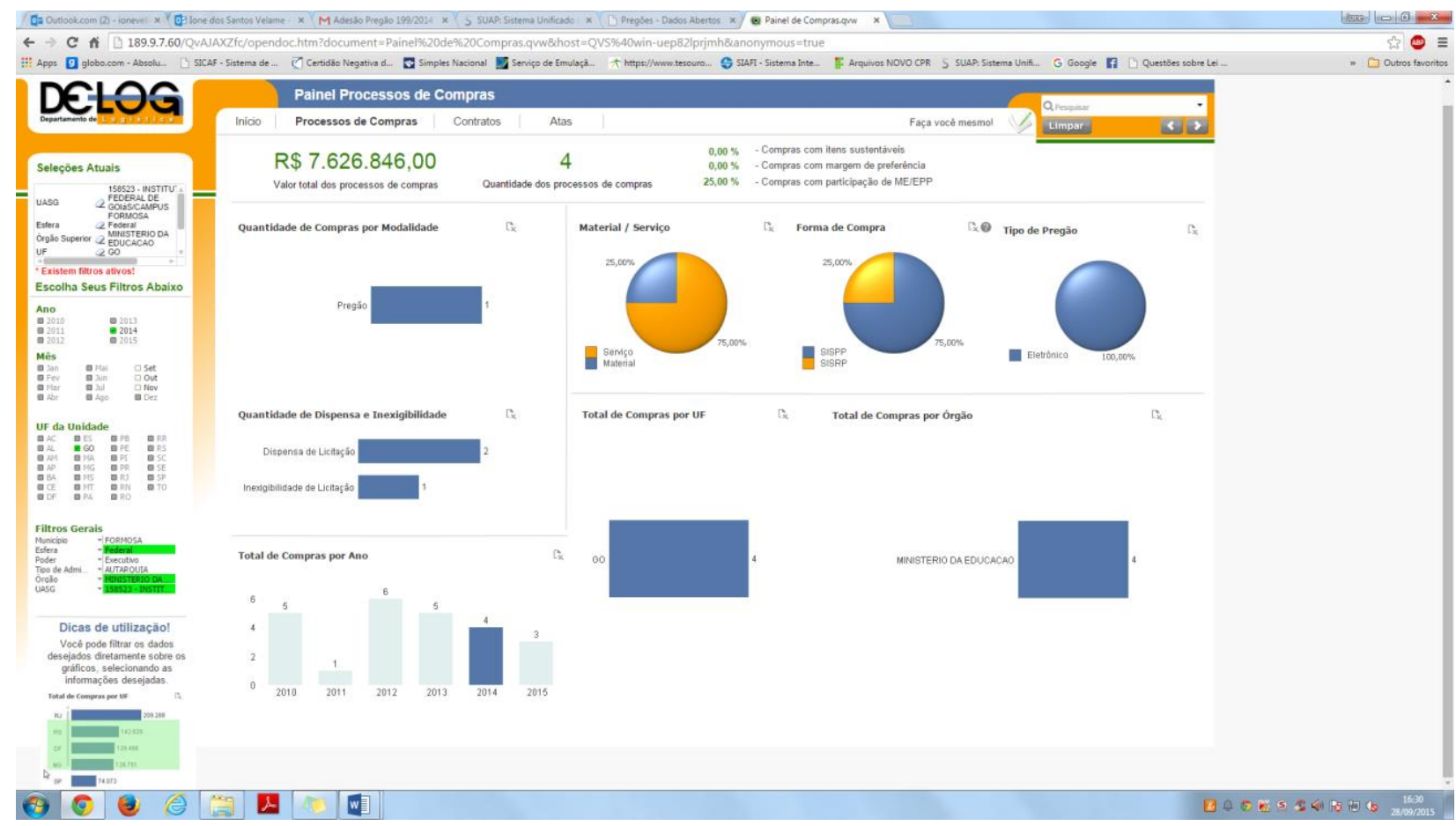

Anexo N - Total de compras IFG - Campus Luziânia no ano 2014.

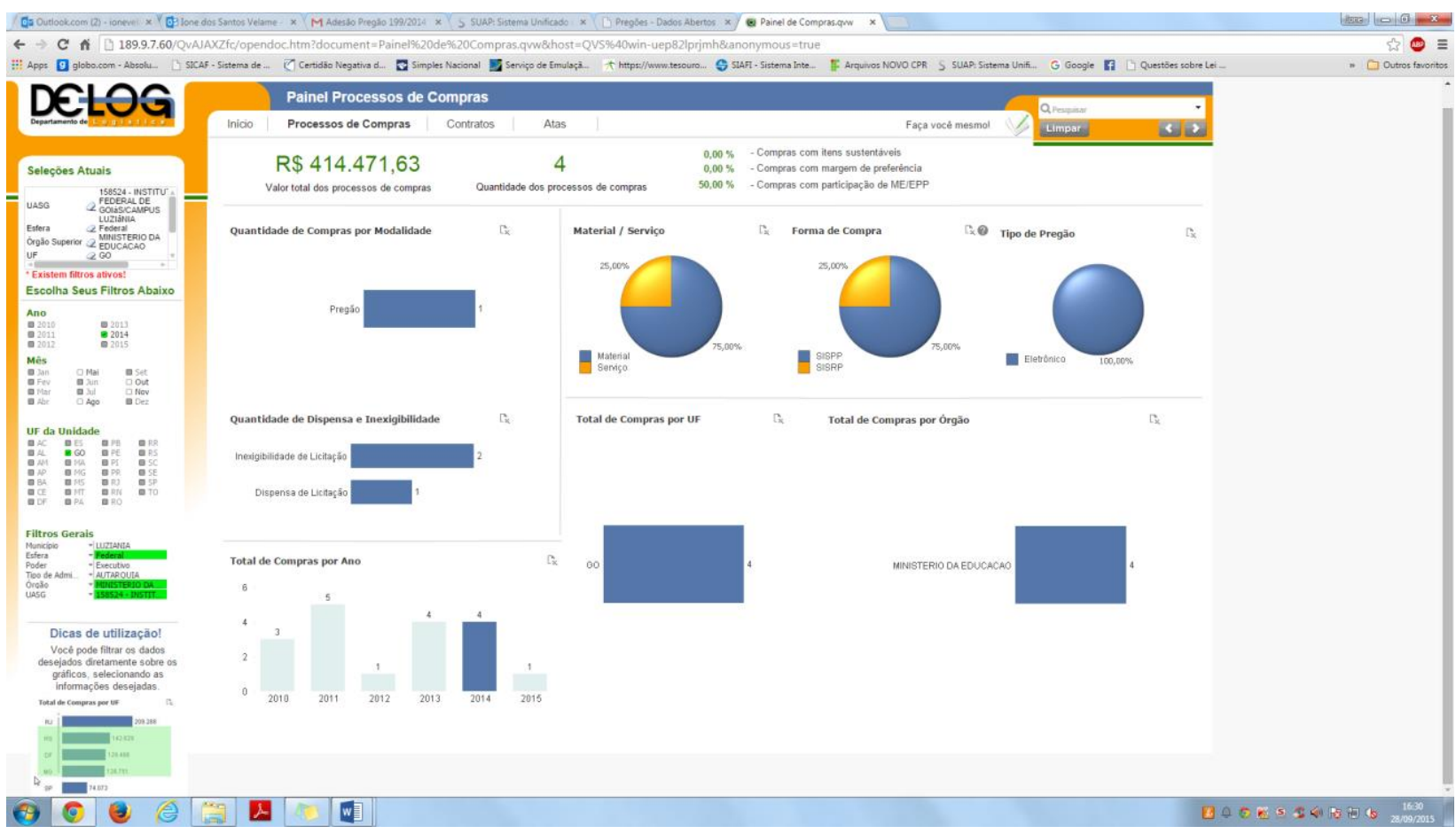


Anexo O - Total de compras IFG - Campus Aparecida de Goiânia no ano 2014.

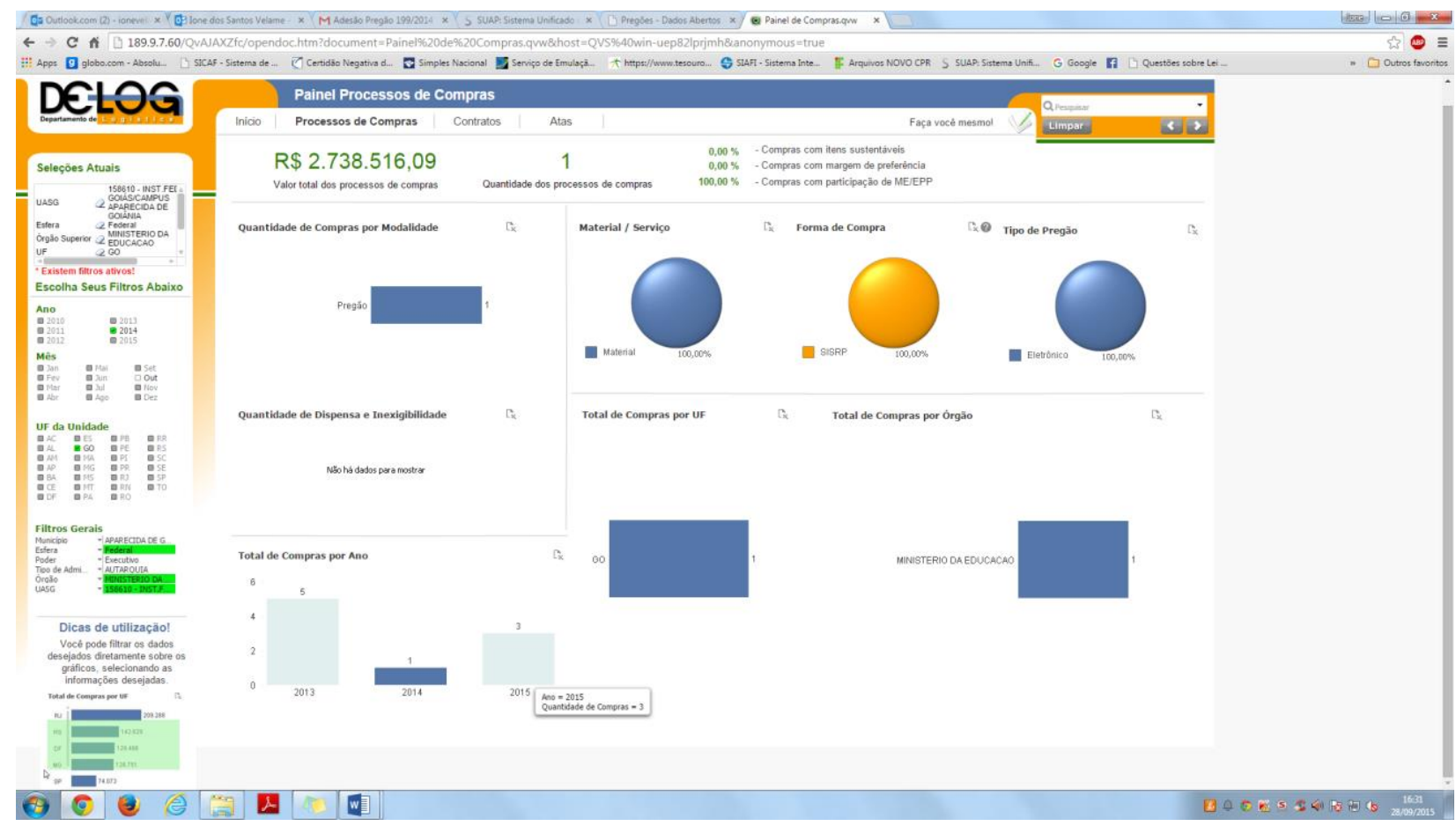

Anexo P - Total de compras IFG - Campus Cidade de Goiás no ano 2014.

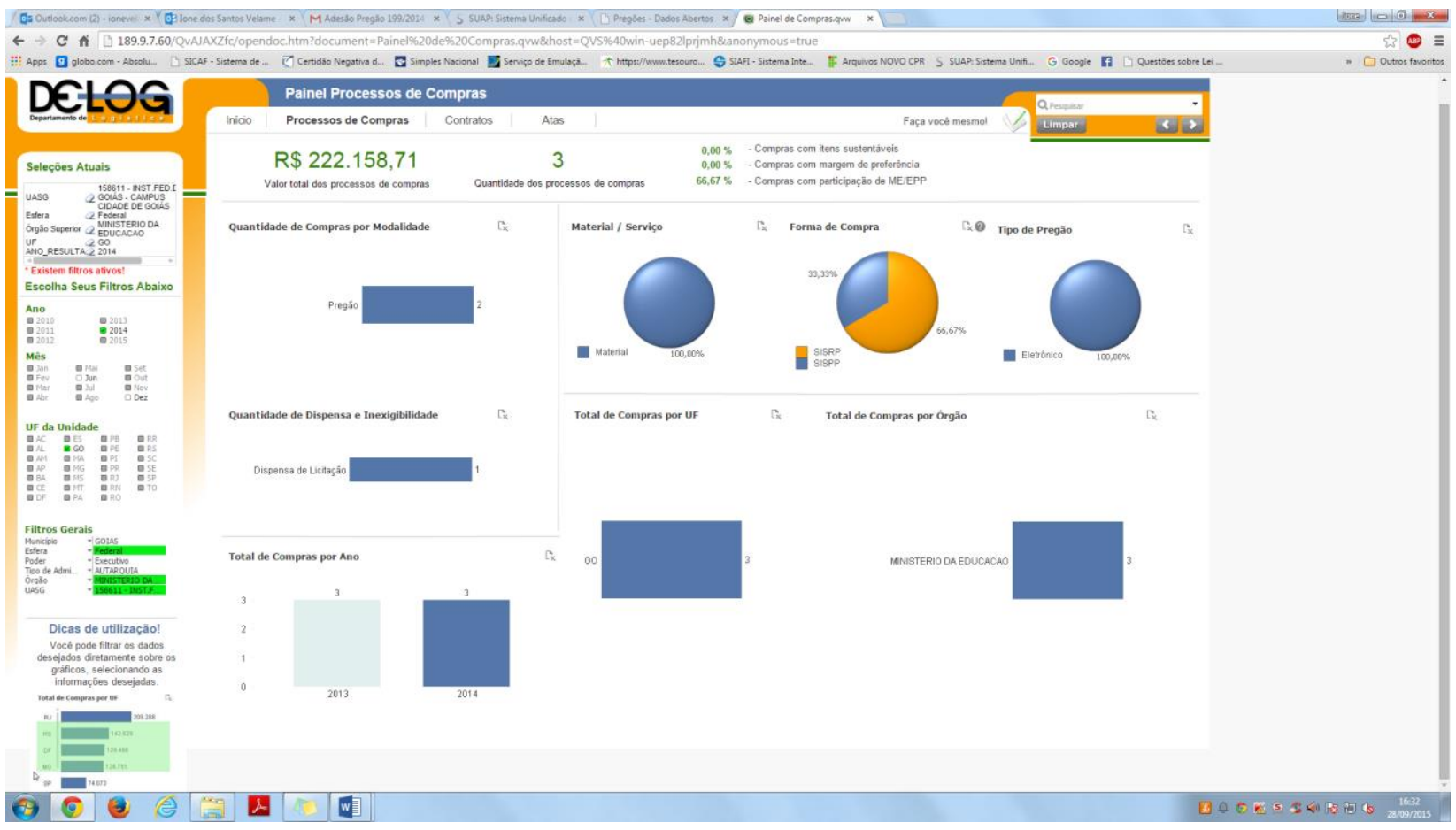




\section{Anexo Q - Total de compras IFGoiano - Reitoria no ano 2014.}

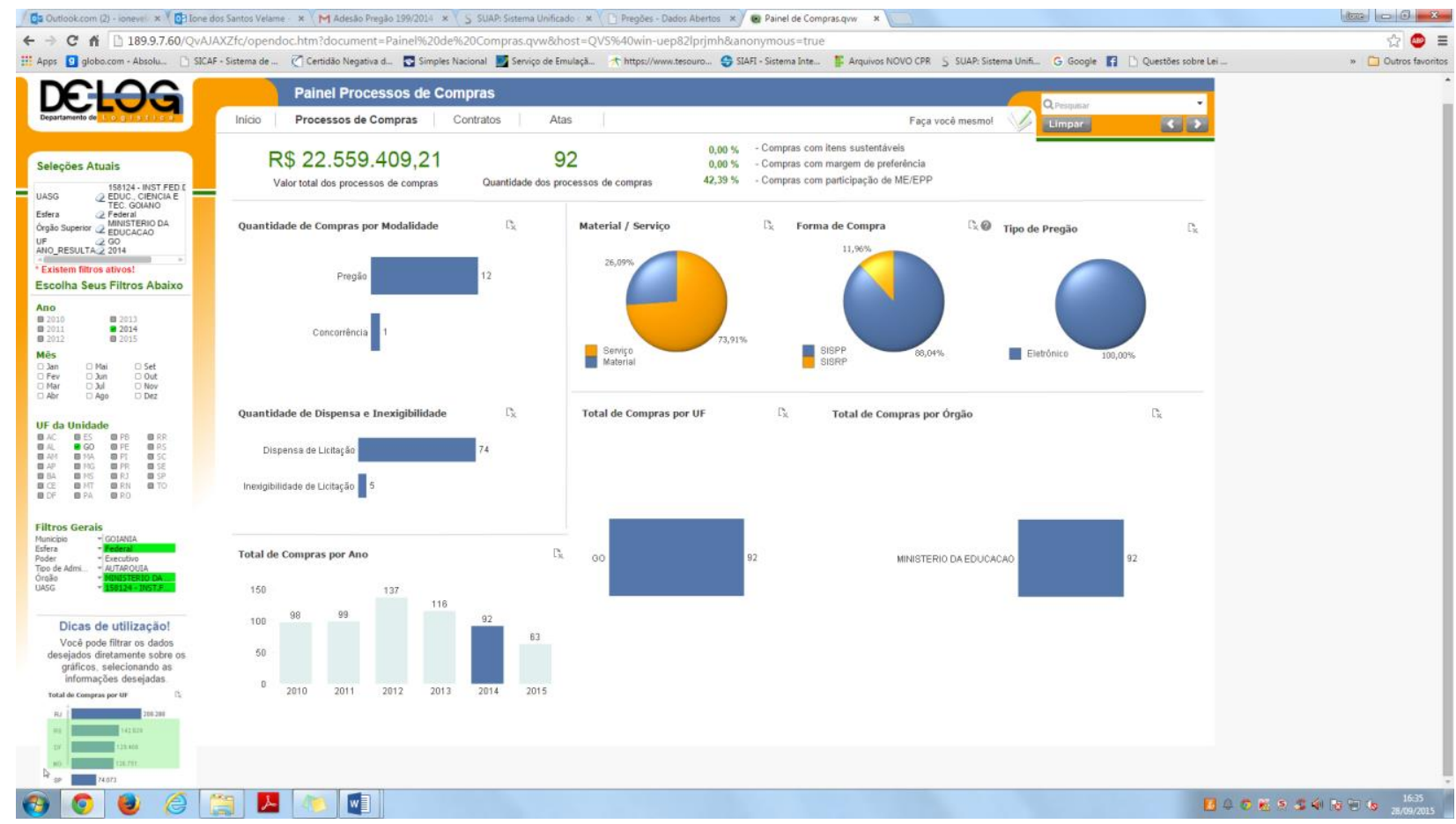

Anexo R - Total de compras IFGoiano - Rio Verde no ano 2014.

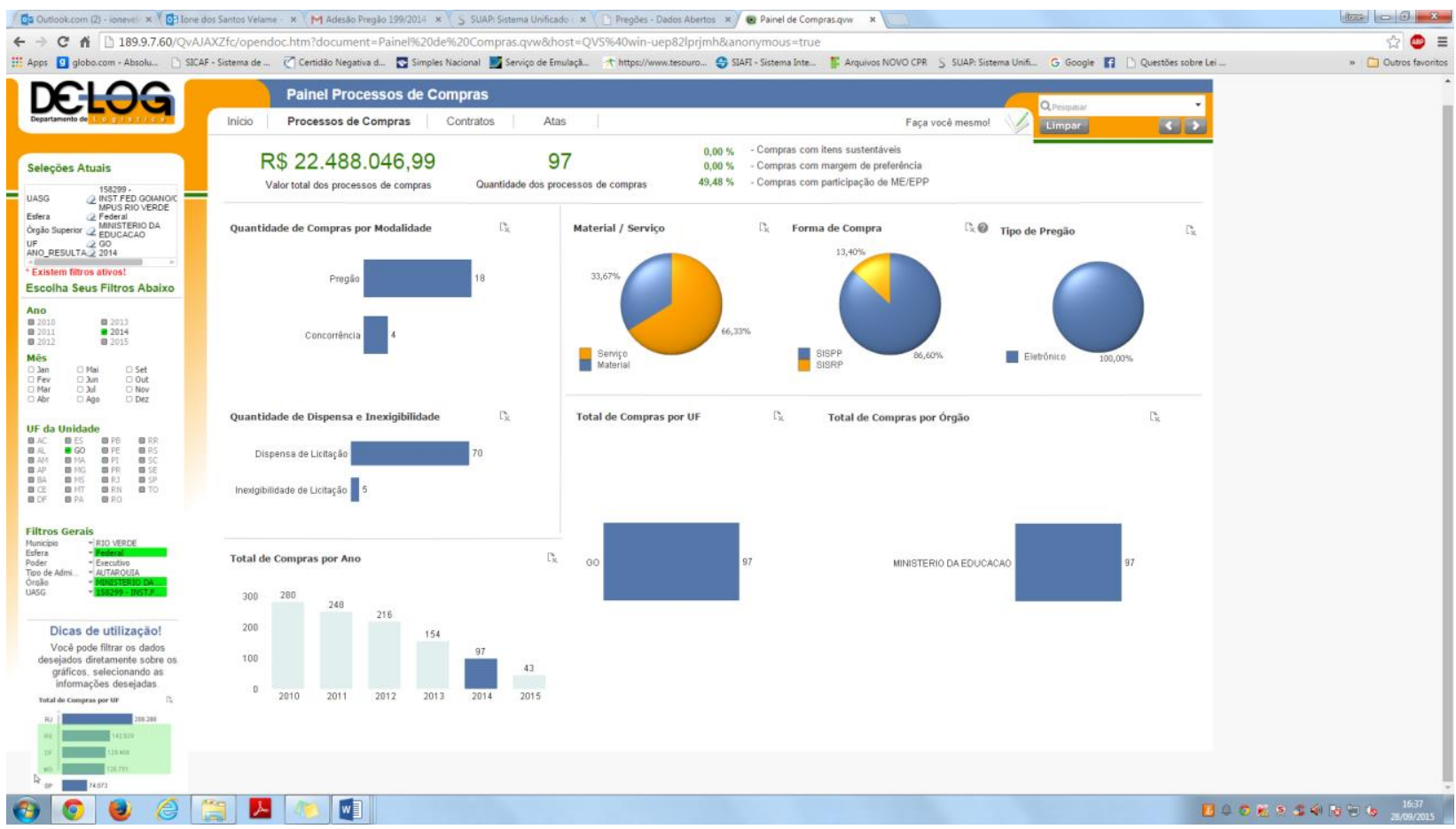


Anexo S - Total de compras IFGoiano - Morrinhos no ano 2014.

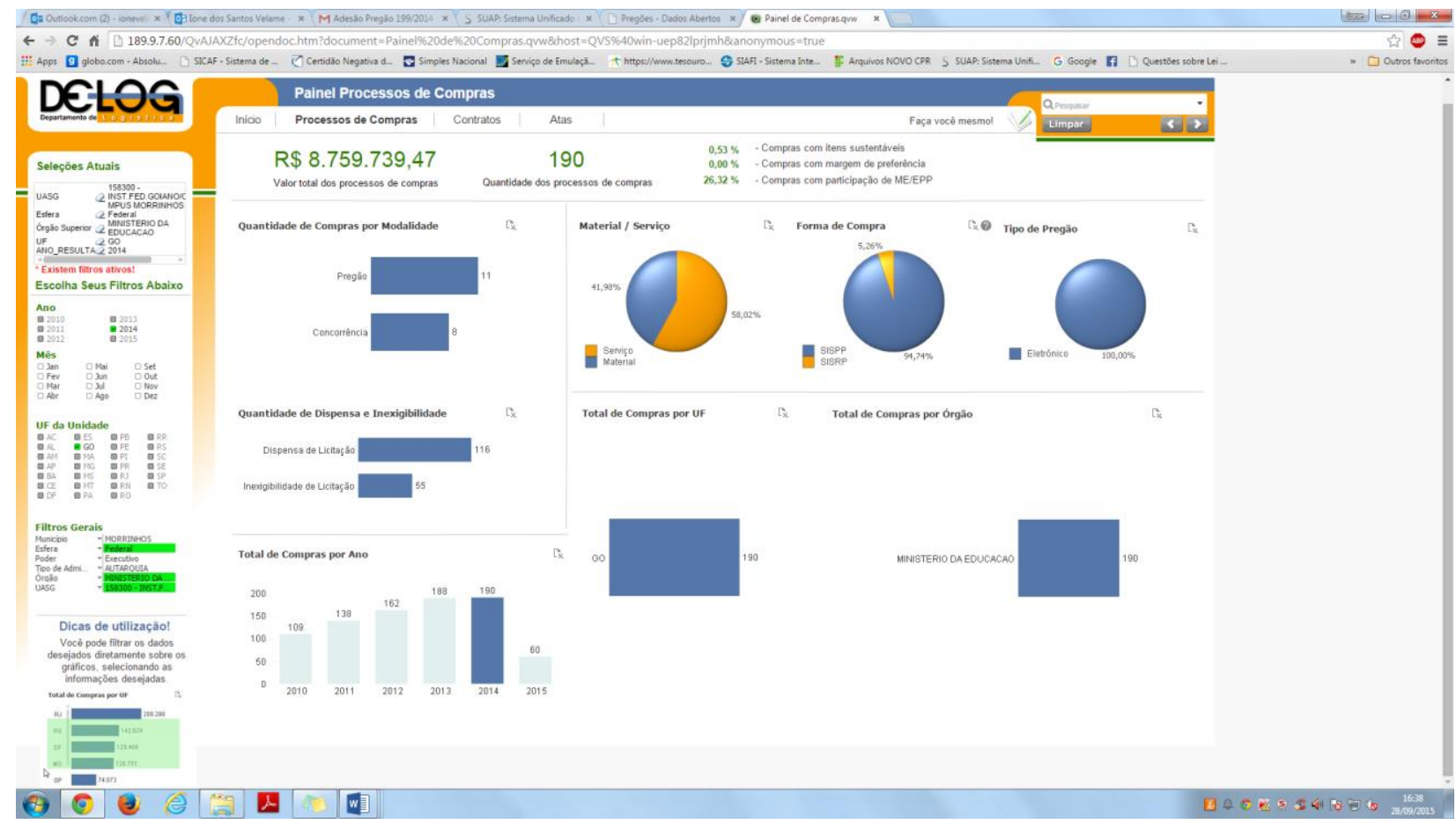

Anexo T - Total de compras IFGoiano - Ceres no ano 2014.

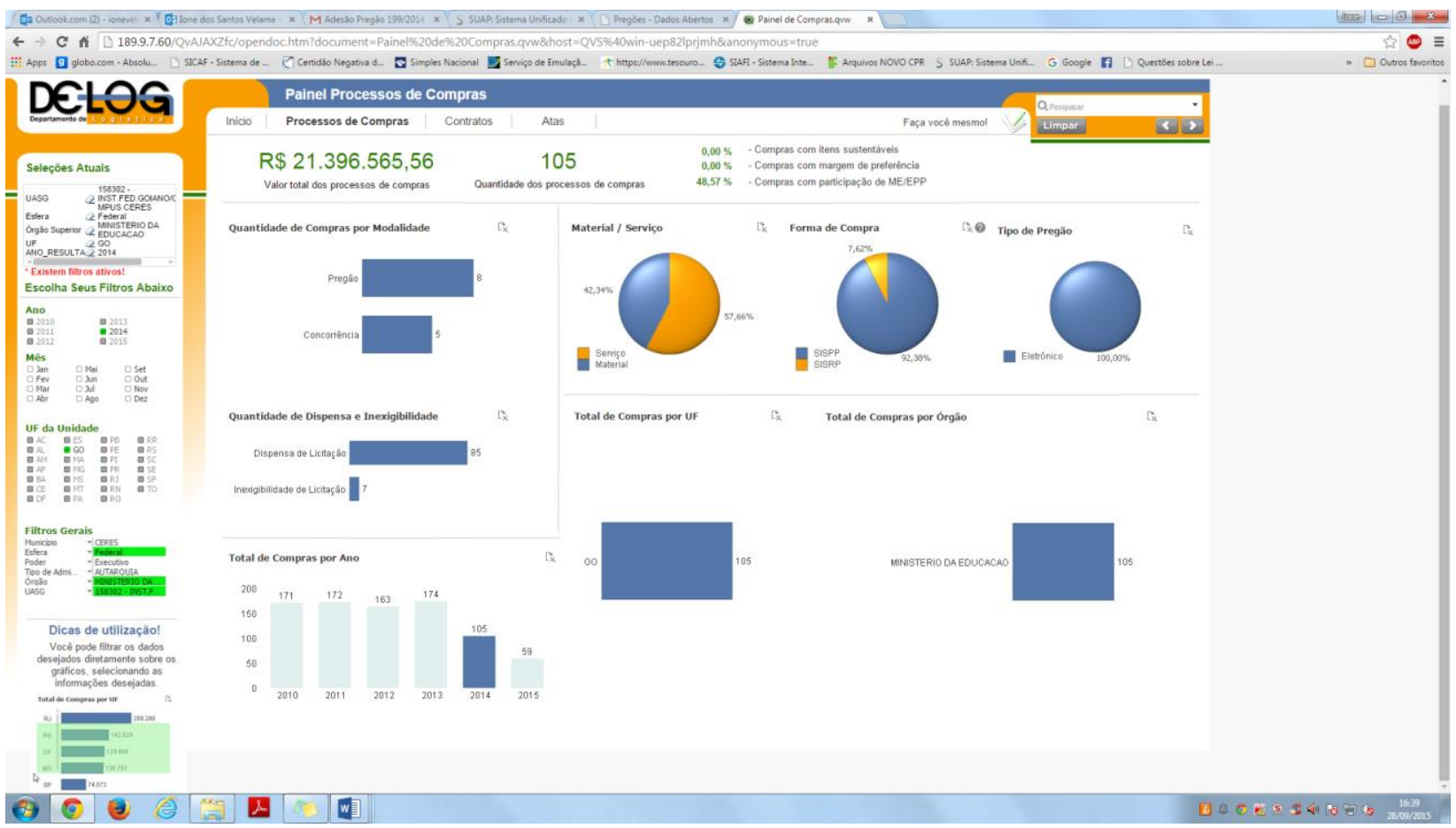


Anexo U - Total de compras IFGoiano - Iporá no ano 2014.

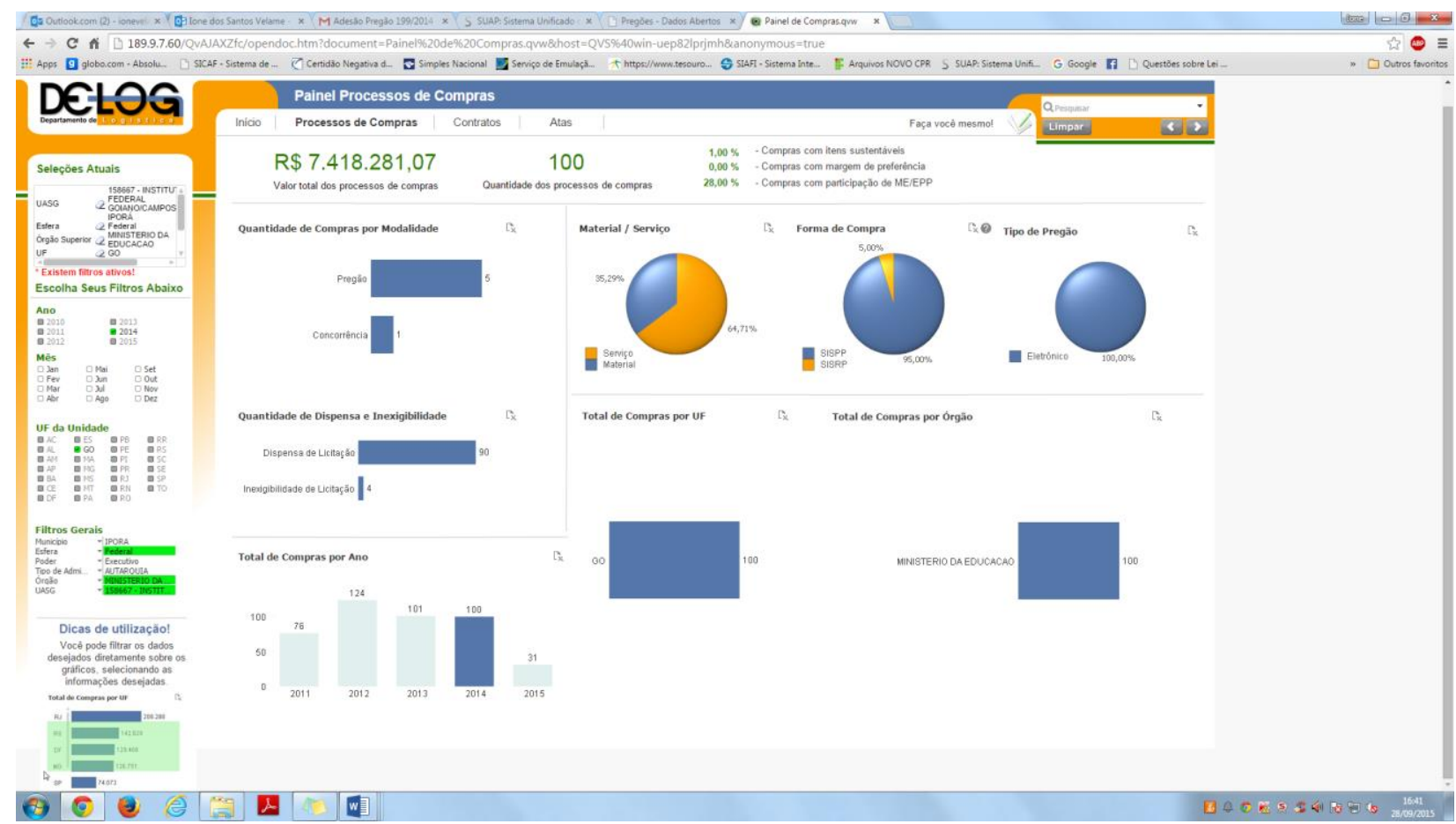

Anexo V - Total de compras do IFB no ano 2014.

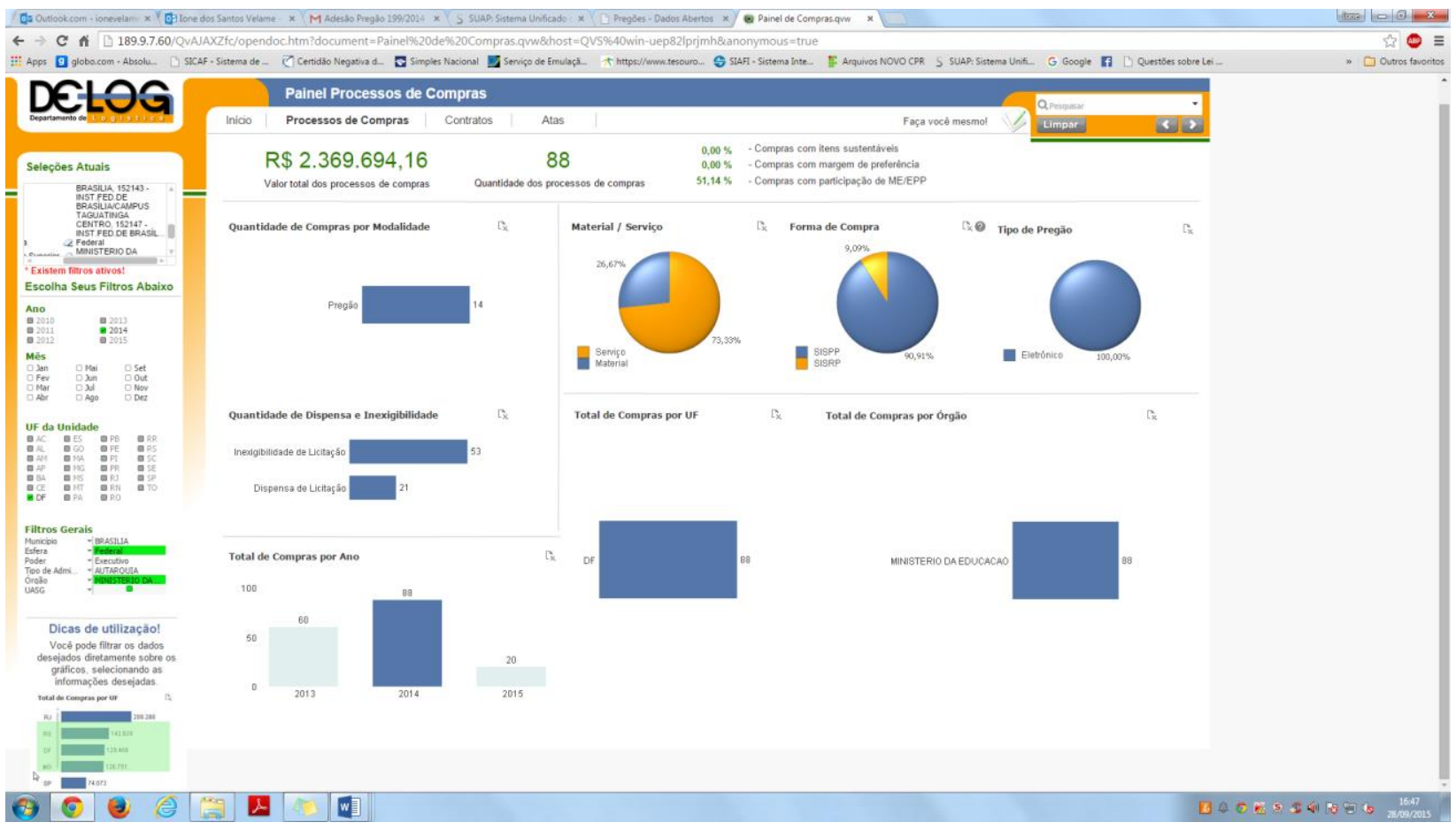


Anexo X - Total de compras do IFMT no ano 2014.

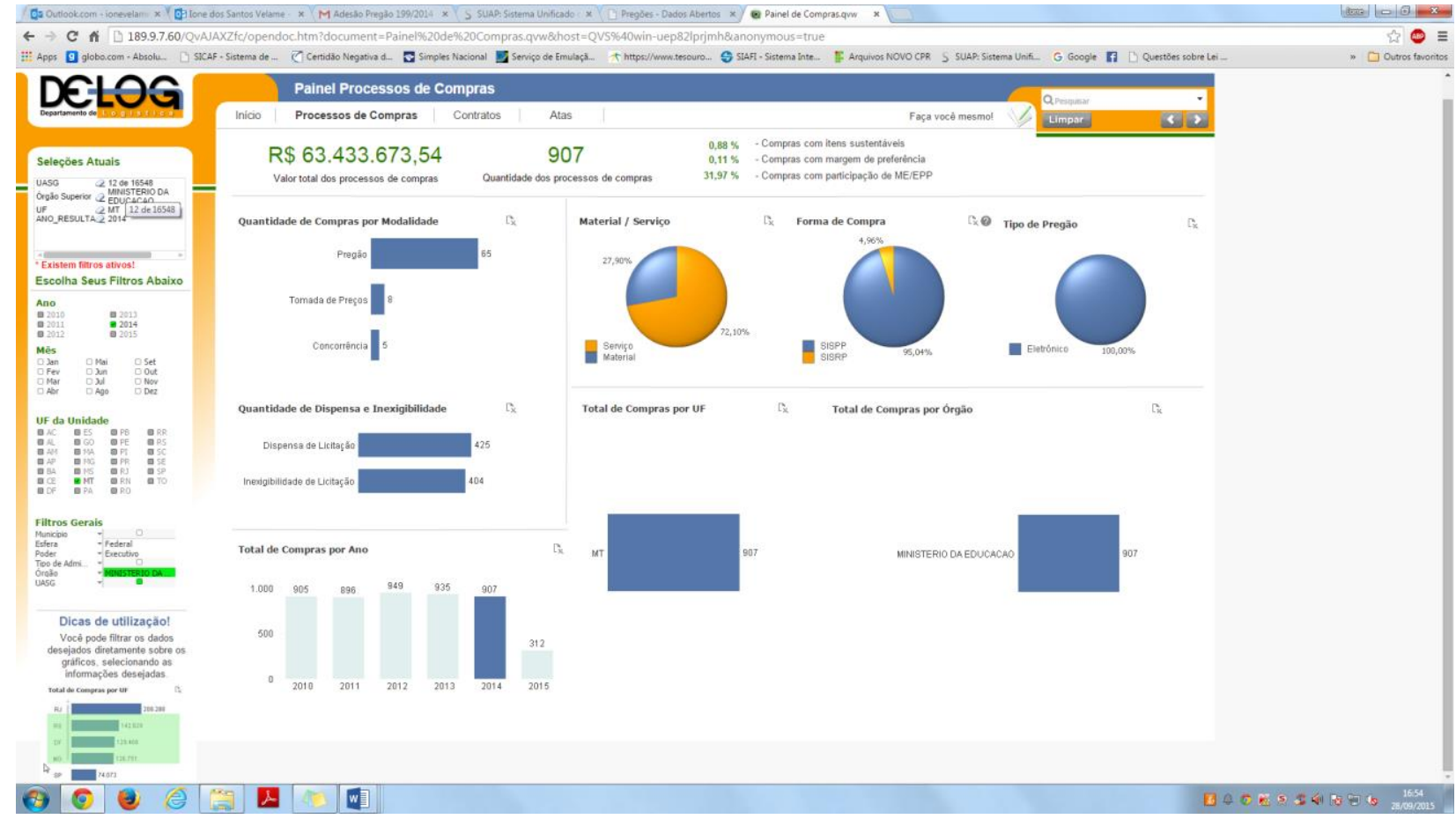

Anexo Z - Total de compras do IFMS no ano 2014.

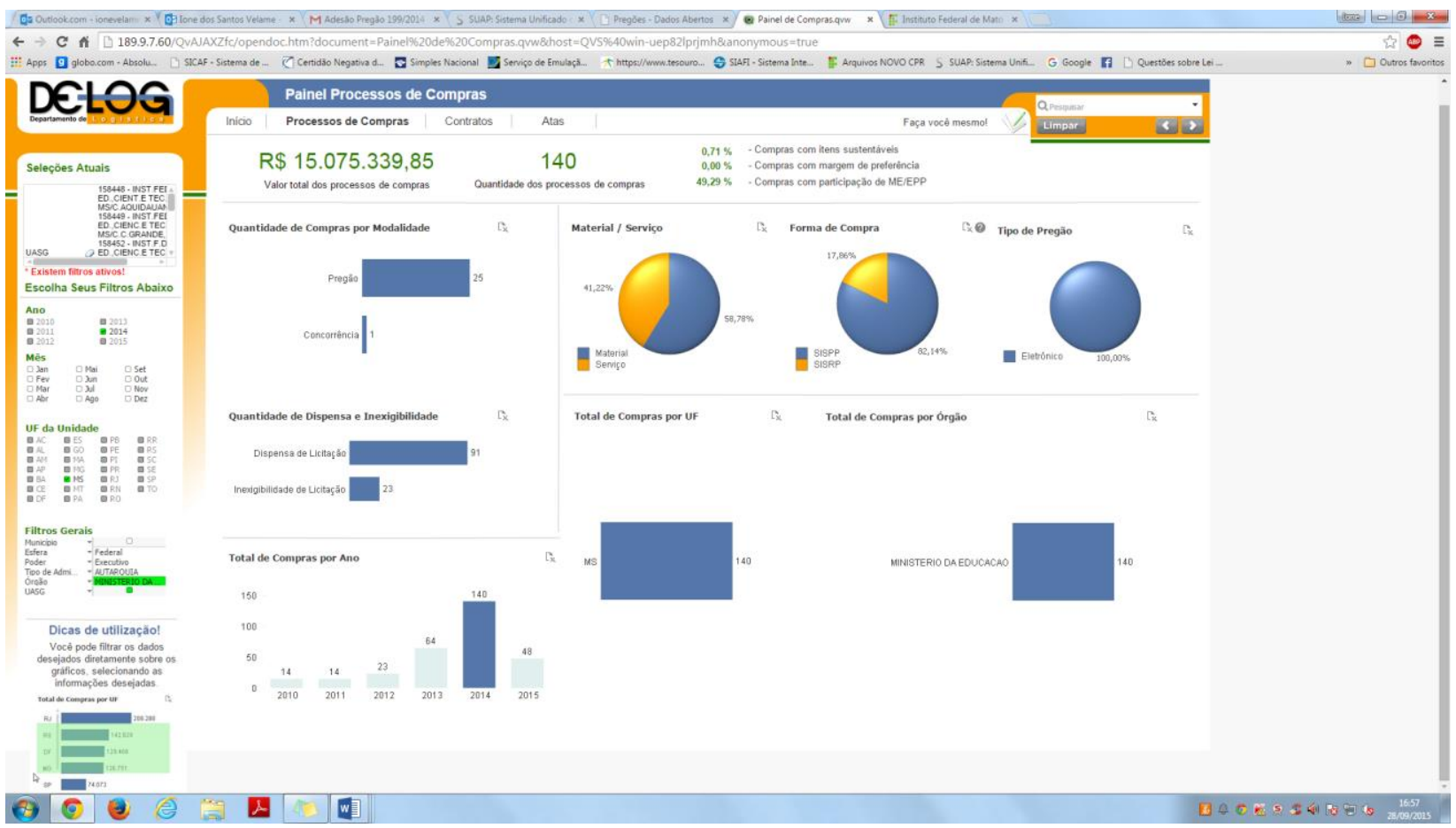

